\title{
Grenada: 2007 Article IV Consultation-Staff Report; Staff Supplement; and Public Information Notice on the Executive Board Discussion
}

Under Article IV of the IMF's Articles of Agreement, the IMF holds bilateral discussions with members, usually every year. In the context of the 2007 Article IV consultation with Grenada, the following documents have been released and are included in this package:

- The staff report for the 2007 Article IV consultation, prepared by a staff team of the IMF, following discussions that ended on July 16, 2007 with the officials of Grenada on economic developments and policies. Based on information available at the time of these discussions, the staff report was completed on September 10, 2007. The views expressed in the staff report are those of the staff team and do not necessarily reflect the views of the Executive Board of the IMF.

- $\quad$ A staff supplement on the joint IMF/World Bank debt sustainability analysis.

- $\quad$ A Public Information Notice (PIN) summarizing the views of the Executive Board as expressed during its September 26, 2007 discussion of the staff report that concluded the Article IV consultation.

The document listed below has been or will be separately released.

Statistical Appendix

The policy of publication of staff reports and other documents allows for the deletion of market-sensitive information.

Copies of this report are available to the public from

International Monetary Fund • Publication Services $70019^{\text {th }}$ Street, N.W. • Washington, D.C. 20431

Telephone: (202) 623-7430 • Telefax: (202) 623-7201

E-mail: publications@imf.org Internet: http://www.imf.org

Price: $\$ 18.00$ a copy

\section{International Monetary Fund}

Washington, D.C. 



\title{
INTERNATIONAL MONETARY FUND
}

\section{GRENADA}

\section{Staff Report for the 2007 Article IV Consultation}

\author{
Prepared by the Staff Representatives for the 2007 Consultation with Grenada
}

Approved by José Fajgenbaum (WHD) and Matthew Fisher (PDR)

September 10, 2007

\section{EXECUTIVE SUMMARY}

Background. Grenada's economy has rebounded after the devastating impact of Hurricanes Ivan and Emily, with the recovery centered on reconstruction and 2007 Cricket World Cup preparations. The economic outlook is favorable, as several major tourism investment projects get underway. Inflation has been subdued. Fiscal performance, however, has been much weaker than programmed in 2006-07, owing to capital expenditure overruns. Public debt reached 125 percent of GDP at end-2006, leaving little room for maneuver in the event of exogenous shocks.

Fund relations. The last Article IV consultation was concluded in July 2005. On April 17, 2006, the Executive Board approved a PRGF arrangement for 90 percent of quota. The program went off track relatively soon thereafter, owing to fiscal slippages, the slow pace of structural reforms, and the need to address the longstanding issue of an unregulated bank. The 2007 Article IV consultation had been delayed while discussions focused on measures needed to complete the PRGF review.

Discussions centered on the key challenges, progress with which could revitalize the PRGF program:

- Restoring fiscal and debt sustainability. The authorities recognized that corrective action was needed to compensate for the recent fiscal slippages. But the high debt levels call for an even stronger fiscal effort, including the use of all divestment proceeds to pay down expensive debt rather than to finance capital expenditure. This would allow the government to reach its debt-to-GDP target of 60 percent by 2017 , rather than 2025 under current policies. The authorities found it difficult to scale back capital expenditure as much as recommended by staff, preferring to use half of divestment proceeds for project financing.

- Safeguarding financial sector stability. Grenada's financial system weathered well the impact of the hurricanes, and Grenada recently established a single regulatory agency to supervise nonbank financial institutions. The authorities shared the mission's concerns about the continued operation of an unregulated bank and insurance companies' deposit-taking activities. They are exploring options to supervise the bank, and intend to conduct a thorough investigation of insurance companies' activities.

- Managing vulnerabilities. The government has taken steps to mitigate the risk of natural disasters and to diversify the economic base. Staff highlighted Grenada's vulnerability arising from large government and external financing needs over the foreseeable future.

- Reinvigorating the structural reform agenda. Critical reforms include addressing the issue of the unregulated bank; improving the business environment to sustain competitiveness; reforming the tax concessions regime (although the authorities no longer intend to fully eliminate tax holidays in light of regional competition); introducing a VAT; strengthening the capacity to evaluate and prioritize capital projects; enhancing tax administration; and developing a full-fledged Poverty Reduction Strategy (PRS). 


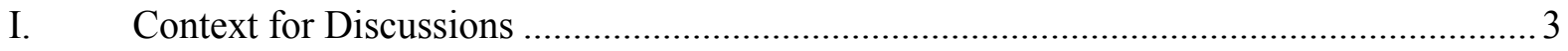

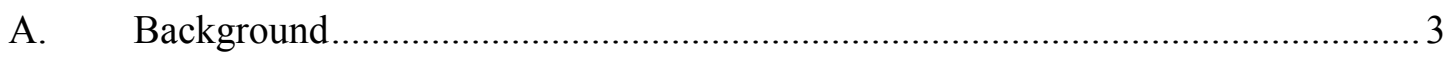

B. Recent Developments and Outlook ............................................................... 5

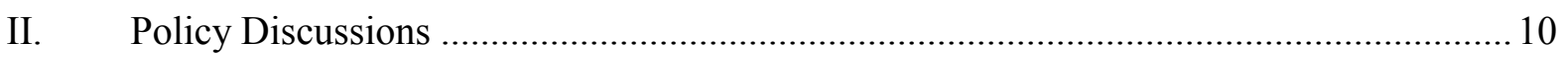

A. Restoring Fiscal and Debt Sustainability ................................................... 10

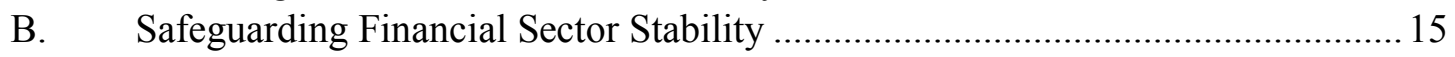

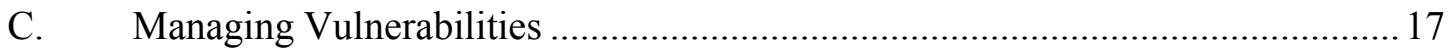

D. Enhancing Competitiveness........................................................................... 19

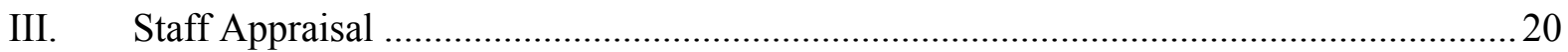

Box

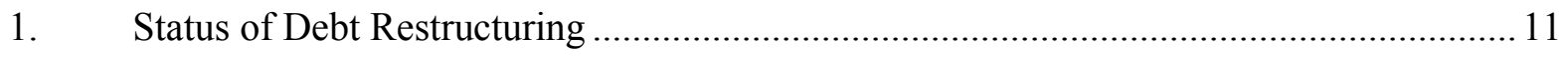

Figures

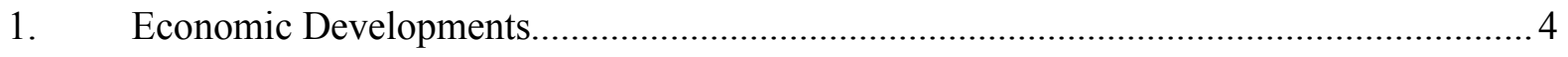

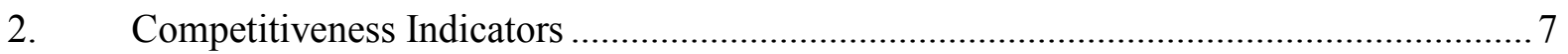

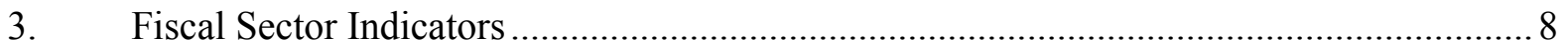

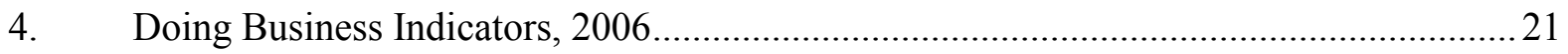

Tables

1. Selected Economic and Financial Indicators, 2003-09............................................. 25

2a. Medium-Term Central Government Finances, Baseline Scenario, 2003-09

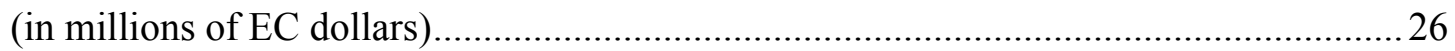

2b. Medium-Term Central Government Finances, Baseline Scenario, 2003-09

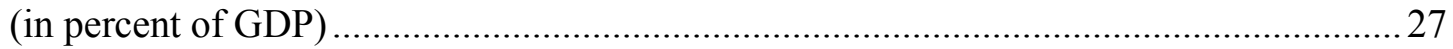

2c. Medium-Term Central Government Finances, Active Scenario, 2003-09

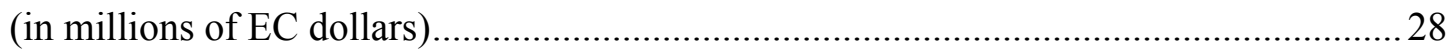

2d. Medium-Term Central Government Finances, Active Scenario, 2003-09

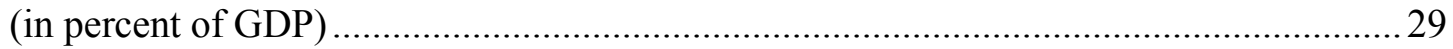

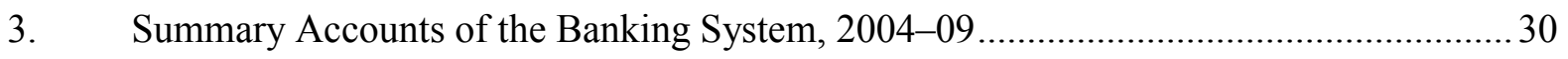

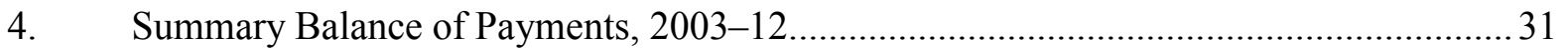

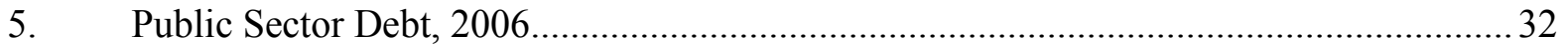

6. Indicators of Financial and External Vulnerability, 2001-06 .......................................... 33

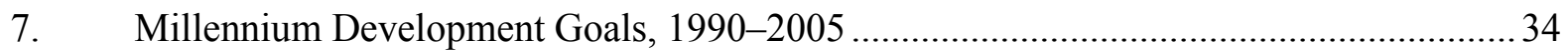

Annex

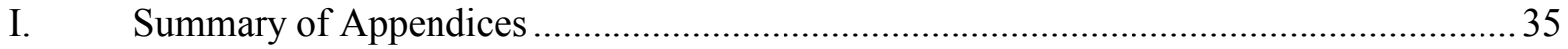

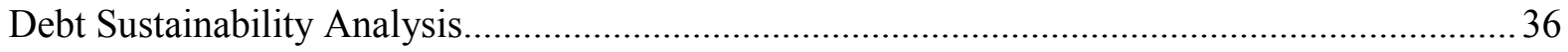




\section{CONTEXT FOR Discussions}

\section{A. Background}

1. In recent years, a series of exogenous shocks have buffeted Grenada, causing sharp fluctuations in output and putting pressure on the fiscal accounts (Figure 1). Hurricanes in 2004 and 2005 wreaked unprecedented damage (estimated at more than 200 percent of GDP), compounding the sharp dropoff in tourism after the September 11, 2001 attacks in the United States.

2. Grenada's public debt rose sharply in this period. Initially, the authorities tapped international capital markets, nearly doubling public debt ratios. Subsequently, the massive destruction caused by the hurricanes complicated the authorities' nascent efforts to tackle the large fiscal imbalances. They recognized that public debt was unsustainable and initiated a collaborative debt restructuring.

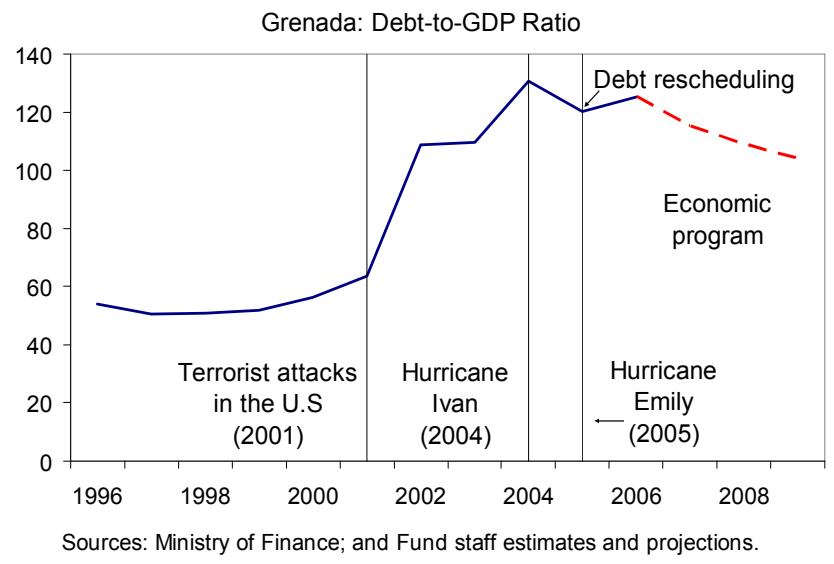

3. In 2006, the authorities launched a comprehensive medium-term economic reform program, developed in consultation with civil society groups. Its key objectives are sustained high economic growth, restoring fiscal and debt sustainability, reducing vulnerabilities, and alleviating poverty.

\section{The Fund supported the authorities' program with a PRGF arrangement} approved in April 2006, but the first review has not yet been completed. ${ }^{1}$ Large fiscal slippages in 2006 (which have continued into this year) resulted in missing the performance criterion on the central government primary balance by a substantial margin. The slow pace of structural reforms also contributed to the delay with the review. Lack of action in addressing the longstanding issue of an unregulated bank was another key factor. The situation with the bank has been complicated by the bank's lawsuit against the government and the Eastern Caribbean Central Bank (ECCB), with the validity of the bank's license in contention and the resulting lack of clarity over supervisory authority.

\footnotetext{
${ }^{1}$ Grenada-Request for Three-Year Arrangement Under the Poverty Reduction and Growth Facility (IMF Country Report No. 06/277).
} 
Figure 1. Grenada: Economic Developments (In percent of GDP)

Since the start of the new millennium, Grenada has been buffeted by external shocks...

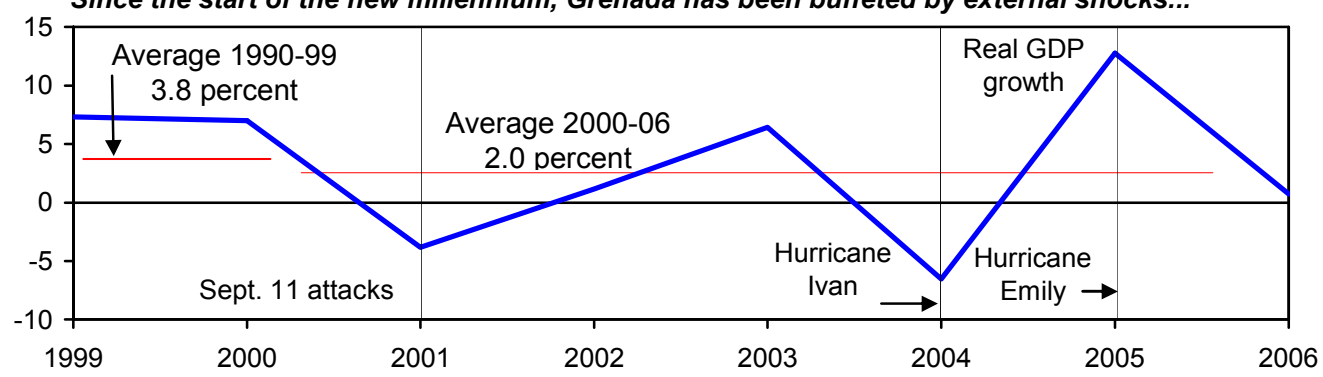

...putting pressure on government finances, which resulted in a debt restructuring...
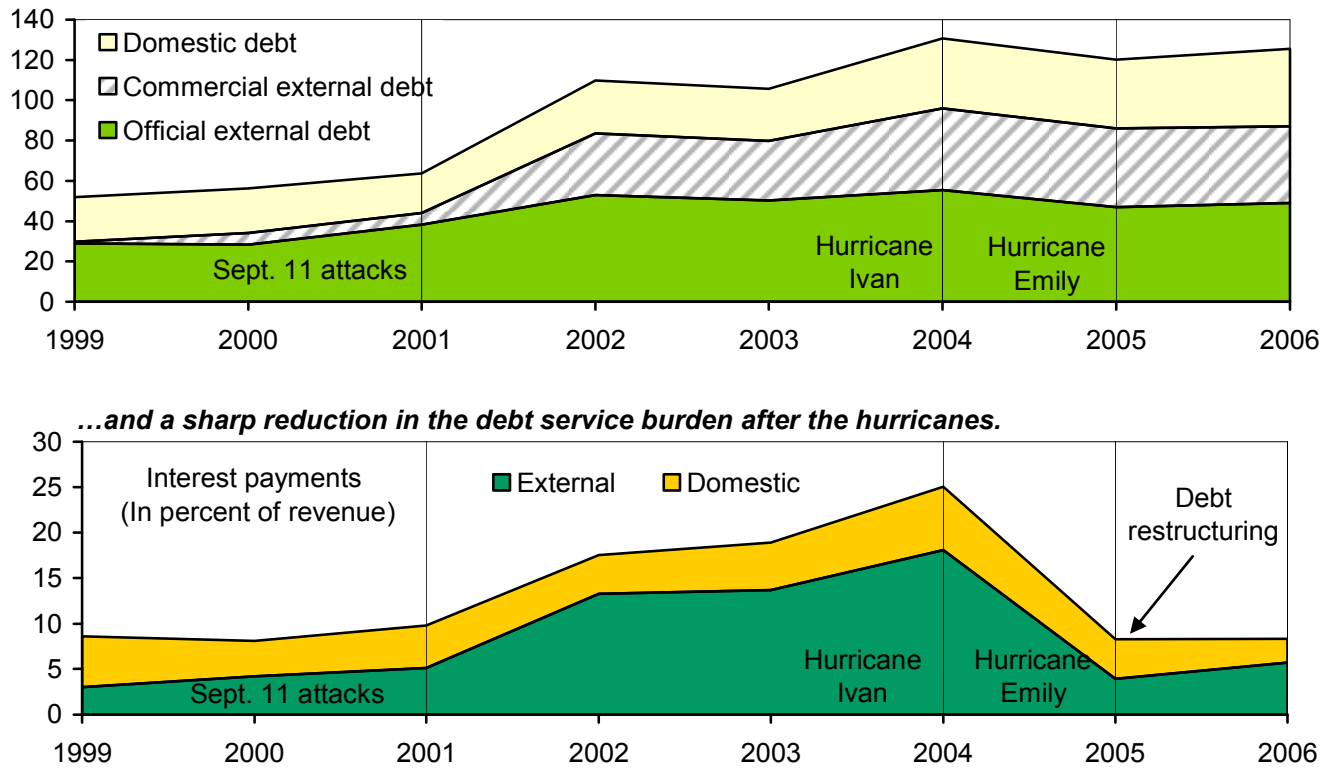

Grenada, nevertheless, remains in the ranks of the most indebted emerging markets.

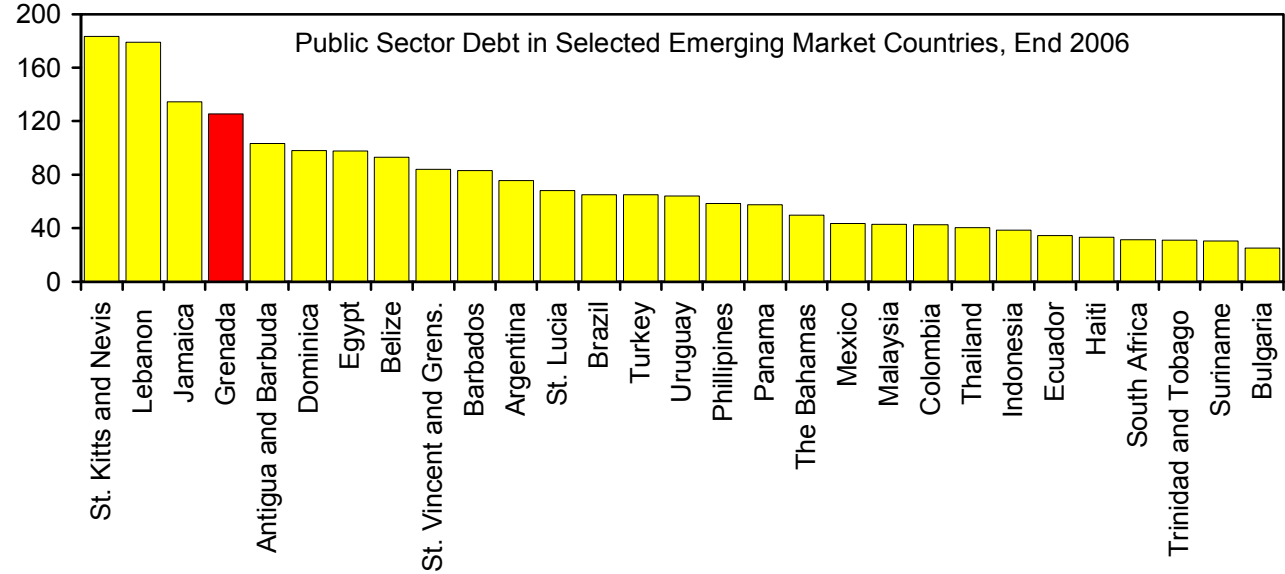

Sources: Grenada authorities; and Fund staff estimates. 
5. While Grenada has been very receptive to the Fund's policy advice, implementation has been challenging. The authorities have actively sought Fund and CARTAC technical assistance, particularly in the areas of tax policy, debt management, statistics, and the financial sector regulatory framework. However, limited capacity (e.g., staffing constraints, difficulties with intensive economic monitoring) and political constraints contributed to implementation difficulties. In hindsight, the government also viewed some aspects of the original PRGF program as being too ambitious.

\section{Social indicators are} somewhat weaker than in other ECCU countries. Grenada is currently undertaking a Country Poverty Assessment (CPA) - a key component of the Poverty Reduction Strategy Paper (PRSP) — to gain a clearer picture of developments on the social front since the hurricanes. The CPA's results should be available by end-

\section{B. Recent Developments and Outlook}

\section{The economy has largely recovered following Hurricanes Ivan and Emily:}

- Economic activity has rebounded strongly, with annual real GDP growth averaging 7 percent during 2005-06, driven by reconstruction, preparations for the Cricket World Cup (CWC), and revival of the tourism sector.

\section{- Inflationary pressures have dissipated.} After peaking at almost 6 percent at end-2005 following a large adjustment to domestic fuel prices, 12-month CPI inflation declined to 2.5 percent by May 2007. Notwithstanding this sharp decline in headline inflation, rising food prices have led the government to use moral suasion with importers of basic food items to reduce their margins.

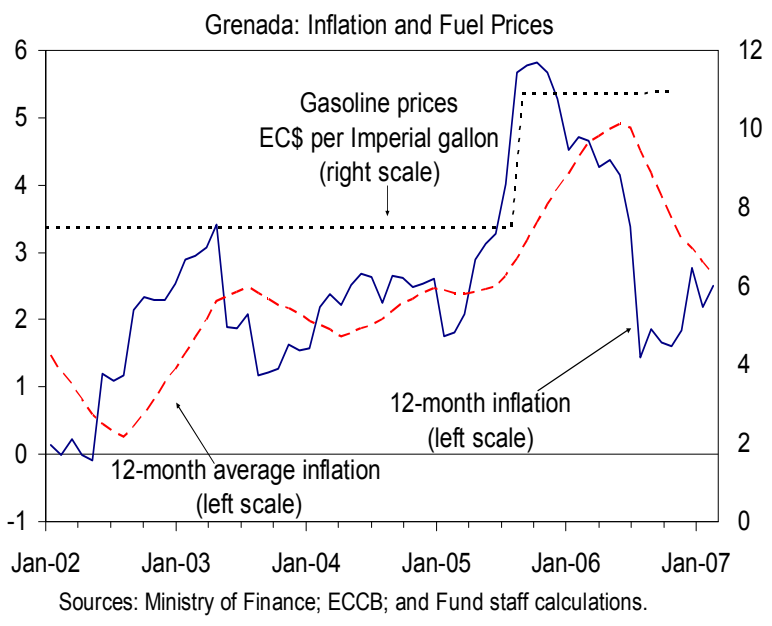


- External developments have been driven by post-hurricane effects. Following a spike in 2005 due to the post-hurricane construction boom, imports declined during 2006. Exports also fell, reflecting the depletion of nutmeg stocks and the long lead time required for nutmeg production to recover. The current account deficit in 2006 improved slightly, with rising tourism receipts nearly offsetting the decline in insurance payouts after 2005. The evolution of the current account in 2005-06 reflected the impact of the hurricanes, as indirect indicators suggest an improvement in competitiveness (Figure 2). Foreign direct investment financed about 40 percent of the current account deficit. During January-May 2007, stayover tourist arrivals grew nearly 10 percent over the previous year, toward pre-hurricane levels. In the first quarter of 2007, cocoa exports came back on line, while the value of other exports remained broadly constant. With imports picking up and a decline in income and transfers, the first quarter current account deficit widened slightly.

- Monetary developments have been favorable. Growth in credit to the private sector, which had declined sharply after Hurricane Ivan, picked up pace in 2006 and 2007. The leading contributors to the rise in credit were construction and tourism, while loans to agriculture fell.

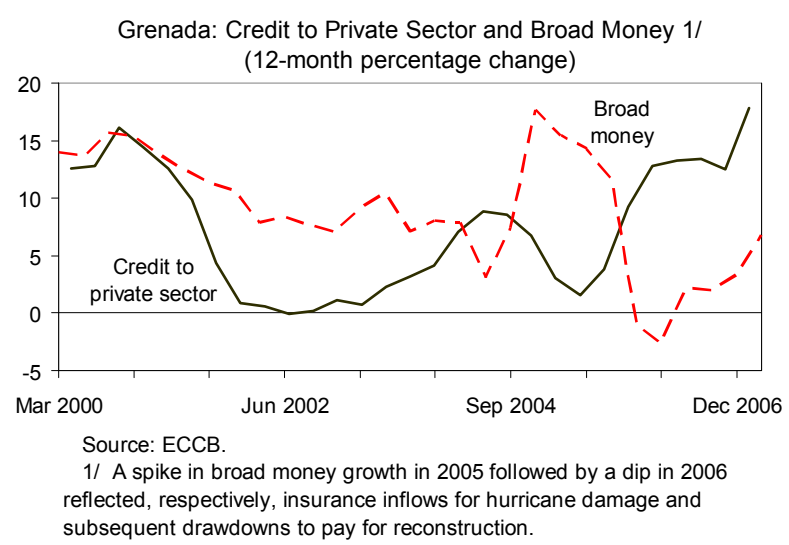

8. Fiscal performance deteriorated markedly in 2006 (Figure 3). Tax collection was lower than programmed during 2006, the result in part of negotiated revisions to the parameters for the National Reconstruction Levy (NRL) (with a rate of 3 percent rather than the planned 5 percent). At the same time, spending on goods and services was greater than projected, reflecting higher utility costs and transfers to households. Government investment reached 20 percent of GDP, about 5 percentage points higher than envisaged, on the back of higher-than-expected costs for reconstruction and preparations for the CWC. These expenditure overruns led to a primary deficit almost 7 percentage points of GDP higher than targeted (measured on a below-the-line basis). The resulting deficit was financed through the accumulation of domestic arrears (which they intend to clear, as soon as they have the resources), a drawdown of deposits, and an increase in public debt that raised the debt-toGDP ratio from 120 percent at end-2005 to 125 percent by end-2006. 
Figure 2. Grenada: Competitiveness Indicators

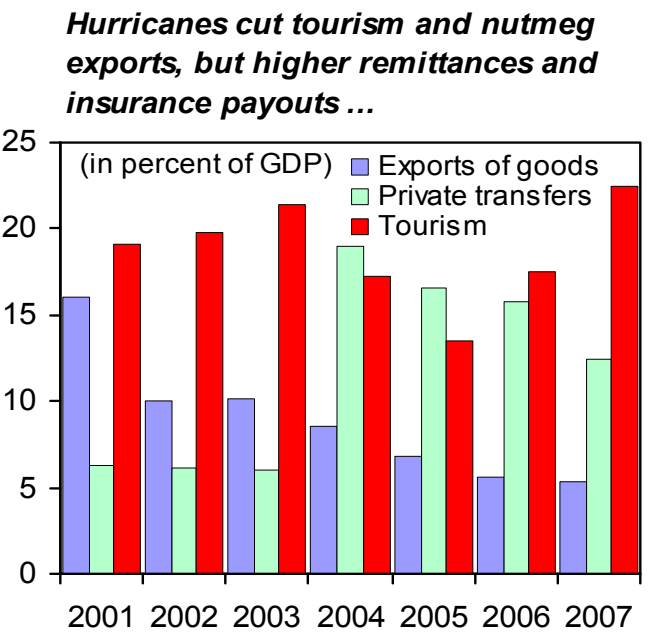

\section{Competitiveness is not an issue, as measured by the CPI-based REER..}
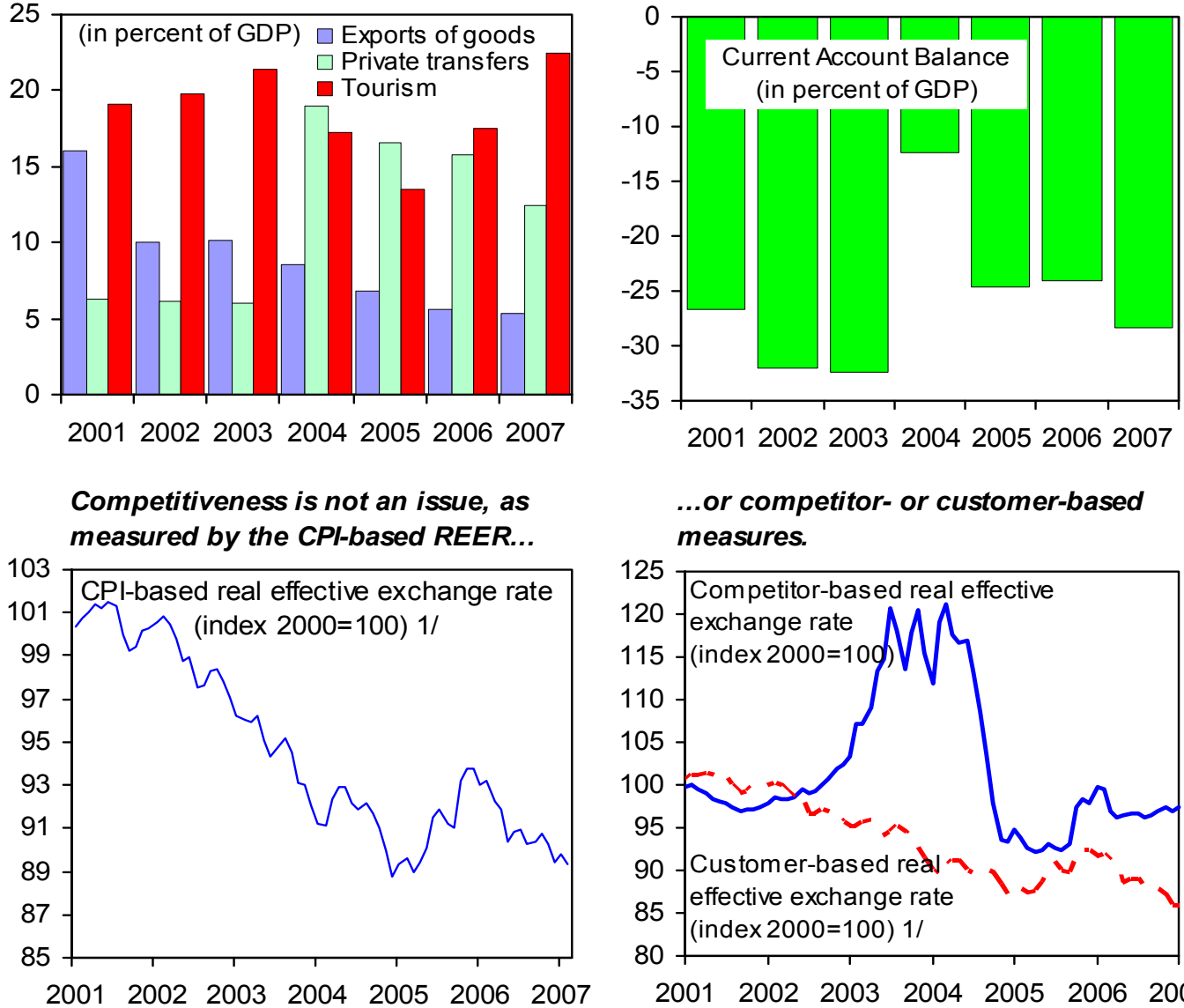

... kept the current account relatively unchanged.

2001200220032004200520062007

\section{...or competitor- or customer-based measures.}

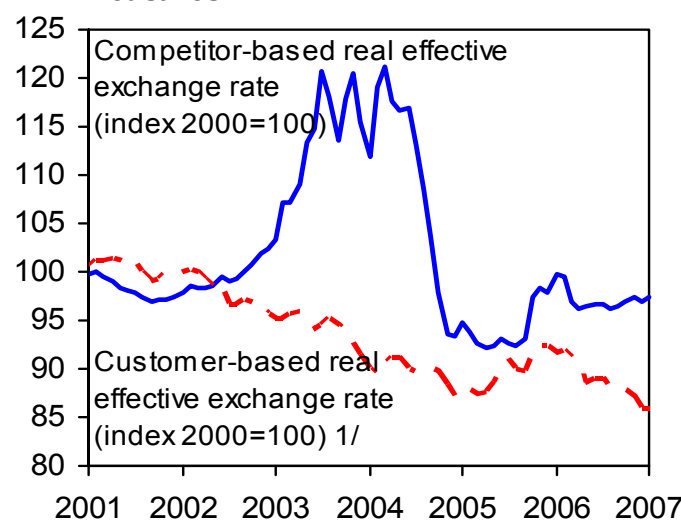

The decline in Grenada's tourism following the hurricanes has been partially reversed...
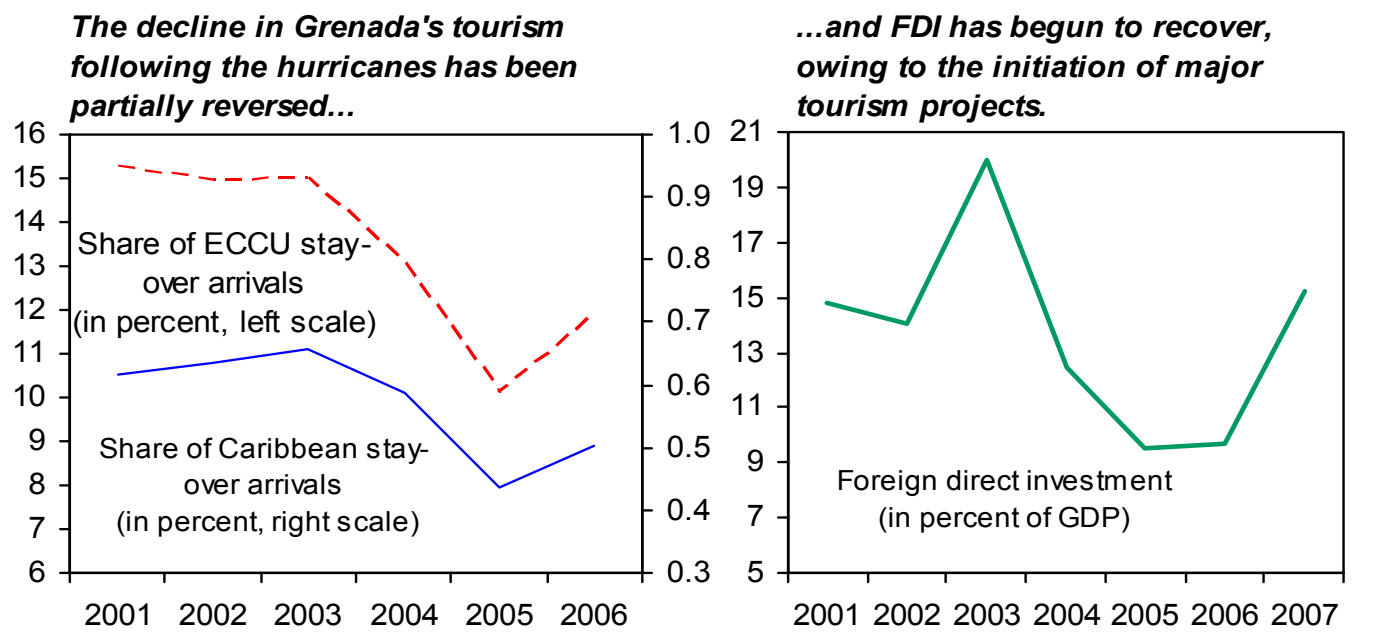

Sources: Grenada authorities; ECCB; Caribbean Tourist Organization; and Fund staff calculations. 1/ An increase (decrease) indicates an appreciation (depreciation). 
Figure 3. Grenada: Fiscal Sector Indicators

(In percent of GDP)

The 2006 fiscal outturn and 2007 budget deviated sharply from the PRGFsupported program...

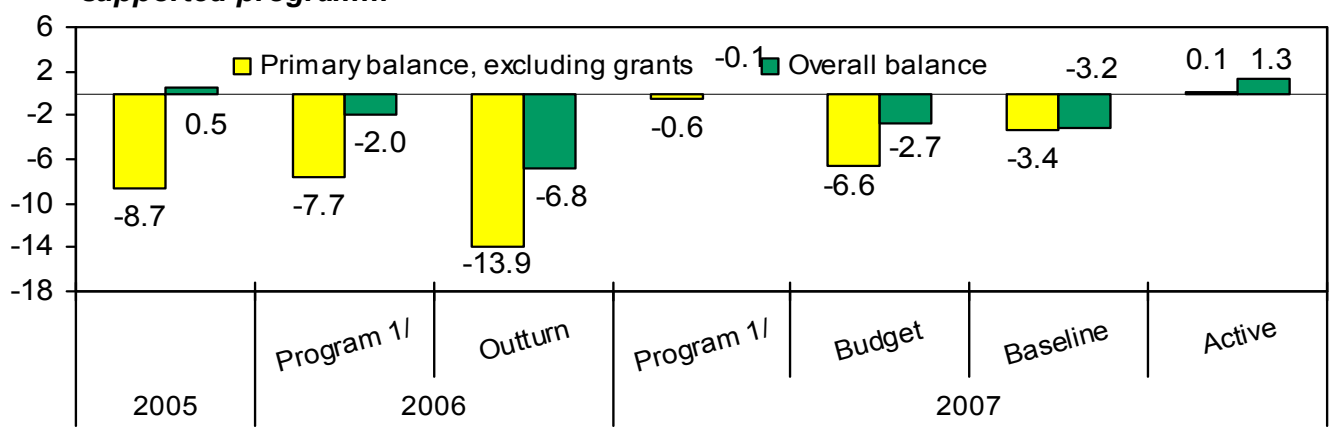

...due to large capital expenditure overruns...

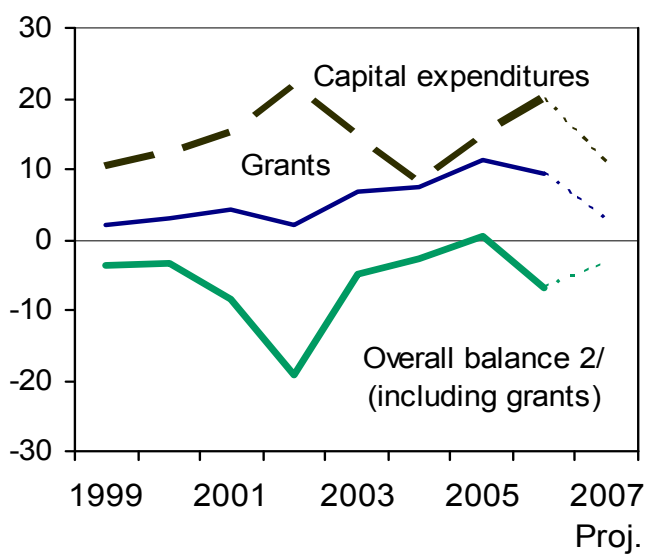

....and a delay in agreement on public service wages that kept the wage bill constant

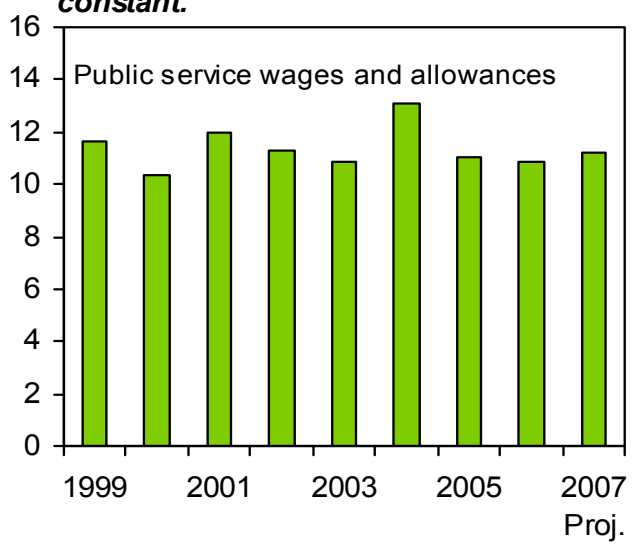

...and despite improved revenue performance after introduction of the National Reconstruction Levy...

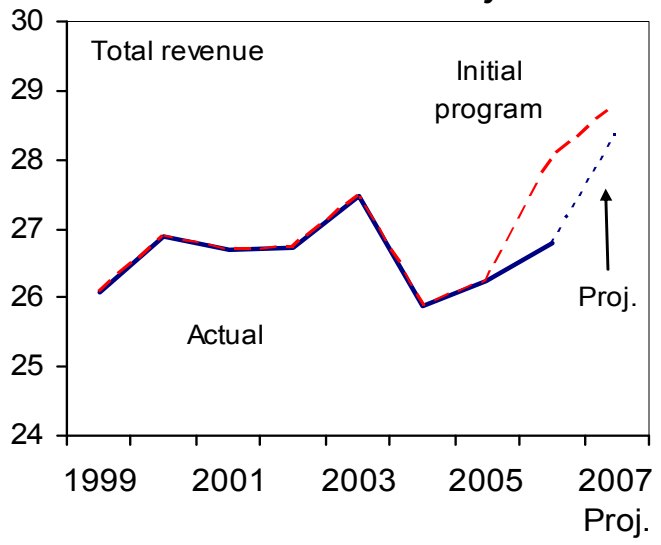

Grenada's wage bill, however, remains low by regional standards.

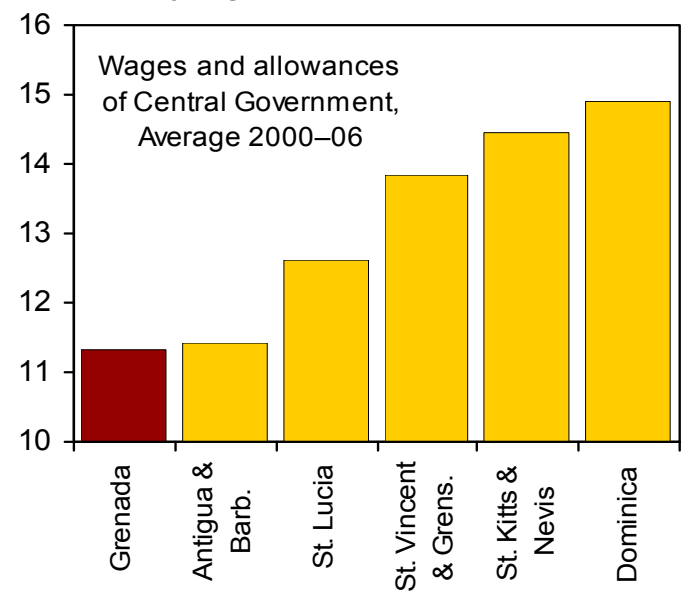

Sources: Grenada authorities; ECCU country authorities; and Fund staff estimates. $1 /$ Adjusted and reflecting revised GDP.

2/ Includes 11.4 percent of GDP paid in 2002 to extinguish lease arrangements. 
9. Data through the first half of $\mathbf{2 0 0 7}$ indicate that fiscal slippages have continued. Despite a substantial shortfall in grants relative to pledges, expenditures have not been kept in check, with transfers higher than projected and capital spending outpacing grant financing. ${ }^{2}$ The overall deficit during the first half of 2007 reached 2.2 percent of annual GDP, compared with the revised program target of 1 percent for the whole of the year. This deficit was financed primarily through overdrafts and the drawdown of deposits. In addition, the government accumulated arrears amounting to EC \$20.3 million on unrestructured domestic debt to the nonbank public due on June $30 .^{3}$

\section{Implementation of the authorities' structural reform program has been uneven:}

- with solid progress in the implementation of fiscal measures. The politicallydifficult NRL came into effect in early 2006. An automatic fuel pricing mechanism was adopted in October 2006 to protect revenues from oil price fluctuations. The collection of tax arrears is being strengthened. Publication of information on tax concessions has begun. Work towards the implementation of a VAT is proceeding, with the authorities aiming for introduction in early 2008.

- and important steps toward reducing vulnerabilities. Grenada recently established a single regulatory agency - Grenada Authority for the Regulation of Financial Institutions (GARFIN) — to strengthen supervision over the nonbank financial sector. To mitigate the risk of further natural disasters, Grenada signed up for the World Bank's Caribbean Catastrophe Risk Insurance Facility (CCRIF) and is taking steps toward giving the Building Code force of law.

- but with delays in advancing other structural reforms. Under their economic reform program, the authorities set out seven measures (structural benchmarks under the PRGF program); so far, only three have been met, two with delay. The biggest stumbling block was on tax concessions, as the authorities continued to grant

\begin{tabular}{|c|c|c|}
\hline & Target Date & Status \\
\hline Stop granting or extending tax holidays & Jan. 2006 & Not met \\
\hline $\begin{array}{l}\text { Agree on public service wage path for } \\
2006-08\end{array}$ & Apr. 2006 & Not met \\
\hline Initiate work to strengthen PSIP process & Jun. 2006 & $\begin{array}{l}\text { Met in July } \\
2006\end{array}$ \\
\hline $\begin{array}{l}\text { Publish information on new tax } \\
\text { concessions }\end{array}$ & Jun. 2006 & $\begin{array}{l}\text { Met in Sep. } \\
2006\end{array}$ \\
\hline Amend the Income Tax Act & Jun. 2006 & Not met \\
\hline Repeal tax incentives legislation & Jun. 2006 & Not met \\
\hline Initiate comprehensive customs reforms & Aug. 2006 & Met \\
\hline
\end{tabular}

\footnotetext{
${ }^{2}$ Grants were expected to finance almost half of 2007 capital expenditures, but have, in fact, only financed about one eighth.

${ }^{3}$ The authorities informed the bond holders that full payment would be made by the fourth quarter of 2007.
} 
tax holidays, based on their experience negotiating with several large investors. The benchmarks on legislative action regarding tax concessions will only be met by end2007, and in modified form. An agreement with trade unions on the public service wage path is yet to be reached, reflecting trade unions' skepticism about the accuracy of official inflation data. Resolving the issue of the unregulated bank remains outstanding (see -27). Other reforms - from public sector modernization to the onestop shop for investors - have been delayed, mainly reflecting capacity constraints.

11. The economic outlook is favorable. Boosted by the initiation of several major upscale tourism projects and the continued gradual recovery of agriculture, real GDP is projected to grow at 3 percent in 2007 and 4 percent thereafter. The investment projects are expected to generate significant spillover effects on the broader economy, including increased employment; linkages with the agricultural and other sectors; and substantial oneoff financial resources for the government in the form of land transfer taxes and proceeds from land sales. The effects are already being felt, with land prices having doubled in parts of Grenada over the past year.

\section{The political environment for reform remains challenging, as the government} has a one-vote majority in the Parliament. Although elections are not due until February 2009, there is speculation that the government might call an early election. The political cycle appears to be in full swing, complicating the prospects for fiscal adjustment and other structural reforms.

\section{Policy Discussions ${ }^{4}$}

Discussions centered on the key macroeconomic challenges facing Grenada: restoring fiscal and debt sustainability, safeguarding financial sector stability, managing vulnerabilities, and enhancing competitiveness to underpin growth.

\section{A. Restoring Fiscal and Debt Sustainability}

\section{The overarching objective of the government's reform program is to restore} fiscal and debt sustainability. The government's highly successful debt restructuring (now largely complete) has resulted in substantial debt service savings (Box 1). Furthermore, as

\footnotetext{
4 Staff visited St. George's on four occasions from September 2006 through April 2007, with the aim of completing the First Review Under the PRGF. The authorities then agreed to proceed with the 2007 Article IV discussions during July 11-17, 2007. The missions met with Prime Minister Mitchell, senior government officials, the opposition, trade unions, and representatives of the banking and business communities. The team included Nancy Wagner (Head), Pablo Druck, and Hunter Monroe (all WHD), with José Fajgenbaum (WHD), David Hofman (PDR), Thordur Olafsson (MCM), and Moni SenGupta (LEG) participating in some missions. Paul Jenkins (OED) joined the final discussions.
} 
noted above, a number of structural measures have been implemented to address the difficult fiscal situation. However, the government's plan to halve the debt-to-GDP ratio to 60 percent (the ECCB's established benchmark) by 2015 has been set back by the large fiscal slippages in 2006 and 2007. In light of emerging shortfalls in pledged grants, implementing the capital program for 2007 as budgeted would imply an overall fiscal deficit of $7 \frac{1}{2}$ percent of GDP.

\section{Box 1. Status of Debt Restructuring}

\section{Commercial debt}

Progress to date. A highly successful debt exchange was undertaken in November 2005. Overall participation reached 91 percent of eligible debt, or about US $\$ 237$ million (about 40 percent of total public debt). The restructuring involved a net-present-value reduction of 40-45 percent (using a 9 percent discount rate), for exit yields in the 9-10 percent range, and reduced debt servicing costs by 83 percent during 2005-08.

Outstanding issues. The authorities are making good faith efforts to find and engage the nonparticipating creditors. They have offered to one of them, holding about 5 percent of the eligible debt, a settlement on the same terms as the debt-exchange participants received. They are inviting remaining creditors to come forward.

\section{Debt to official bilateral creditors}

Progress to date. In May 2006, the Paris Club agreed to reduce debt service to Paris Club creditors by more than 90 percent for the duration of the PRGF arrangement. The Paris Club also agreed in principle to consider a further restructuring of Grenada's debt, if needed, at the end of the PRGF program. The authorities have signed bilateral agreements with Belgium, France, and the United States. Agreement is close with the United Kingdom, and have contacted the Russian Federation.

Outstanding issues. Under Paris Club rules, the rescheduling could be suspended if the first review under the PRGF is not completed. For non-Paris Club creditors, agreement is yet to be reached, including on the debt (and arrears) owed to Taiwan Province of China, Grenada's largest bilateral creditor. In March 2006, the Ex-Im Bank of Taiwan Province of China sued the Grenadian Government in New York, and the authorities are seeking an amicable resolution.

14. The current debt sustainability analysis (DSA) indicates that Grenada is at high risk of debt distress. ${ }^{5}$ Even a concerted effort to reduce debt would still leave the country highly vulnerable to another external shock. Moreover, Grenada's debt sustainability outlook

\footnotetext{
${ }^{5}$ See the supplement to this report, Debt Sustainability Analysis.
} 
has deteriorated since the last DSA. ${ }^{6}$ While some of this deterioration is due to a change in underlying assumptions, ${ }^{7}$ most is caused by the fiscal slippages of the last $12-18$ months.

\section{The authorities recognized that corrective action was needed to address the}

slippages. They explained that the expenditure overruns resulted from greater-thananticipated costs of reconstruction, combined with pressing development needs and CWC preparations. As a corrective action, the government agreed to work closely with line ministries to reprioritize capital projects, with the aim of substantially lowering capital expenditure this year. They have also been trying to reach agreement with trade unions on a public sector wage package which, although allowing for a real increase in wages, would still reduce the wage bill as a percent of GDP over time. The authorities also expect substantial divestment proceeds this year from the sales of land for prospective tourism projects and of equity shares in some companies; they plan to use half of such proceeds to pay down expensive debt and the remainder to finance their capital program. These measures taken together should be sufficient to contain the overall deficit to about $3 \frac{1 / 4}{4}$ percent of GDP this year and the primary deficit (including grants) to about 1 percent of GDP.

\section{The mission stressed that Grenada's high public debt leaves little room for} maneuver, reducing the country's flexibility to respond to any future shocks. If another strong hurricane were to strike, this could substantially delay the achievement of fiscal and debt sustainability. Moreover, the recent reliance on unsustainable financing sources raises the risk of disorderly adjustment and could further undermine the government's financial reputation. ${ }^{8}$ The mission, therefore, stressed the need to adopt the stronger policy framework proposed in the active scenario discussed below. Such a stance would help unlock disbursements of grants and concessional financing from the donor and creditor community, including the European Union (EU)and the Caribbean Development Bank (CDB). ${ }^{9}$

\footnotetext{
${ }^{6}$ See IMF Country Report No. 06/277, Annex I, Medium-Term Outlook and Debt Sustainability.

${ }^{7}$ The previous DSA included only half of guaranteed debt and assumed a discount rate of 9 percent. The current DSA includes all guaranteed debt and assumes a discount rate of 5 percent, consistent with the Debt Sustainability Framework for Low-Income Countries.

${ }^{8}$ Standard and Poor's downgraded Grenada's credit rating from B- to CCC + in April 2007, citing rising fiscal pressures and lack of payments discipline, including arrears (since cleared) to domestic commercial banks. In August 2007, the rating agency reversed the downgrade, owing to "measures taken in June 2007 to streamline the government's debt-payment mechanism," noting that this "significantly reduced the risk of new intermittent arrears." These measures included a standing order with a bank to service government debt held by other banks from the government's deposit account.

9 For example, disbursement of the first tranche of the EU's budget support (planned for 2007) is dependent upon "overall satisfactory assessment of Grenada's macroeconomic framework, as verified by evidence provided in an IMF assessment."
} 
17. Under the active scenario, the authorities could reach their debt-to-GDP ratio of 60 percent by 2017, three years ahead of the ECCB's revised regional target date. This scenario entails a small overall fiscal surplus and a primary surplus (including grants) of about 3 percent of GDP (Tables $2 \mathrm{c}$ and $2 \mathrm{~d}$ ) to be sustained over the next decade. This would require that capital expenditure in 2007 be limited to just under 9 percent of GDP, consistent

Grenada: Evolution of Debt-to-GDP Ratio (In percent of GDP)

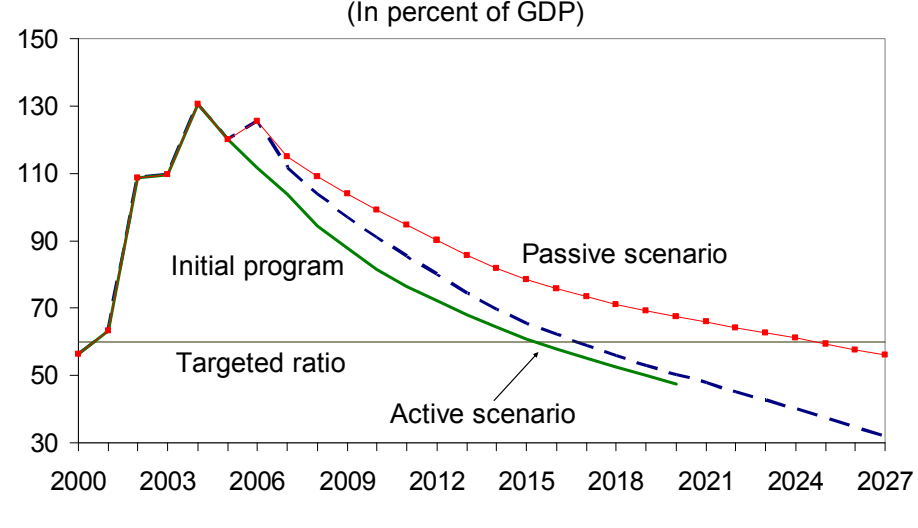

Sources: Ministry of Finance; and Fund staff estimates and projections. with the fact that reconstruction is largely completed, and to 8 percent thereafter, in line with the historical average before the recent shocks. It would also require implementing some additional revenue-enhancing measures over the medium term (e.g., an inflation adjustment to the fuel surcharge); and keeping real wages and spending on transfers, goods, and services constant over the medium term. The scenario assumes that all divestment proceeds would be used to clear arrears and pay down expensive debt, rather than to finance additional budgetary expenditures. This would prevent the erosion of the government's net asset position, as the reduction of its assets would be fully offset by the reduction in liabilities. In contrast, with the baseline scenario using current fiscal plans (Tables $2 a, 2 b$ and Box 1 in the supplemental DSA), the targeted debt ratio of 60 percent is only reached by 2025 .

Grenada: Fiscal Developments, 2005-07

(In millions of Eastern Caribbean dollars)

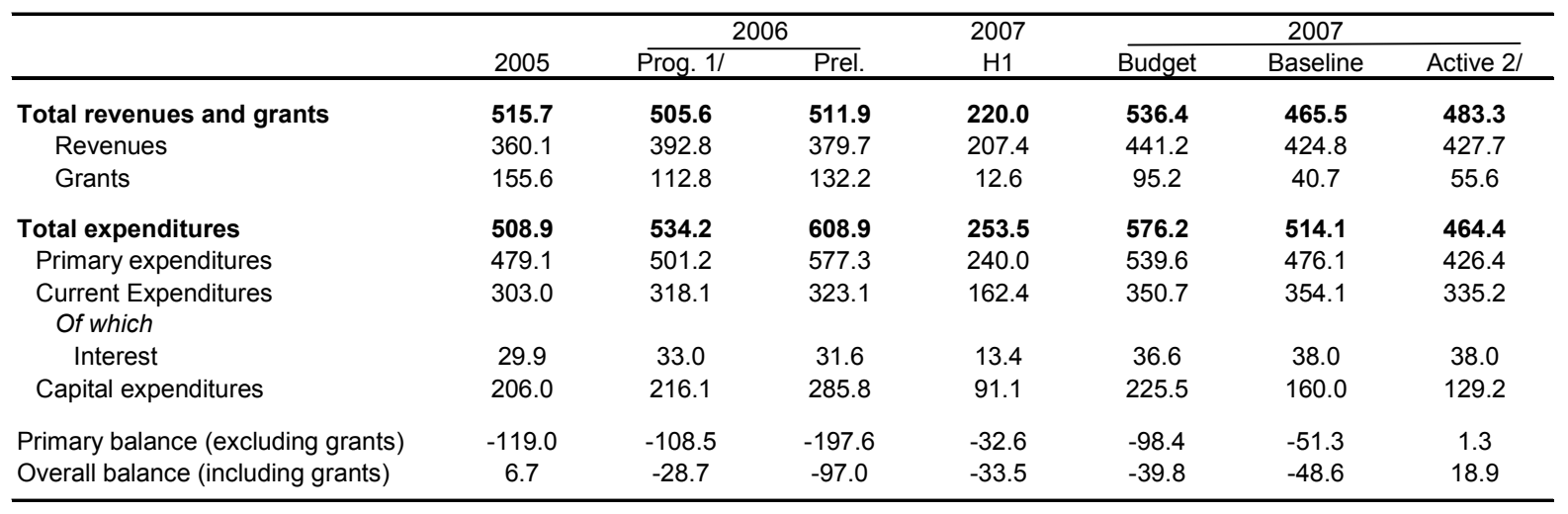

Sources: Ministry of Finance; and Fund staff estimates and projections.

1/ Based on the PRGF-supported program, adjusted and reflecting revised GDP

2/ The active scenario assumes that the First Review Under the PRGF can be completed by year-end.

18. In view of Grenada's high debt levels, the authorities have chosen a conservative approach to managing the concessional financing associated with the PetroCaribe Agreement. They intend to use this financing judiciously, with a view to improve the debt service profile, by investing the net present value of the future debt obligations in an 
earmarked account and using only the remainder as financing for budgeted social programs (thus replacing more expensive forms of budget financing). The mission supported this approach, but advised that all associated expenditures be transparently recorded on budget and that safeguards be put in place to ensure that the funds in the earmarked investment account are used as planned. It also stressed the importance of seeking further technical assistance to build up debt management capacity. The authorities concurred with staff's recommendations.

\section{The mission underscored the importance of strengthening public finance} management if the government is to achieve its fiscal goals. In particular, it encouraged the government to enhance its capacity through intensive training in Public Sector Investment Program (PSIP) techniques. ${ }^{10}$ Staff welcomed the steps toward strengthening fiscal oversight by adopting new guidelines for extra-budgetary spending in June 2007, which require that all requests for such spending be directed to the ministry of finance before submission to Cabinet. In the context of adopting a ten-year National Strategic Plan, the authorities expressed interest in moving toward multiyear budgeting, which the mission strongly supported.

\section{The authorities have revisited plans to stop granting tax holidays in light of} recent negotiations with top-tier investors. This experience indicated that, notwithstanding the high cost of concessions to the budget, a unilateral elimination would place Grenada at a strong disadvantage in the highly competitive regional horse race for major investments. While regretting the continued reliance on tax holidays, staff agreed that a preferred approach would be a broad-based regional agreement to abolish this distortionary practice. In the absence of such an agreement, staff stressed that, at a minimum, any further granting of tax holidays should be done in a transparent,

Tax Competition in the Caribbean

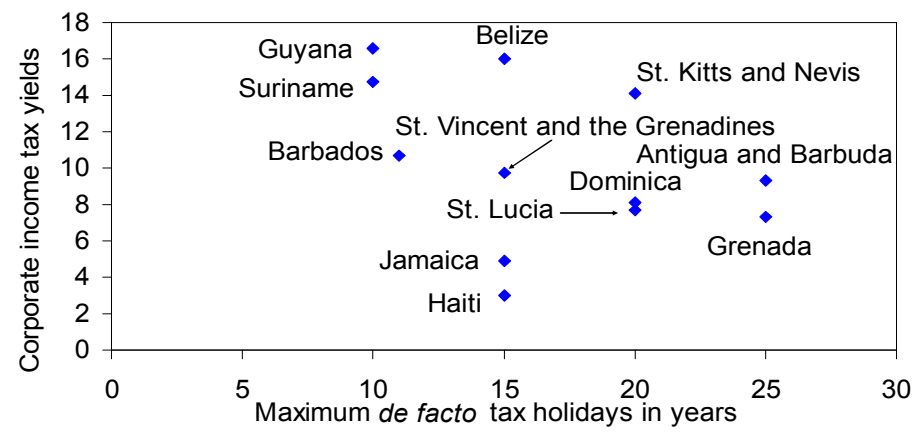

Source: Fund staff calculations, based on 2006 data for the ECCU, Suriname, and Haiti and 2003 data for others. The tax yield is revenue as a percent of GDP divided by the tax rate. nondiscretionary manner and only to qualifying projects above a sufficiently high threshold so as to minimize the adverse impact on the fiscal accounts.

\section{The authorities plan to reassess the value of real estate for property tax}

purposes. A substantial increase in property taxes is expected, given that property values have not been adjusted since 1994. The authorities anticipate completion within two years.

\footnotetext{
${ }^{10}$ In early 2007, the authorities received preliminary training from the CDB in such techniques.
} 
The mission agreed with the authorities' approach to increase property taxes in a stepwise manner to smooth the transition to higher taxes.

22. The mission commended the government for stepping up efforts to improve tax collection and reform tax administration. Particularly important has been the creation in early 2007 of a new unit in Inland Revenue to collect tax arrears, with the aim of collecting about EC \$18 million annually over the next few years. Reforms will focus first on the implementation of the VAT, but will be broader reaching as well, particularly for Customs, including the simplification of customs clearance and strengthening of audit capacity, risk management, anti-smuggling, and fraud detection. Staff suggested that the authorities set a firm timetable for carrying out the planned reforms.

23. The authorities viewed the future VAT as the cornerstone of a more efficient and effective tax system. The VAT (together with excise taxes) will replace the general consumption tax and several nuisance taxes, with the chosen parameters based on revenueneutrality (in practice, however, the strengthened tax administration being put in place is expected to imply some revenue enhancement). Although the authorities launched the White Paper in January 2007, the VAT's introduction is likely to be delayed into the first half of 2008 (from October 1, 2007). The mission encouraged the government to address the business community's uncertainty over the date of implementation and to avoid further delays by pressing ahead with key actions, including recruiting and training of staff, passing the VAT and excise legislation, and adopting transitional procedures for bonded warehouses.

\section{The authorities remain committed to reducing poverty and improving social}

indicators. They agreed that expenditure priorities should be in line with the social development agenda described in the country's PRS, now under preparation. The government has worked closely with donors to secure the resources necessary to build new housing for those displaced after the hurricanes and to rebuild the health and education infrastructure. Youth training and development are core components of the efforts to reduce unemployment. The government also plans to maintain the initiatives put in place in 2006 to cushion the impact of fuel price increases on vulnerable groups.

\section{B. Safeguarding Financial Sector Stability}

25. Safeguarding the stability of the domestic financial sector has been a top priority of the government. The authorities recognized that strong financial sector supervision remains key to mitigating risks. Under GARFIN, the authorities have begun to step up supervision of the broader financial sector and are continuing to benefit from CARTAC's assistance to strengthen the new agency's capacity. 
26. There was broad agreement that Grenada's banking sector had weathered well the impact of the hurricanes. Indeed, Grenada's financial indicators were among the region's strongest prior to Hurricane Ivan. In the aftermath, insurance payouts and external assistance helped preserve a high level of liquidity. Moreover, the debt restructuring was designed to minimize the impact on the banking system. Although the share of nonperforming loans increased following Hurricane Ivan, this has been steadily declining and is now below pre-hurricane levels.

Grenada: Selected Financial Sector Indicators, 2001-06 1/

\begin{tabular}{|c|c|c|c|c|c|c|}
\hline & 2001 & 2002 & 2003 & 2004 & 2005 & $\begin{array}{r}\text { Est. } \\
2006 \\
\end{array}$ \\
\hline Capital adequacy ratio & 14.1 & 15.6 & 17.7 & 14.9 & 15.3 & 17.5 \\
\hline Nonperforming loans/total loans & 5.9 & 5.8 & 4.5 & 6.0 & 5.5 & 3.7 \\
\hline Locally incorporated banks & 9.3 & 9.0 & 7.2 & 7.1 & 6.8 & 4.7 \\
\hline Foreign banks & 1.4 & 1.3 & 0.6 & 4.4 & 3.5 & 2.4 \\
\hline Loan-loss provisions/NPLs & 43.6 & 45.6 & 61.7 & 81.9 & 79.4 & 67.4 \\
\hline Locally incorporated banks & 40.6 & 39.3 & 49.5 & 63.0 & 60.7 & 51 \\
\hline Foreign banks & 71.1 & 106.9 & 301.3 & 127.8 & 134.6 & 114.6 \\
\hline Gross government claims/total assets & 14.3 & 15.6 & 13.9 & 11.3 & 11.2 & 11.6 \\
\hline Foreign currency deposits/total deposits & 7.3 & 6.9 & 7.3 & 5.6 & 7.8 & 5.8 \\
\hline (Pre-tax) return on average assets & 2.4 & 2.3 & 2.8 & 0.5 & 0.7 & 2.5 \\
\hline
\end{tabular}

Source: ECCB.

1/ Excluding the unregulated bank.

\section{The mission urged the authorities to address the longstanding issue of an}

unregulated, fast-growing bank. Owing to a dispute over the validity of the bank's license, the ECCB does not supervise the bank and has kept it out of the formal clearing and payments system. The mission strongly encouraged the authorities to find an approach, consistent with Grenada's legal framework, to supervise the bank and to conduct an independent assessment to determine the bank's financial condition. The authorities believed that the bank's operations posed risks to the rest of the financial sector, although they are contained because other banks have tried to limit their linkages with this bank. The authorities recognized the importance of having all financial institutions properly supervised and are exploring options in this regard. Progress in this area would also be a key step toward completing the First Review Under the PRGF program. 
28. The commencement of GARFIN's operations in March 2007 has provided an ideal opportunity to address some remaining gaps in the regulatory and supervisory framework. The mission welcomed the authorities' plans to make several crucial amendments to the GARFIN Act to make it more effective. In this context, foreign exchange trading services and micro-financing will be defined as money services business to bring such activities under the supervision of GARFIN. ${ }^{11}$ With the new supervisory agency still in its early stages of operation, the authorities recognized that capacity-building was crucial for GARFIN to be able to fully carry out its responsibilities. Foreign exchange trading entities can also pose a significant risk of money laundering/terrorism financing (ML/FT), especially if they engage in funds-transfer services.

29. The authorities are aiming to enact a new Insurance Act by December 2007. In conjunction with GARFIN, the Act is expected to strengthen insurance supervision, improve contract certainty, and better protect policyholders. The mission expressed concern about the growing deposit-taking activities of insurance companies. Some of these companies are offering fixed-term deposits with annual interest rates up to 9 percent per year, far in excess of that offered by commercial banks, with the funds invested abroad. This activity has been undermining the client base for the domestic commercial banking system, and their much higher interest rates could indicate riskier investment activities on the part of the insurance companies (of which depositors may not be fully aware). In addition, the growth in deposittaking increases the potential risk of ML/FT activity in insurance companies to a level not dissimilar to that of banks and other deposit-taking entities. The mission welcomed GARFIN's plans to conduct a thorough investigation of insurance companies' activities and to determine, in coordination with the ECCB, whether banking licenses should be required.

\section{Managing Vulnerabilities}

30. Grenada remains highly vulnerable to exogenous shocks. Grenada's greatest vulnerability stems from the possibility of another natural disaster. In the aftermath of the hurricanes, some insurance companies have now expanded the "hurricane belt" to include Grenada. The economy is also now more dependent on tourism than it was at the time of the September 11 attacks as a result of the hurricanes' destruction of nutmeg production capacity. Grenada's highly-open economy is also vulnerable to terms-of-trade shocks, including movements in world fuel prices.

\footnotetext{
${ }^{11}$ A recently-formed foreign exchange trading service has been claiming a risk-return profile more akin to a pyramid scheme than a valid investment. Banks report that clients have even requested loans to invest with this company. The mission supported GARFIN's plans to obtain regulatory powers over this new type of financial company, and to act promptly after a full investigation.
} 
31. The mission commended the authorities' actions to mitigate the financial risks of natural disasters. Grenada has secured donor financing to pay its premium for the first three years for the World Bank's CCRIF. As this facility is only intended to provide

Worldwide Incidence of Natural Disasters, 1970-2005 1/

\begin{tabular}{|c|c|c|c|c|c|}
\hline & \multicolumn{5}{|c|}{ All Recorded Disasters } \\
\hline & \multirow{2}{*}{$\begin{array}{l}\text { Number } \\
\text { of Events }\end{array}$} & \multicolumn{2}{|c|}{$\begin{array}{l}\text { Number of Events } \\
\text { Divided by } \\
\text { Land Area }\end{array}$} & \multicolumn{2}{|c|}{$\begin{array}{c}\text { Number of Events } \\
\text { Divided by } \\
\text { Population }\end{array}$} \\
\hline & & Index & Rank & Index & Rank \\
\hline All countries & 7,963 & 100 & 93 & 100 & 93 \\
\hline Advanced economies & 1,601 & 10 & 103 & 37 & 113 \\
\hline Caribbean & 272 & 631 & 23 & 400 & 29 \\
\hline ECCU & 50 & 784 & 7 & 786 & 7 \\
\hline Antigua and Barbuda & 7 & 679 & 7 & 717 & 6 \\
\hline Dominica & 9 & 512 & 12 & 1,037 & 3 \\
\hline Grenada & 6 & 753 & 5 & 467 & 11 \\
\hline St. Kitts and Nevis & 7 & 829 & 4 & 1,210 & 2 \\
\hline St. Lucia & 9 & 619 & 10 & 451 & 12 \\
\hline St. Vincent and the Grenadines & 12 & 1,312 & 2 & 836 & 5 \\
\hline Other Caribbean & 222 & 540 & 34 & 168 & 43 \\
\hline Other & 6,090 & 55 & 98 & 77 & 96 \\
\hline
\end{tabular}

Sources: EM-DAT, WHO, for data on natural disasters; World Bank, World Development Indicators for data on land area and population.

1/ The sample contains 184 countries. Simple unweighted averages are used for country groupings. Rankings are in descending order, with " 1 " indicating the most exposed to natural disaster.

short-term liquidity support to the budget and not full insurance coverage, the mission welcomed the government's steps toward giving the Building Code force of law to prevent a repeat of the damage caused by the recent hurricanes.

32. Diversifying the economic base and increasing regional ties are other important means to reduce Grenada's vulnerability. The government has recently begun to implement a newly-developed National Export Strategy with the aim of economic diversification (e.g., moving toward higher value-added in the agricultural sector; marketing local arts and crafts; broadening the basis for tourism beyond "sun, sand, and sea"). The mission also encouraged the authorities to work toward continued external trade liberalization within CARICOM. OECS members (including Grenada) approved a draft treaty in May 2007 to establish an OECS Economic Union.

\section{In view of Grenada's high susceptibility to shocks, the mission stressed that a} core element for mitigating risks is to prepare a detailed risk management plan. It encouraged the government to develop such a plan, taking into consideration various scenarios, including those related to natural disasters, financial sector instability, and trade shocks. In addition, the mission recommended that the government create a contingency fund of at least 1 percent of GDP, to be held in a deposit account with the ECCB as a cushion to address any urgent, unanticipated liquidity needs. ${ }^{12}$

\section{A key vulnerability stems from large financing needs for the foreseeable future.} Owing to concerns about the government's repayment capacity, some local market

\footnotetext{
${ }^{12}$ This contingency fund is incorporated into the mission's recommended active policy scenario, but not the baseline scenario.
} 
participants noted that they would not lend to the government at this point, even to rollover debt. Rollover risk could be substantial for domestic debt, as outstanding treasury bills alone amount to 5 percent of GDP. ${ }^{13}$ The mission, therefore, stressed the importance of rebuilding the government's financial reputation through strong fiscal adjustment. The mission also highlighted the medium-term balance of payments vulnerabilities in the context of the high public debt burden. In particular, given the expected decline in grants, the sizable current account deficit (projected at 25 percent of GDP in 2007) implies that Grenada will become increasingly dependent on large FDI inflows. Should these flows fail to materialize, growth could suffer. This makes it all the more important that Grenada enhance its competitiveness and ensure its reputation is not impaired by fiscal or financial difficulties. ${ }^{14}$

\section{Enhancing Competitiveness}

\section{In the highly competitive global environment, a key factor determining}

Grenada's growth prospects is its international competitiveness. Discussions focused on the wide range of determinants of competitiveness, from relative pricing considerations (as indicated by the real effective exchange rate (REER), for example)) to the broader climate for investment.

\section{Exchange rate indicators} suggest that external competitiveness is currently not an issue. ${ }^{15}$ Higher world fuel prices account for the bulk of the adverse movements in Grenada's terms of trade. Movements in the real effective exchange rate (REER), including customer- or competitor-based measures, have been favorable (Figure 2), and Grenada has increased its share of ECCU stayover visitors. Grenada's

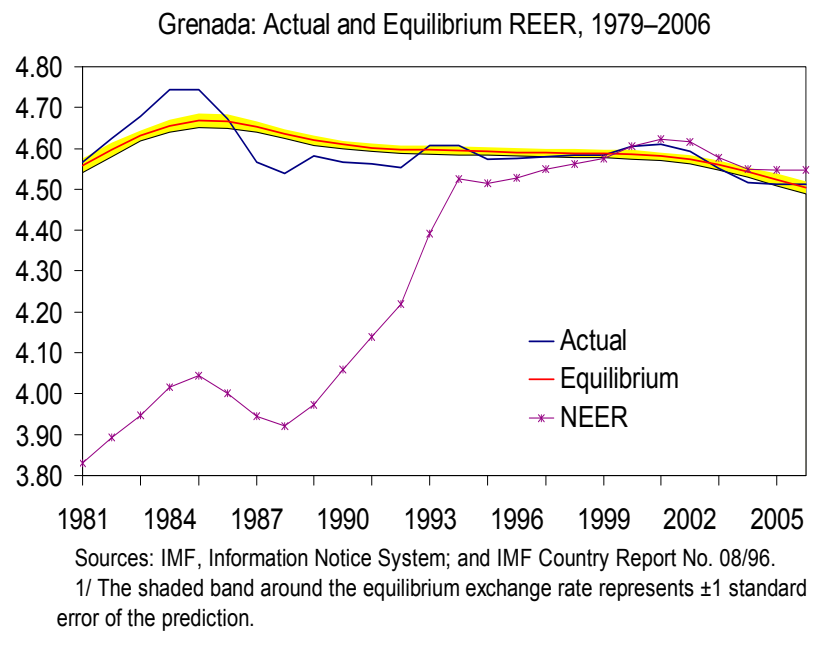

\footnotetext{
${ }^{13}$ The rescheduling of external debt has minimized the short-term rollover risk.

${ }^{14}$ While the ongoing repricing of credit is likely to make it more expensive for ECCU governments to borrow on commercial terms, there has been only a weak link between emerging market spreads and spreads observed on regional capital markets. See "Financial Integration in the Caribbean," forthcoming Executive Board paper.

${ }^{15}$ Grenada is a member of the ECCB, which manages monetary policy and the exchange system for its eight members. The common currency, the Eastern Caribbean dollar, has been pegged to the U.S. dollar at the rate of EC\$2.70 per U.S. dollar since July 1976.
} 
real exchange rate does not appear to be misaligned; staff analysis finds no statistically significant deviation of the REER from its estimated equilibrium level. ${ }^{16}$ The mission underscored, however, that fiscal consolidation will be important to support competitiveness and the sustainability of the currency board arrangement.

\section{Improving Grenada's business environment is also essential to sustain} competitiveness over the longer term. According to the World Bank's 2007 “Doing Business Indicators" report, Grenada ranks 73 out of 175 countries and does poorly amongst Caribbean competitors (Figure 4). Moreover, on several indicators - enforcing contracts (143), registering property (145), and closing a business (151) — Grenada scores in the bottom quintile.

\section{The authorities are determined to push ahead with reforms to enhance the} investment climate. Many of the planned reforms have suffered delays; for example, efforts to create a one-stop shop for investors ran into legal and technical problems, and resource constraints hampered plans to facilitate land transactions through upgrading the land registry. The newly-created ministry of economic development and planning - responsible for overseeing many of the agencies involved with investment planning and approval-may facilitate implementation of the reform agenda. The authorities have taken the World Bank ratings very seriously and have already developed a detailed action plan, in consultation with the business community, to address these weaknesses.

\section{STAFF APPRAISAL}

\section{The economy's rebound since the devastation of the hurricanes has been} remarkable. This is a testament to the Grenadian people's resilience, the donor and creditor communities' support and, not least, the government's impressive efforts to revive the economy, including the launching of a medium-term economic reform program in the aftermath of the hurricanes.

40. The government's reform program rightly focuses on the key economic challenges facing Grenada-fiscal and debt sustainability, durable high growth, poverty alleviation, and vulnerabilities. The government has made progress in addressing each of these areas: introducing politically-difficult but critical fiscal measures; working closely with creditors to restructure the debt; mobilizing donor support to finance reconstruction in 2005-06; initiating a wide range of structural reforms, with a unifying theme of enhancing the investment environment and reducing vulnerabilities; securing

\footnotetext{
${ }^{16}$ This assessment is based upon a time series model linking the REER to measures of Grenada's fundamentals. See Chapter I, "Assessing Exchange Rate Competitiveness in the Eastern Caribbean Currency Union," IMF Country Report No. 08/96.
} 
Figure 4. Grenada: Doing Business Indicators, 2006 1/

Grenada is ranked 73 out of 175 economies worldwide in the overall cost of doing business, and 5 out of 6 in the ECCU. But it can improve the business environment by...

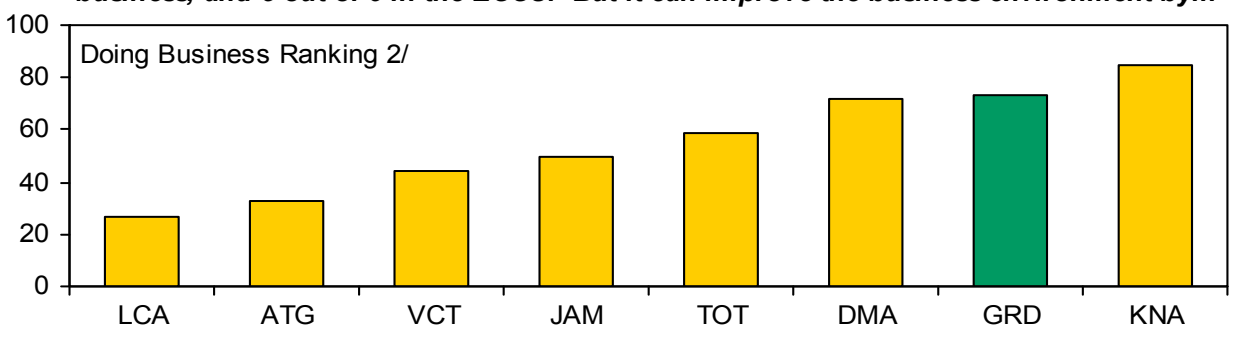

...removing obstacles to starting a business..

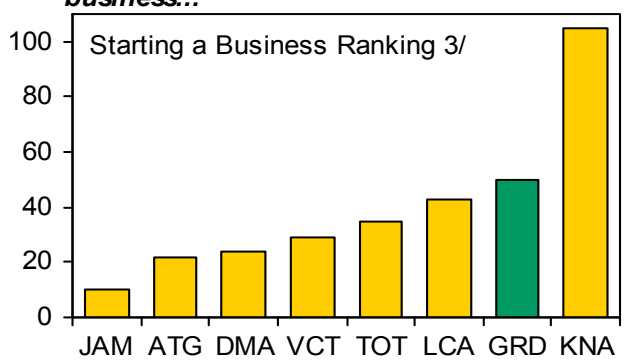

...improving contract enforcement...

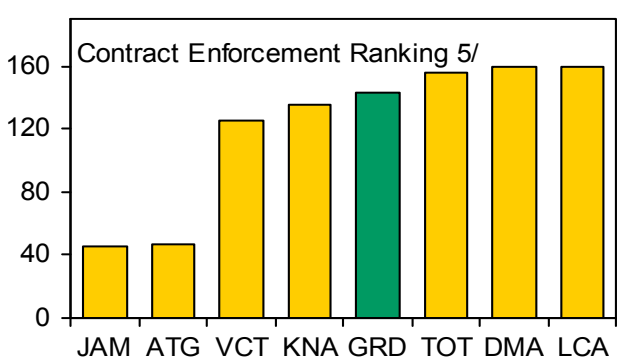

...making it easier to register property and...

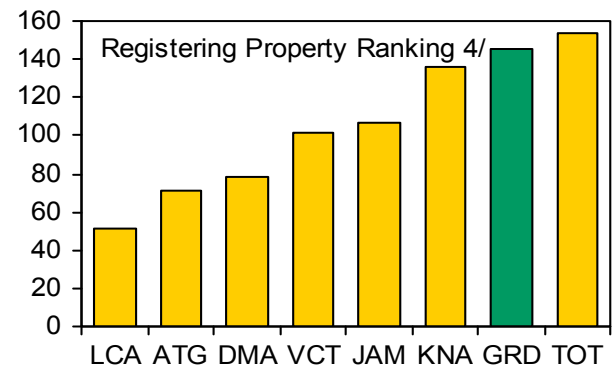

... and the ease of closing a business.

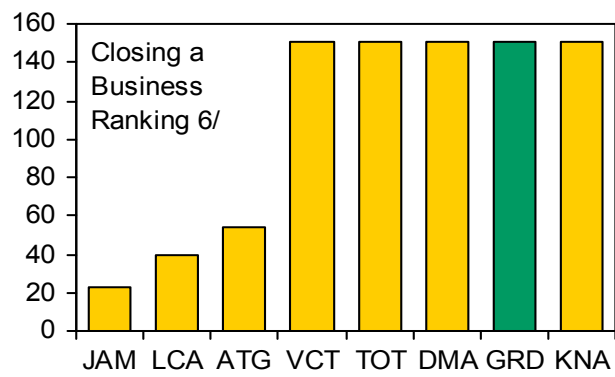

Source: World Bank, Doing Business Indicators (2006).

Note: ATG stands for Antigua and Barbuda, DMA stands for Dominica, GRD stands for Grenada, JAM stands for Jamaica, KNA stands for St. Kitts and Nevis, LCA stands for St. Lucia, TOT stands for Trinidad and Tobago and VCT stands for St. Vincent and the Grenadines.

$1 /$ Smaller numbers represent greater ease in doing business. The indicators are comparable across 175 economies.

$2 /$ This is an overall indicator that captures the regulatory costs of doing business; it can be used to analyze specific regulations that enhance or constrain investment, productivity, and growth.

$3 /$ This topic identifies the bureaucratic and legal steps an entrepreneur must complete to incorporate and register a new firm. It examines the procedures, time, and cost involved in launching a commercial or industrial firm with up to 50 employees and start-up capital of 10 times the economy's per-capita gross national income.

4/ This topic examines the steps, time, and cost involved in registering property, assuming a standardized case of an entrepreneur who wants to purchase land and a building in the largest business city -already registered and free of title dispute.

$5 /$ This topic looks at the efficiency of contract enforcement by following the evolution of a sale of goods dispute and tracking the time, cost, and number of procedures involved from the moment the plaintiff files the lawsuit until actual payment.

6/ This topic identifies weaknesses in existing bankruptcy laws and the main procedural and administrative bottlenecks in the bankruptcy process. 
investor commitments to major tourism projects; putting in place targeted social safety nets; and undertaking work on a PRS to advance social development.

41. Major challenges remain, however, with the DSA indicating that Grenada is at high risk of debt distress. Fiscal slippages over the past year or so have gone against the attempts to place debt on a sustainable trajectory. The resulting increase in debt has eroded the room for maneuver in case of further natural disasters, trade shocks, or financial sector instability. Moreover, current fiscal policies, if continued, would imply that the debt situation would remain unsustainable.

42. Fiscal consolidation remains the cornerstone underpinning debt sustainability. If the government were to pursue a front-loaded fiscal adjustment, it could reach its targeted debt ratio of 60 percent of GDP by 2017, still three years ahead of the ECCB's target date for ECCU members to achieve that ratio. An important element of this scenario is the use of the expected substantial divestment proceeds from sales of land and shares this year to pay down expensive debt, rather than to finance additional budgetary expenditures. In contrast, a scenario based on current fiscal plans - including the use of half of all divestment proceeds to finance capital expenditure in 2007-would imply that the targeted debt ratio would only be reached by 2025 , and with a weaker government net asset position.

\section{Enhancing public financial management will be critical to achieve the fiscal}

goals. Crucially, there is a need to clear arrears as soon as possible and avoid further reliance on unsustainable financing. A track record of budgetary discipline will be important to bolster investor confidence and improve Grenada's credit rating. Structural measures to underpin fiscal consolidation include improving the efficiency of the tax system (supported by a timely VAT introduction), enhancing the effectiveness of public spending, and modernizing the public service. The authorities are taking steps to improve expenditure control and strengthen capacity to screen and prioritize capital projects.

\section{Strengthening the health of the financial sector should be a top priority. The} issue of the unregulated bank should be addressed without delay. First steps would be to conduct an independent assessment of the bank to determine its financial condition and find an approach, consistent with the domestic legal framework, to supervise the bank. Regarding the nonbank financial sector, the authorities are to be commended for strengthening their supervisory framework, including plans to amend the GARFIN Act to address emerging risks in the insurance sector and broaden regulatory coverage to new financial entities. Although Grenada has a comprehensive AML/CFT framework in place, some of the recent financial sector developments also underscore the importance of strengthening this framework's effectiveness to deal with potential risks of ML/FT activities.

45. The government rightly places great emphasis on reducing vulnerabilities. The authorities' strategy to reduce natural disaster-related risks is welcome. It includes 
strengthening Building Code enforcement, enacting a new Insurance Act, and participating in the CCRIF. In light of Grenada's heavy dependence on tourism, the government is also aiming to diversify the economic base with the help of its National Export Strategy. Bolstering the government's financial reputation is also crucial to ensuring solid access to credit markets and to continued FDI flows in light of large domestic and external financing needs for the foreseeable future.

46. External competitiveness does not currently appear to be an issue in Grenada. The real effective exchange rate is at its lowest point in more than two decades, supported by sustained low inflation and the EC dollar's depreciation against the currencies of trading partners. Indirect indicators, including tourism sector developments, also suggest the real exchange rate level is broadly competitive. Looking ahead, however, fiscal consolidation will be key to supporting competitiveness and the sustainability of the currency board arrangement.

47. The structural reform agenda needs to be advanced to maintain the growth momentum and support competitiveness. Ultimately, the greatest challenge facing Grenada is creating the conditions for strong, sustainable, private-sector-led growth in a highly competitive global environment, which would also be key to addressing the social agenda. Wide-ranging reforms - including setting up a one-stop shop for investors, reforming the tax concessions regime, strengthening capacity to evaluate capital projects, and developing a PRS - have been initiated, but the pace of implementation needs to be stepped up to fully reap the benefits of these early efforts. With investors' high level of interest in Grenada at present, this is an opportune time to push through the reforms to improve the business climate.

48. Progress with fiscal consolidation, financial sector supervision (most crucially of the unregulated bank), and the structural reform agenda would also set the stage for moving forward with the first review under the PRGF program. Completing the review could also unlock much-needed grants and concessional financing and facilitate continued support from Paris Club creditors. This additional external support would reinforce the authorities' efforts to advance their homegrown economic program.

49. While data provision is generally adequate for surveillance purposes, better statistics are needed to support effective economic management. Significant improvements in coverage and timeliness are needed to support policy analysis, policymaking, and informed public debate. Data that need strengthening include those for national accounts, labor markets, tourism, balance of payments, debt, and public enterprises.

50. Notwithstanding the above challenges, the economic outlook for Grenada is favorable. Growth prospects are promising, as agriculture continues to recover and the new tourism projects come on stream, raising Grenada's profile as an upmarket tourist 
destination. These developments, combined with progress with the government's reform objectives, should lay the foundation for strong, sustainable growth in the years ahead.

51. It is proposed that the next Article IV consultation take place in accordance with the July 15, 2002 decision on consultation cycles. 
Table 1. Grenada: Selected Economic and Financial Indicators, 2003-09

Rank in UNDP Human Development Index out of 177 countries (2006)

Life expectancy at birth in years (2004) GDP per capita in US\$ (2006)
Infant mortality rate per '000 births (2003)

Adult illiteracy rate in percent (2004)

Poverty headcount index (2000)

\begin{tabular}{llllllllll}
\hline & 2003 & 2004 & 2005 & & Prog. & Prel. & & \multicolumn{2}{c}{ Projections 1/ } \\
\hline
\end{tabular}

(Annual percentage change; unless otherwise specified)

\begin{tabular}{|c|c|c|c|c|c|c|c|c|}
\hline $\begin{array}{l}\text { National income and prices } \\
\text { Real GDP }\end{array}$ & 6.4 & -6.5 & 12.7 & 6.5 & 0.7 & 3.0 & 4.0 & 4.0 \\
\hline GDP detlator & 0.9 & 4.2 & 2.9 & 4.6 & 3.0 & 2.4 & 2.0 & 2.0 \\
\hline \multicolumn{9}{|l|}{ Consumer prices } \\
\hline End-of-year & 1.6 & 2.5 & 5.8 & 2.0 & 1.7 & 2.0 & 2.0 & 2.0 \\
\hline Period average & 2.2 & 2.3 & 3.5 & 4.6 & 4.2 & 2.4 & 2.0 & 2.0 \\
\hline \multicolumn{9}{|l|}{ External sector } \\
\hline Merchandise Exports, t.o.b. & 10.0 & -18.9 & -5.5 & 0.6 & -15.6 & 14.5 & 8.8 & 10.3 \\
\hline Merchandise Imports, c.i.f. & 25.1 & 3.9 & 20.0 & -3.4 & -8.0 & 5.0 & 5.4 & 4.4 \\
\hline Merchandise Export volume 2/ & -2.0 & -25.6 & -15.8 & -0.6 & -15.2 & 17.1 & 14.9 & 13.3 \\
\hline Merchandise Import volume 21 & 12.0 & -8.5 & 11.2 & -5.0 & -16.1 & 1.7 & 5.1 & 5.8 \\
\hline Current account balance (including grants; in percent of GDP) & -32.2 & -12.4 & -24.9 & -32.8 & -23.9 & -24.9 & -24.9 & -21.9 \\
\hline Ierms of trade (deterioration -) & -2.9 & -10.5 & -0.7 & -0.5 & -9.2 & -5.4 & -5.3 & -1.8 \\
\hline Real effective exchange rate (end of period, depreciation -) & -5.2 & -3.5 & 5.6 & $\ldots$ & -4.6 & $\ldots$ & $\ldots$ & $\ldots$ \\
\hline \multicolumn{9}{|l|}{ Banking system } \\
\hline Net foreign assets $3 /$ & 5.8 & 17.9 & -19.3 & -2.2 & -6.4 & 0.0 & 0.5 & -0.8 \\
\hline Net domestic assets $3 /$ & 2.2 & -0.2 & 18.3 & 10.1 & 7.3 & 3.9 & 4.6 & 6.0 \\
\hline \multicolumn{9}{|l|}{ Of which } \\
\hline Credit to public sector (net) $3 /$ & 2.3 & -6.5 & -1.1 & 0.0 & 0.2 & -1.5 & -1.4 & 0.5 \\
\hline Credit to private sector $3 /$ & 3.1 & 5.0 & 6.2 & 8.5 & 9.2 & 4.6 & 5.9 & 5.5 \\
\hline Money and quasi-money (M'2) & 8.0 & 17.7 & -1.0 & 7.8 & 0.9 & 3.9 & 5.1 & 5.2 \\
\hline Weighted average deposit rate (in percent) & 3.4 & 2.8 & 2.8 & $\ldots$ & 3.0 & $\ldots$ & $\ldots$ & $\ldots$ \\
\hline Weighted average lending rate (in percent) & 12.4 & 10.0 & 10.2 & $\ldots$ & 9.7 & $\ldots$ & $\ldots$ & ... \\
\hline
\end{tabular}

(In percent of GDP)

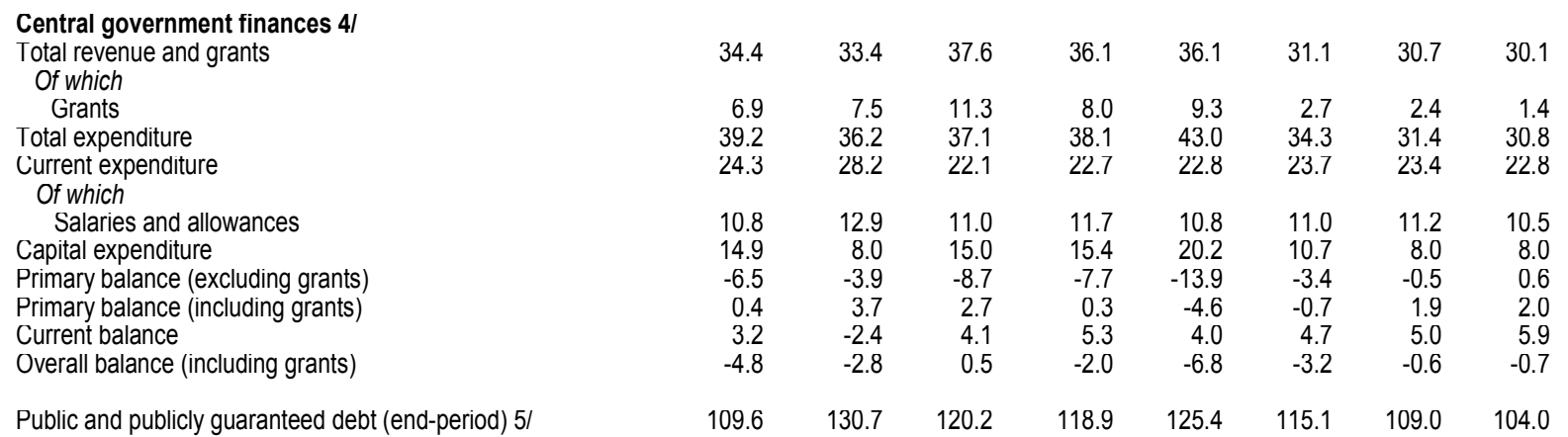

(In millions of U.S. dollars; unless otherwise specified)

\begin{tabular}{|c|c|c|c|c|c|c|c|c|}
\hline $\begin{array}{l}\text { Gross international reserves of the ECCB, end-of-period } \\
\text { In percent of broad money in all ECCU countries }\end{array}$ & $\begin{array}{r}539.9 \\
19.8\end{array}$ & $\begin{array}{r}632.4 \\
20.5\end{array}$ & $\begin{array}{r}600.8 \\
17.9\end{array}$ & $\ldots$ & $\begin{array}{r}696.0 \\
19.7\end{array}$ & $\ldots$ & $\begin{array}{l}\cdots \\
\ldots\end{array}$ & $\ldots$ \\
\hline Nominal GDP & 445.3 & 433.0 & 508.2 & 519.3 & 524.9 & 554.3 & 593.5 & 631.4 \\
\hline
\end{tabular}

Sources: Ministry of Finance; Eastern Caribbean Central Bank; United Nations, Human Development Report 2006; World Bank, WDI 2006; and Fund statt estimates and projections.

1/ Based on the baseline (current policies) scenario.

2/ Does not include goods procured in ports by carriers.

3/ As a percent of broad money at the beginning of the year.

4/ Measured using above-the-line information.

$5 /$ Includes debt of PetroCaribe Grenada Ltd. 
Table 2a. Grenada: Medium-Term Central Government Finances, Baseline Scenario, 2003-09 1/

(In millions of Eastern Caribbean dollars, unless noted otherwise)

\begin{tabular}{|c|c|c|c|c|c|c|c|c|c|}
\hline & & & Est. & Prog. & Prel. & Budget & & jections & \\
\hline & 2003 & 2004 & 2005 & 2006 & & 2007 & 2007 & 2008 & 2009 \\
\hline Total revenue and grants & 413.2 & 390.7 & 515.7 & 505.6 & 511.9 & 536.4 & 465.5 & 492.6 & 513.2 \\
\hline Total revenue & 330.3 & 302.5 & 360.1 & 392.8 & 379.7 & 441.2 & 424.8 & 454.7 & 488.7 \\
\hline Current revenue & 330.0 & 301.2 & 359.8 & 392.3 & 379.6 & 441.1 & 424.7 & 454.6 & 488.6 \\
\hline Tax revenue & 298.3 & 278.8 & 344.0 & 362.1 & 353.5 & 407.5 & 387.7 & 422.7 & 454.0 \\
\hline Taxes on income and protits & 47.5 & 43.0 & 57.7 & 67.2 & 56.0 & 65.2 & 65.3 & 77.4 & 80.7 \\
\hline Taxes on property 21 & 17.0 & 16.4 & 15.4 & 17.1 & 22.6 & 32.1 & 31.0 & 20.7 & 24.1 \\
\hline Taxes on domestic goods and services $3 /$ & 59.0 & 52.4 & 60.0 & 69.0 & 69.0 & 115.3 & 69.9 & 162.4 & 203.5 \\
\hline Taxes on international transactions & 174.8 & 167.1 & 210.9 & 208.9 & 205.9 & 194.9 & 221.7 & 162.3 & 145.7 \\
\hline Nontax revenue & 31.8 & 22.3 & 15.8 & 30.1 & 26.0 & 33.6 & 36.9 & 31.8 & 34.6 \\
\hline Capital revenue & 0.3 & 1.3 & 0.3 & 0.5 & 0.1 & 0.1 & 0.1 & 0.1 & 0.1 \\
\hline Grants & 82.9 & 88.2 & 155.6 & 112.8 & 132.2 & 95.2 & 40.7 & 38.0 & 24.5 \\
\hline Total expenditure & 470.8 & 423.4 & 508.9 & 534.2 & 608.9 & 576.2 & 514.1 & 503.0 & 524.4 \\
\hline Current expenditure & 291.6 & 329.6 & 303.0 & 318.1 & 323.1 & 350.7 & 354.1 & 374.8 & 388.0 \\
\hline Current primary expenditure & 229.2 & 253.8 & 273.1 & 285.1 & 291.6 & 314.1 & 316.1 & 334.3 & 342.2 \\
\hline Salaries and allowances & 130.4 & 150.3 & 150.3 & 164.1 & 152.5 & 167.2 & 164.9 & 179.5 & 179.5 \\
\hline Wages and salaries & 118.4 & 135.0 & 134.7 & 145.2 & 135.3 & 147.3 & 147.2 & 161.4 & 161.1 \\
\hline Personnel allowances & 12.0 & 15.3 & 15.6 & 18.9 & 17.1 & 19.9 & 17.7 & 18.1 & 18.5 \\
\hline Goods and services & 40.5 & 48.0 & 68.2 & 58.4 & 71.1 & 69.5 & 72.4 & 76.7 & 81.4 \\
\hline Interest & 62.5 & 75.8 & 29.9 & 33.0 & 31.6 & 36.6 & 38.0 & 40.5 & 45.8 \\
\hline Domestic & 17.2 & 21.1 & 15.8 & 9.3 & 9.9 & 12.2 & 11.7 & 11.1 & 11.3 \\
\hline Foreign & 45.2 & 54.7 & 14.0 & 23.7 & 21.6 & 24.4 & 26.2 & 29.4 & 34.6 \\
\hline Transfers and subsidies & 58.3 & 55.5 & 54.6 & 62.6 & 68.0 & 77.4 & 78.9 & 78.1 & 81.3 \\
\hline Statutory authorities and state enterprises & 0.0 & 0.0 & 0.0 & 0.0 & 0.0 & 0.0 & 0.0 & 0.0 & 0.0 \\
\hline Private enterprises & 6.5 & 0.0 & 0.0 & 0.0 & 0.0 & 0.0 & 0.0 & 0.0 & 0.0 \\
\hline Grants and subventions & 19.7 & 17.8 & 21.4 & 27.9 & 25.2 & 32.4 & 32.4 & 33.0 & 33.7 \\
\hline Transfers abroad (contributions) & 6.5 & 5.2 & 4.4 & 4.6 & 9.4 & 11.4 & 11.3 & 8.0 & 8.5 \\
\hline Transters to Statutory Boards & 0.5 & 0.8 & 0.6 & 0.6 & 0.5 & 0.9 & 0.8 & 0.9 & 0.9 \\
\hline Transters to households & 25.1 & 31.8 & 28.2 & 29.5 & 32.9 & 32.6 & 34.4 & 36.3 & 38.2 \\
\hline Capital expenditure & 179.1 & 93.8 & 206.0 & 216.1 & 285.8 & 225.5 & 160.0 & 128.2 & 136.4 \\
\hline Current balance & 38.4 & -28.4 & 56.8 & 74.2 & 56.5 & 90.4 & 70.6 & 79.8 & 100.6 \\
\hline Primary balance (excluding grants) & -78.0 & -45.0 & -119.0 & -108.5 & -197.6 & -98.4 & -51.3 & -7.8 & 10.2 \\
\hline Primary balance (including grants) & 4.9 & 43.1 & 36.6 & 4.4 & -65.4 & -3.2 & -10.6 & 30.1 & 34.6 \\
\hline Overall balance (excluding grants) & -140.5 & -120.8 & -148.8 & -141.5 & -229.2 & -135.0 & -89.3 & -48.3 & -35.6 \\
\hline Overall balance (including grants) & -57.6 & -32.7 & 6.7 & -28.7 & -97.0 & -39.8 & -48.6 & -10.3 & -11.2 \\
\hline Statistical discrepancy 4/ & -56.0 & -19.1 & 0.2 & 0.0 & -27.7 & 0.0 & 0.0 & 0.0 & 0.0 \\
\hline Financing & 113.5 & 51.8 & -6.5 & 28.7 & 124.6 & 30.7 & 48.6 & 10.3 & 11.2 \\
\hline Net external financing & 39.7 & 67.9 & 25.7 & 61.1 & 54.8 & -5.3 & 4.8 & 31.3 & 2.6 \\
\hline Net amortisation & 39.7 & 111.7 & 25.7 & 61.1 & 54.8 & -5.3 & 2.9 & 23.0 & -6.7 \\
\hline Disbursments & 66.6 & 157.5 & 40.0 & 83.2 & 73.8 & 26.0 & 34.2 & 62.9 & 31.7 \\
\hline Amortisation & -26.9 & -45.9 & -14.3 & -22.0 & -19.0 & -31.3 & -31.3 & -39.9 & -38.4 \\
\hline Change in government assets & 0.0 & -43.7 & 0.0 & 0.0 & 0.0 & 0.0 & 0.0 & 0.0 & 0.0 \\
\hline PetroCaribe Grenada Ltd. & $\ldots$ & $\ldots$ & $\ldots$ & & $\ldots$ & 0.0 & 1.9 & 8.3 & 9.4 \\
\hline Net domestic financing & 73.6 & -38.1 & -32.2 & -32.5 & 30.2 & 0.0 & -32.7 & -20.9 & 8.5 \\
\hline Divestment/privatization proceeds & 0.3 & 0.0 & 0.0 & 0.0 & 8.8 & 35.9 & 107.3 & 0.0 & 0.0 \\
\hline Arrears & 0.0 & 22.0 & 0.0 & 0.0 & 30.8 & 0.0 & -30.8 & 0.0 & 0.0 \\
\hline Financing gap & 0.0 & 0.0 & 0.0 & 0.0 & 0.0 & 9.1 & 0.0 & 0.0 & 0.0 \\
\hline Memorandum items: & & & & & & & & & \\
\hline Total public and publicly guaranteed debt $5 /$ & 1,318 & 1,528 & 1,649 & 1,666 & 1,778 & 1,778 & 1,722 & 1,746 & 1,773 \\
\hline Nominal GDP (market prices) & 1,202 & 1,169 & 1,372 & 1,402 & 1,417 & 1,497 & 1,497 & 1,602 & 1,705 \\
\hline Real GDP growth (percent change) & 6.4 & -6.5 & 12.7 & 6.5 & 0.7 & 3.0 & 3.0 & 4.0 & 4.0 \\
\hline $\mathrm{CPI}$ (average, percent change) & 2.2 & 2.3 & 3.5 & 4.6 & 3.8 & 2.0 & 2.4 & 2.0 & 2.0 \\
\hline
\end{tabular}

Sources: Ministry of Finance; and Fund staff estimates and projections.

$1 /$ After debt restructuring in 2005.

2/ Taxes on property include both property taxes and transfer taxes. Property taxes are expected to increase starting in 2008 due to the program to revalue real estate. Transfer taxes are expected to return to their recent historical trend after a jump in 2007 due to one-off sale of assets.

3/ The sharp drop in taxes on international transactions and the concurrent rise in taxes on domestic goods and services reflect the expected introduction of the VAT in 2008.

4/ Difference between overall balance and identified financing.

$5 /$ Includes debt of PetroCaribe Grenada Ltd. 
Table 2b. Grenada: Medium-Term Central Government Finances, Baseline Scenario, 2003-09 1/

(In percent of GDP, unless noted otherwise)

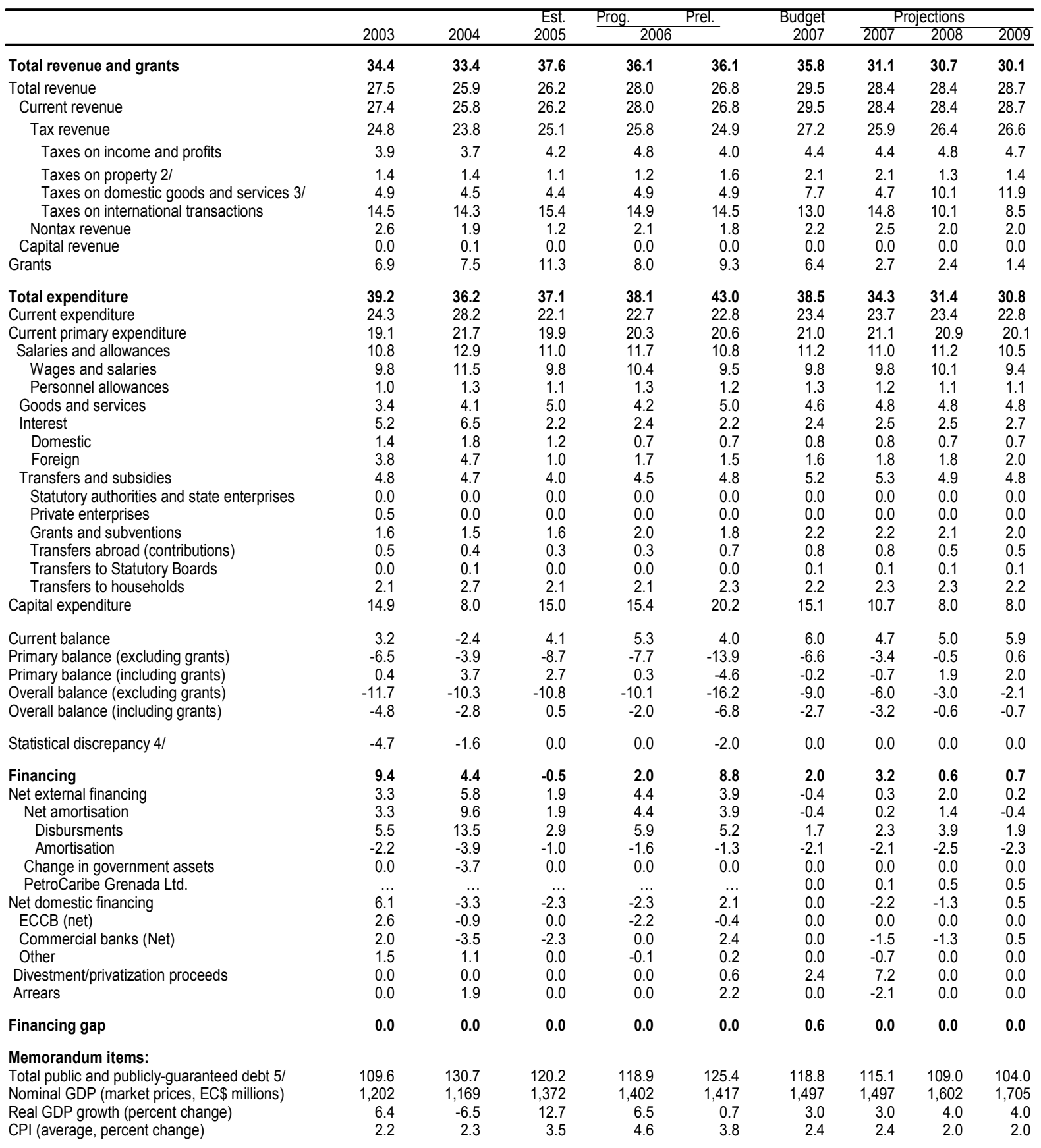

Sources: Ministry of Finance; and Fund staff estimates and projections.

$1 /$ After debt restructuring in 2005.

2/ Taxes on property include both property taxes and transfer taxes. Property taxes are expected to increase starting in 2008 due to the program to revalue real estate. Transfer taxes are expected to return to their recent historical trend after a jump in 2007 due to one-off sale of assets.

$3 /$ The sharp drop in taxes on international transactions and the concurrent rise in taxes on domestic goods and services reflect the expected introduction of the VAT in 2008.

4/ Difference between overall balance and identified financing.

5/ Includes debt of PetroCaribe Grenada Ltd. 
Table 2c. Grenada: Medium-Term Central Government Finances, Active Scenario, 2003-09 1/

(In millions of Eastern Caribbean dollars, unless noted otherwise)

\begin{tabular}{|c|c|c|c|c|c|c|c|c|c|}
\hline & & & Est. & Prog. & Prel. & Budget & & jections & \\
\hline & 2003 & 2004 & 2005 & 2006 & & 2007 & 2007 & 2008 & 2009 \\
\hline Total revenue and grants & 413.2 & 390.7 & 515.7 & 505.6 & 511.9 & 536.4 & 483.3 & 503.9 & 524.5 \\
\hline Total revenue & 330.3 & 302.5 & 360.1 & 392.8 & 379.7 & 441.2 & 427.7 & 454.8 & 488.9 \\
\hline Current revenue & 330.0 & 301.2 & 359.8 & 392.3 & 379.6 & 441.1 & 427.6 & 454.7 & 488.7 \\
\hline Tax revenue & 298.3 & 278.8 & 344.0 & 362.1 & 353.5 & 407.5 & 387.7 & 422.7 & 454.0 \\
\hline Taxes on income and protits & 47.5 & 43.0 & 57.7 & 67.2 & 56.0 & 65.2 & 65.3 & 77.4 & 80.7 \\
\hline Taxes on property 21 & 17.0 & 16.4 & 15.4 & 17.1 & 22.6 & 32.1 & 31.0 & 20.7 & 24.1 \\
\hline Taxes on domestic goods and services $3 /$ & 59.0 & 52.4 & 60.0 & 69.0 & 69.0 & 115.3 & 69.9 & 162.4 & 203.5 \\
\hline Taxes on international transactions & 174.8 & 167.1 & 210.9 & 208.9 & 205.9 & 194.9 & 221.7 & 162.3 & 145.7 \\
\hline Nontax revenue & 31.8 & 22.3 & 15.8 & 30.1 & 26.0 & 33.6 & 39.9 & 31.9 & 34.7 \\
\hline Capital revenue & 0.3 & 1.3 & 0.3 & 0.5 & 0.1 & 0.1 & 0.1 & 0.1 & 0.1 \\
\hline Grants & 82.9 & 88.2 & 155.6 & 112.8 & 132.2 & 95.2 & 55.6 & 49.1 & 35.6 \\
\hline Total expenditure & 470.8 & 423.4 & 508.9 & 534.2 & 608.9 & 576.2 & 464.4 & 484.4 & 500.5 \\
\hline Current expenditure & 291.6 & 329.6 & 303.0 & 318.1 & 323.1 & 350.7 & 335.2 & 356.2 & 364.1 \\
\hline Current primary expenditure & 229.2 & 253.8 & 273.1 & 285.1 & 291.6 & 314.1 & 297.2 & 316.4 & 319.3 \\
\hline Salaries and allowances & 130.4 & 150.3 & 150.3 & 164.1 & 152.5 & 167.2 & 164.9 & 179.5 & 179.5 \\
\hline Wages and salaries & 118.4 & 135.0 & 134.7 & 145.2 & 135.3 & 147.3 & 147.2 & 161.4 & 161.1 \\
\hline Personnel allowances & 12.0 & 15.3 & 15.6 & 18.9 & 17.1 & 19.9 & 17.7 & 18.1 & 18.5 \\
\hline Goods and services & 40.5 & 48.0 & 68.2 & 58.4 & 71.1 & 69.5 & 66.7 & 68.0 & 69.4 \\
\hline Interest & 62.5 & 75.8 & 29.9 & 33.0 & 31.6 & 36.6 & 38.0 & 39.8 & 44.8 \\
\hline Domestic & 17.2 & 21.1 & 15.8 & 9.3 & 9.9 & 12.2 & 11.7 & 10.3 & 11.1 \\
\hline Foreign & 45.2 & 54.7 & 14.0 & 23.7 & 21.6 & 24.4 & 26.3 & 29.5 & 33.7 \\
\hline Transters and subsidies & 58.3 & 55.5 & 54.6 & 62.6 & 68.0 & 77.4 & 65.6 & 68.9 & 70.4 \\
\hline Statutory authorities and state enterprises & 0.0 & 0.0 & 0.0 & 0.0 & 0.0 & 0.0 & 0.0 & 0.0 & 0.0 \\
\hline Private enterprises & 6.5 & 0.0 & 0.0 & 0.0 & 0.0 & 0.0 & 0.0 & 0.0 & 0.0 \\
\hline Grants and subventions & 19.7 & 17.8 & 21.4 & 27.9 & 25.2 & 32.4 & 21.0 & 22.4 & 23.4 \\
\hline Transfers abroad (contributions) & 6.5 & 5.2 & 4.4 & 4.6 & 9.4 & 11.4 & 9.4 & 9.4 & 7.9 \\
\hline Transfers to Statutory Boards & 0.5 & 0.8 & 0.6 & 0.6 & 0.5 & 0.9 & 0.8 & 0.9 & 0.9 \\
\hline Transters to households & 25.1 & 31.8 & 28.2 & 29.5 & 32.9 & 32.6 & 34.4 & 36.3 & 38.2 \\
\hline Capital expenditure & 179.1 & 93.8 & 206.0 & 216.1 & 285.8 & 225.5 & 129.2 & 128.2 & 136.4 \\
\hline Current balance & 38.4 & -28.4 & 56.8 & 74.2 & 56.5 & 90.4 & 92.4 & 98.5 & 124.6 \\
\hline Primary balance (excluding grants) & -78.0 & -45.0 & -119.0 & -108.5 & -197.6 & -98.4 & 1.3 & 10.2 & 33.2 \\
\hline Primary balance (including grants) & 4.9 & 43.1 & 36.6 & 4.4 & -65.4 & -3.2 & 56.9 & 59.3 & 68.8 \\
\hline Overall balance (excluding grants) & -140.5 & -120.8 & -148.8 & -141.5 & -229.2 & -135.0 & -36.7 & -29.6 & -11.6 \\
\hline Overall balance (including grants) & -57.6 & -32.7 & 6.7 & -28.7 & -97.0 & -39.8 & 18.9 & 19.5 & 24.0 \\
\hline Statistical discrepancy 4/ & -56.0 & -19.1 & 0.2 & 0.0 & -27.7 & 0.0 & 0.0 & 0.0 & 0.0 \\
\hline Financing & 113.5 & 51.8 & -6.5 & 28.7 & 124.6 & 30.7 & -18.9 & -19.5 & -24.0 \\
\hline Net external financing & 39.7 & 67.9 & 25.7 & 61.1 & 54.8 & -5.3 & -36.1 & -7.2 & -10.8 \\
\hline Net amortisation & 39.7 & 111.7 & 25.7 & 61.1 & 54.8 & -5.3 & -38.1 & -15.5 & -20.1 \\
\hline Disbursments & 66.6 & 157.5 & 40.0 & 83.2 & 73.8 & 26.0 & 46.9 & 35.7 & 36.1 \\
\hline Amortisation & -26.9 & -45.9 & -14.3 & -22.0 & -19.0 & -31.3 & -84.9 & -51.2 & -56.2 \\
\hline Change in government assets & 0.0 & -43.7 & 0.0 & 0.0 & 0.0 & 0.0 & 0.0 & 0.0 & 0.0 \\
\hline PetroCaribe Grenada Ltd. & & & & & & 0.0 & 1.9 & 8.3 & 9.4 \\
\hline Net domestic financing & 73.6 & -38.1 & -32.2 & -32.5 & 30.2 & 0.0 & -59.2 & -12.3 & -13.3 \\
\hline Divestment/privatization proceeds & 0.3 & 0.0 & 0.0 & 0.0 & 8.8 & 35.9 & 107.3 & 0.0 & 0.0 \\
\hline Arrears & 0.0 & 22.0 & 0.0 & 0.0 & 30.8 & 0.0 & -30.8 & 0.0 & 0.0 \\
\hline Financing gap & 0.0 & 0.0 & 0.0 & 0.0 & 0.0 & 9.1 & 0.0 & 0.0 & 0.0 \\
\hline Memorandum items: & & & & & & & & & \\
\hline Total public and publicly-guaranteed debt $5 /$ & $1,318.2$ & 1,528 & 1,649 & 1,666 & 1,778 & 1,778 & 1,670 & 1,664 & 1,656 \\
\hline Nominal GDP (market prices) & 1,202 & 1,169 & 1,372 & 1,402 & 1,417 & 1,497 & 1,497 & 1,602 & 1,705 \\
\hline Real GDP growth (percent change) & 6.4 & -6.5 & 12.7 & 6.5 & 0.7 & 3.0 & 3.0 & 4.0 & 4.0 \\
\hline $\mathrm{CPI}$ (average, percent change) & 2.2 & 2.3 & 3.5 & 4.6 & 3.8 & 2.0 & 2.4 & 2.0 & 2.0 \\
\hline
\end{tabular}

Sources: Ministry of Finance; and Fund staff estimates and projections.

$1 /$ After debt restructuring in 2005.

2/ Taxes on property include both property taxes and transfer taxes. Property taxes are expected to increase starting in 2008 due to the program to revalue real estate. Transfer taxes are expected to return to their recent historical trend after a jump in 2007 due to one-off sale of assets.

$3 /$ The sharp drop in taxes on international transactions and the concurrent rise in taxes on domestic goods and services reflect the expected introduction of the VAT in 2008.

4/ Difference between overall balance and identified financing.

5/ Includes debt of PetroCaribe Grenada Ltd. 
Table 2d. Grenada: Medium-Term Central Government Finances, Active Scenario, 2003-09 1/

(In percent of GDP, unless noted otherwise)

\begin{tabular}{|c|c|c|c|c|c|c|c|c|c|}
\hline \multirow{3}{*}{ Total revenue and grants } & \multirow{3}{*}{$\frac{2003}{34.4}$} & \multirow{3}{*}{$\frac{2004}{33.4}$} & \multirow{3}{*}{$\begin{array}{r}\text { Est. } \\
2005 \\
37.6\end{array}$} & \multirow{2}{*}{$\begin{array}{l}\text { Prog. } \\
2006 \\
\end{array}$} & \multirow[t]{2}{*}{ Prel. } & \multirow{2}{*}{$\begin{array}{r}\text { Budget } \\
2007 \\
\end{array}$} & \multicolumn{3}{|c|}{ Projections } \\
\hline & & & & & & & 2007 & 2008 & 2009 \\
\hline & & & & 36.1 & 36.1 & 35.8 & 32.3 & 31.4 & 30.8 \\
\hline Total revenue & 27.5 & 25.9 & 26.2 & 28.0 & 26.8 & 29.5 & 28.6 & 28.4 & 28.7 \\
\hline Current revenue & 27.4 & 25.8 & 26.2 & 28.0 & 26.8 & 29.5 & 28.6 & 28.4 & 28.7 \\
\hline Tax revenue & 24.8 & 23.8 & 25.1 & 25.8 & 24.9 & 27.2 & 25.9 & 26.4 & 26.6 \\
\hline Taxes on income and profits & 3.9 & 3.7 & 4.2 & 4.8 & 4.0 & 4.4 & 4.4 & 4.8 & 4.7 \\
\hline Taxes on property $2 /$ & 1.4 & 1.4 & 1.1 & 1.2 & 1.6 & 2.1 & 2.1 & 1.3 & 1.4 \\
\hline Taxes on domestic goods and services $3 /$ & 4.9 & 4.5 & 4.4 & 4.9 & 4.9 & 7.7 & 4.7 & 10.1 & 11.9 \\
\hline Taxes on international transactions & 14.5 & 14.3 & 15.4 & 14.9 & 14.5 & 13.0 & 14.8 & 10.1 & 8.5 \\
\hline Nontax revenue & 2.6 & 1.9 & 1.2 & 2.1 & 1.8 & 2.2 & 2.7 & 2.0 & 2.0 \\
\hline Capital revenue & 0.0 & 0.1 & 0.0 & 0.0 & 0.0 & 0.0 & 0.0 & 0.0 & 0.0 \\
\hline Grants & 6.9 & 7.5 & 11.3 & 8.0 & 9.3 & 6.4 & 3.7 & 3.1 & 2.1 \\
\hline Total expenditure & 39.2 & 36.2 & 37.1 & 38.1 & 43.0 & 38.5 & 31.0 & 30.2 & 29.4 \\
\hline Current expenditure & 24.3 & 28.2 & 22.1 & 22.7 & 22.8 & 23.4 & 22.4 & 22.2 & 21.4 \\
\hline Current primary expenditure & 19.1 & 21.7 & 19.9 & 20.3 & 20.6 & 21.0 & 19.9 & 19.7 & 18.7 \\
\hline Salaries and allowances & 10.8 & 12.9 & 11.0 & 11.7 & 10.8 & 11.2 & 11.0 & 11.2 & 10.5 \\
\hline Wages and salaries & 9.8 & 11.5 & 9.8 & 10.4 & 9.5 & 9.8 & 9.8 & 10.1 & 9.4 \\
\hline Personnel allowances & 1.0 & 1.3 & 1.1 & 1.3 & 1.2 & 1.3 & 1.2 & 1.1 & 1.1 \\
\hline Goods and services & 3.4 & 4.1 & 5.0 & 4.2 & 5.0 & 4.6 & 4.5 & 4.2 & 4.1 \\
\hline Interest & 5.2 & 6.5 & 2.2 & 2.4 & 2.2 & 2.4 & 2.5 & 2.5 & 2.6 \\
\hline Domestic & 1.4 & 1.8 & 1.2 & 0.7 & 0.7 & 0.8 & 0.8 & 0.6 & 0.6 \\
\hline Foreign & 3.8 & 4.7 & 1.0 & 1.7 & 1.5 & 1.6 & 1.8 & 1.8 & 2.0 \\
\hline Transfers and subsidies & 4.8 & 4.7 & 4.0 & 4.5 & 4.8 & 5.2 & 4.4 & 4.3 & 4.1 \\
\hline Statutory authorities and state enterprises & 0.0 & 0.0 & 0.0 & 0.0 & 0.0 & 0.0 & 0.0 & 0.0 & 0.0 \\
\hline Private enterprises & 0.5 & 0.0 & 0.0 & 0.0 & 0.0 & 0.0 & 0.0 & 0.0 & 0.0 \\
\hline Grants and subventions & 1.6 & 1.5 & 1.6 & 2.0 & 1.8 & 2.2 & 1.4 & 1.4 & 1.4 \\
\hline Transfers abroad (contributions) & 0.5 & 0.4 & 0.3 & 0.3 & 0.7 & 0.8 & 0.6 & 0.6 & 0.5 \\
\hline Transfers to Statutory Boards & 0.0 & 0.1 & 0.0 & 0.0 & 0.0 & 0.1 & 0.1 & 0.1 & 0.1 \\
\hline Transfers to households & 2.1 & 2.7 & 2.1 & 2.1 & 2.3 & 2.2 & 2.3 & 2.3 & 2.2 \\
\hline Capital expenditure & 14.9 & 8.0 & 15.0 & 15.4 & 20.2 & 15.1 & 8.6 & 8.0 & 8.0 \\
\hline Current balance & 3.2 & -2.4 & 4.1 & 5.3 & 4.0 & 6.0 & 6.2 & 6.1 & 7.3 \\
\hline Primary balance (excluding grants) & -6.5 & -3.9 & -8.7 & -7.7 & -13.9 & -6.6 & 0.1 & 0.6 & 1.9 \\
\hline Primary balance (including grants) & 0.4 & 3.7 & 2.7 & 0.3 & -4.6 & -0.2 & 3.8 & 3.7 & 4.0 \\
\hline Overall balance (excluding grants) & -11.7 & -10.3 & -10.8 & -10.1 & -16.2 & -9.0 & -2.5 & -1.8 & -0.7 \\
\hline Overall balance (including grants) & -4.8 & -2.8 & 0.5 & -2.0 & -6.8 & -2.7 & 1.3 & 1.2 & 1.4 \\
\hline Statistical discrepancy 4/ & -4.7 & -1.6 & 0.0 & 0.0 & -2.0 & 0.0 & 0.0 & 0.0 & 0.0 \\
\hline Financing & 9.4 & 4.4 & -0.5 & 2.0 & 8.8 & 2.0 & -1.3 & -1.2 & -1.4 \\
\hline Net external financing & 3.3 & 5.8 & 1.9 & 4.4 & 3.9 & -0.4 & -2.4 & -0.4 & -0.6 \\
\hline Net amortisation & 3.3 & 9.6 & 1.9 & 4.4 & 3.9 & -0.4 & -2.5 & -1.0 & -1.2 \\
\hline Disbursments & 5.5 & 13.5 & 2.9 & 5.9 & 5.2 & 1.7 & 3.1 & 2.2 & 2.1 \\
\hline Amortisation & -2.2 & -3.9 & -1.0 & -1.6 & -1.3 & -2.1 & -5.7 & -3.2 & -3.3 \\
\hline Change in government assets & 0.0 & -3.7 & 0.0 & 0.0 & 0.0 & 0.0 & 0.0 & 0.0 & 0.0 \\
\hline PetroCaribe Grenada Ltd. & & & & & & 0.0 & 0.1 & 0.5 & 0.5 \\
\hline Net domestic financing & 6.1 & -3.3 & -2.3 & -2.3 & 2.1 & 0.0 & -4.0 & -0.8 & -0.8 \\
\hline ECCB (net) & 2.6 & -0.9 & 0.0 & -2.2 & -0.4 & 0.0 & -1.0 & 0.0 & 0.0 \\
\hline Commercial banks (Net) & 2.0 & -3.5 & -2.3 & 0.0 & 2.4 & 0.0 & -1.5 & -0.8 & -0.9 \\
\hline Other & 1.5 & 1.1 & 0.0 & -0.1 & 0.2 & 0.0 & -1.4 & 0.0 & 0.2 \\
\hline Divestment/privatization proceeds & 0.0 & 0.0 & 0.0 & 0.0 & 0.6 & 2.4 & 7.2 & 0.0 & 0.0 \\
\hline Arrears & 0.0 & 1.9 & 0.0 & 0.0 & 2.2 & 0.0 & -2.1 & 0.0 & 0.0 \\
\hline Financing gap & 0.0 & 0.0 & 0.0 & 0.0 & 0.0 & 0.6 & 0.0 & 0.0 & 0.0 \\
\hline \multicolumn{10}{|l|}{ Memorandum items: } \\
\hline Total public and publicly-guaranteed debt 5/ & 109.6 & 130.7 & 120.2 & 118.9 & 125.4 & 118.8 & 111.6 & 103.9 & 97.1 \\
\hline Nominal GDP (market prices, EC\$ millions) & 1,202 & 1,169 & 1,372 & 1,402 & 1,417 & 1,497 & 1,497 & 1,602 & 1,705 \\
\hline Real GDP growth (percent change) & 6.4 & -6.5 & 12.7 & 6.5 & 0.7 & 3.0 & 3.0 & 4.0 & 4.0 \\
\hline $\mathrm{CPI}$ (average, percent change) & 2.2 & 2.3 & 3.5 & 4.6 & 3.8 & 2.4 & 2.4 & 2.0 & 2.0 \\
\hline
\end{tabular}

Sources: Ministry of Finance; and Fund staff estimates and projections.

1/ After debt restructuring in 2005.

2/ Taxes on property include both property taxes and transfer taxes. Property taxes are expected to increase starting in 2008 due to the program to revalue real estate. Transfer taxes are expected to return to their recent historical trend after a jump in 2007 due to one-off sale of assets.

$3 /$ The sharp drop in taxes on international transactions and the concurrent rise in taxes on domestic goods and services reflect the expected introduction of the VAT in 2008.

4/ Difference between overall balance and identified financing.

5/ Includes debt of PetroCaribe Grenada Ltd. 
Table 3. Grenada: Summary Accounts of the Banking System, 2004-09

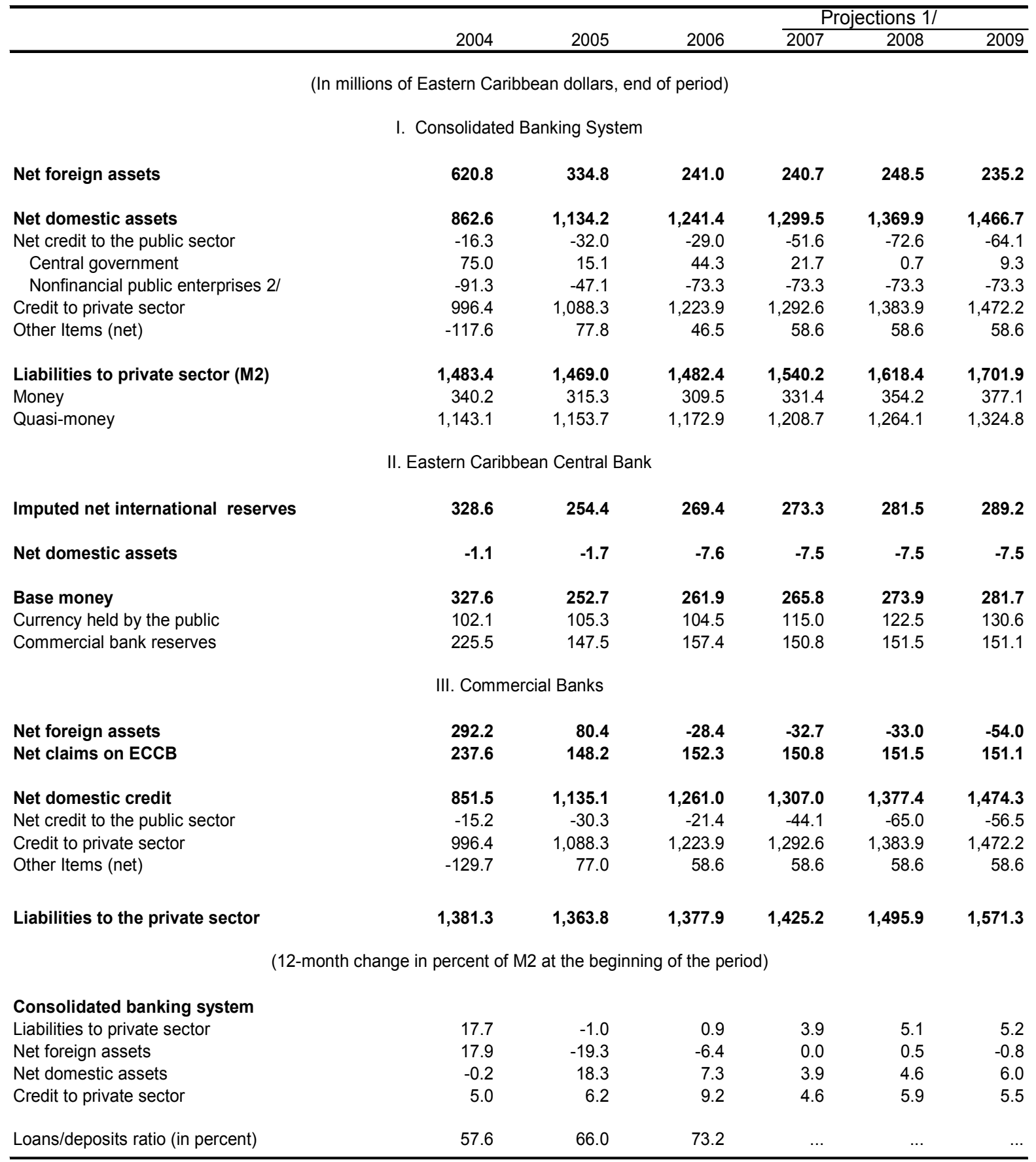

Sources: Eastern Caribbean Central Bank; and Fund staff estimates and projections.

1/ Based on the baseline scenario.

2/ Includes the National Insurance Scheme. 
Table 4. Grenada: Summary Balance of Payments, 2003-12

\begin{tabular}{|c|c|c|c|c|c|c|c|c|c|c|}
\hline & \multirow[b]{2}{*}{2003} & \multirow[b]{2}{*}{2004} & \multirow[b]{2}{*}{2005} & \multirow[b]{2}{*}{2006} & \multicolumn{6}{|c|}{ Projections 1/ } \\
\hline & & & & & 2007 & 2008 & 2009 & 2010 & 2011 & 2012 \\
\hline & \multicolumn{10}{|c|}{ (In millions of U.S. dollars) } \\
\hline Current account balance & -143.5 & -53.6 & -126.5 & -125.7 & -138.0 & -147.9 & -138.4 & -129.7 & -136.4 & -146.5 \\
\hline Exports (f.o.b.) & 45.5 & 36.9 & 34.9 & 29.4 & 33.7 & 36.7 & 40.4 & 45.2 & 48.0 & 50.9 \\
\hline Imports (f.o.b.) & -226.4 & -235.4 & -282.5 & -260.0 & -273.1 & -287.9 & -300.5 & -314.7 & -337.1 & -354.5 \\
\hline Services (net) & 51.0 & 67.2 & 29.2 & 39.0 & 68.1 & 71.7 & 91.2 & 109.1 & 120.5 & 127.5 \\
\hline \multicolumn{11}{|l|}{ Of which } \\
\hline Travel (net) & 95.3 & 74.6 & 68.4 & 92.1 & 124.6 & 130.3 & 151.5 & 171.6 & 187.7 & 198.8 \\
\hline Income (net) & -50.1 & -43.2 & -22.2 & -25.5 & -52.7 & -55.8 & -59.5 & -61.0 & -61.3 & -65.6 \\
\hline Transfers (net) & 36.5 & 120.9 & 114.1 & 91.4 & 86.0 & 87.4 & 90.0 & 91.7 & 93.4 & 95.2 \\
\hline Capital and financial account & 129.4 & 85.9 & 116.1 & 177.9 & 134.7 & 148.2 & 138.6 & 133.0 & 139.3 & 149.5 \\
\hline Capital account (transfers) & 43.2 & 33.2 & 41.0 & 62.7 & 37.1 & 37.7 & 34.4 & 35.3 & 36.7 & 38.2 \\
\hline Financial account & 86.2 & 52.8 & 75.1 & 115.1 & 97.6 & 110.5 & 104.1 & 97.7 & 102.7 & 111.4 \\
\hline \multicolumn{11}{|l|}{ Of which } \\
\hline $\begin{array}{l}\text { Public sector borrowing 2/ } \\
\text { Of which }\end{array}$ & 50.2 & 65.0 & 33.7 & 27.8 & 12.8 & 25.4 & 13.3 & 12.5 & 14.4 & 22.5 \\
\hline Public sector amortization 2/ & -10.5 & -18.6 & -9.0 & -10.7 & -15.3 & -18.5 & -17.9 & -16.6 & -18.2 & -22.8 \\
\hline Direct investment (net) & 89.2 & 54.0 & 48.6 & 51.1 & 84.2 & 89.6 & 94.1 & 98.6 & 103.7 & 109.1 \\
\hline Portfolio investment (net) & 29.9 & 40.4 & 16.4 & -0.1 & 4.1 & 3.7 & 2.4 & 2.4 & 2.4 & 2.4 \\
\hline Other investments (net) & -32.9 & -41.6 & 10.2 & 64.2 & 9.3 & 17.2 & 7.6 & -3.3 & -3.4 & -0.2 \\
\hline Net errors and omissions & -3.0 & 18.0 & -17.0 & -60.3 & 0.0 & 0.0 & 0.0 & 0.0 & 0.0 & 0.0 \\
\hline Overall balance & -17.2 & 50.4 & -27.5 & -8.1 & -3.3 & 0.3 & 0.2 & 3.3 & 2.9 & 3.0 \\
\hline Available financing & 17.2 & -50.4 & 27.5 & 8.1 & 3.3 & -0.3 & -0.2 & -3.3 & -2.9 & -3.0 \\
\hline Change in ımputed reserves & 4.6 & -38.5 & 21.5 & -5.6 & -1.4 & -3.0 & -2.9 & -3.1 & -3.3 & -3.4 \\
\hline IMF purchases & 4.4 & 4.3 & 0.0 & 2.3 & 4.6 & 4.4 & 4.4 & 0.0 & 0.0 & 0.0 \\
\hline IMF repurchases & 0.0 & 0.0 & 0.0 & -1.6 & -1.1 & -2.7 & -2.2 & 0.0 & 0.0 & 0.0 \\
\hline Exceptional financing 2/ & 0.0 & 0.0 & 0.0 & 13.0 & 1.2 & 1.1 & 0.5 & 0.4 & 0.4 & 0.4 \\
\hline Other & 8.2 & -16.2 & 0.0 & 0.0 & 0.0 & 0.0 & 0.0 & 0.0 & 0.0 & 0.0 \\
\hline Financing gap & 0.0 & 0.0 & 0.0 & 0.0 & 0.0 & 0.0 & 0.0 & 0.0 & 0.0 & 0.0 \\
\hline \multicolumn{11}{|l|}{ Memorandum item: } \\
\hline External public sector debt & 355.8 & 415.6 & 437.0 & 457.2 & 458.2 & 466.7 & 464.3 & 460.2 & 456.4 & 456.1 \\
\hline & \multicolumn{10}{|c|}{ (In percent of GDP) } \\
\hline Current account balance & -32.2 & -12.4 & -24.9 & -23.9 & -24.9 & -24.9 & -21.9 & -19.3 & -19.2 & -19.4 \\
\hline Trade balance & 61.1 & 62.9 & 62.4 & 55.1 & 55.3 & 54.7 & 54.0 & 53.7 & 54.2 & 53.8 \\
\hline Exports of goods & 10.2 & 8.5 & 6.9 & 5.6 & 6.1 & 6.2 & 6.4 & 6.8 & 6.8 & 6.8 \\
\hline Imports of goods & -50.8 & -54.3 & -55.6 & -49.5 & -49.3 & -48.5 & -47.6 & -47.0 & -47.4 & -47.0 \\
\hline $\begin{array}{l}\text { Service, income, and transfers } \\
\text { Of which }\end{array}$ & -93.3 & -75.2 & -87.3 & -79.1 & -80.2 & -79.6 & -75.9 & -73.1 & -73.4 & -73.2 \\
\hline Travel (net) & 21.4 & 17.2 & 13.5 & 17.5 & 22.5 & 22.0 & 24.0 & 25.6 & 26.4 & 26.4 \\
\hline Capital and financial account & 29.1 & 19.8 & 22.8 & 33.9 & 24.3 & 25.0 & 21.9 & 19.8 & 19.6 & 19.8 \\
\hline Public sector net borrowing & 8.9 & 10.7 & 4.9 & 3.2 & -0.4 & 1.2 & -0.7 & -0.6 & -0.5 & 0.0 \\
\hline Direct investment & 20.0 & 12.5 & 9.6 & 9.7 & 15.2 & 15.1 & 14.9 & 14.7 & 14.6 & 14.5 \\
\hline Overall balance & -3.9 & 11.6 & -5.4 & -1.5 & -0.6 & 0.0 & 0.0 & 0.5 & 0.4 & 0.4 \\
\hline \multirow[t]{2}{*}{ External public and publicly guaranteed debt } & 79.9 & 96.0 & 86.0 & 87.1 & 82.7 & 78.6 & 73.5 & 68.7 & 64.2 & 60.5 \\
\hline & \multicolumn{10}{|c|}{ (Annual percentage change) } \\
\hline Exports of goods & 10.0 & -18.9 & -5.5 & -15.6 & 14.5 & 8.8 & 10.3 & 11.9 & 6.1 & 6.1 \\
\hline Imports of goods & 25.1 & 3.9 & 20.0 & -8.0 & 5.0 & 5.4 & 4.4 & 4.7 & 7.1 & 5.2 \\
\hline Travel (net) & 17.2 & -21.8 & -8.2 & 34.6 & 35.3 & 4.5 & 16.3 & 13.3 & 9.4 & 5.9 \\
\hline
\end{tabular}

Sources: Eastern Caribbean Central Bank (ECCB); Ministry of Finance; and Fund staff estimates and projections.

$1 /$ Based on the baseline scenario.

2/ Includes amounts rescheduled under the May 2006 Paris Club agreement. 
Table 5. Grenada: Public Sector Debt, 2006

(Year end, in millions of U.S. dollars)

\begin{tabular}{|c|c|c|c|}
\hline & & $\mathrm{Pe}$ & \\
\hline & Stock & Total Debt & GDP \\
\hline Public sector debt $\mathbf{1 /}$ & 658.4 & 100.0 & 125.4 \\
\hline Central government debt & 576.8 & 87.6 & 109.9 \\
\hline Central-government guaranteed debt & 61.1 & 9.3 & 11.7 \\
\hline Other public sector debt & 20.5 & 3.1 & 3.9 \\
\hline External debt & 457.2 & 69.4 & 87.1 \\
\hline A. Central government & 413.3 & 62.8 & 78.7 \\
\hline 1. Multilateral & 136.0 & 20.7 & 25.9 \\
\hline CDB & 84.2 & 12.8 & 16.0 \\
\hline IDA & 27.9 & 4.2 & 5.3 \\
\hline IBRD & 9.0 & 1.4 & 1.7 \\
\hline IMF & 9.5 & 1.4 & 1.8 \\
\hline Other multilateral & 5.4 & 0.8 & 1.0 \\
\hline 2. Official bilateral & 77.9 & 11.8 & 14.8 \\
\hline Paris Club & 16.4 & 2.5 & 3.1 \\
\hline Belgium & 6.7 & 1.0 & 1.3 \\
\hline France & 4.2 & 0.6 & 0.8 \\
\hline Russian Federation & 0.2 & 0.0 & 0.0 \\
\hline United Kingdom & 2.5 & 0.4 & 0.5 \\
\hline United States & 2.8 & 0.4 & 0.5 \\
\hline Non-Paris Club & 61.5 & 9.3 & 11.7 \\
\hline Taiwan Province of China & 20.3 & 3.1 & 3.9 \\
\hline Kuwait & 18.5 & 2.8 & 3.5 \\
\hline Trinidad and Tobago & 17.0 & 2.6 & 3.2 \\
\hline Other bilateral & 5.8 & 0.9 & 1.1 \\
\hline 3. Commercial, total & 199.4 & 30.3 & 38.0 \\
\hline Restructured bonds & 193.5 & 29.4 & 36.9 \\
\hline Unrestructured bonds & 5.8 & 0.9 & 1.1 \\
\hline $\begin{array}{l}\text { B. Central government guaranteed } \\
\text { Of which }\end{array}$ & 23.5 & 3.6 & 4.5 \\
\hline Paris Club & 7.8 & 1.2 & 1.5 \\
\hline C. Other public sector & 20.5 & 3.1 & 3.9 \\
\hline Domestic debt & 201.2 & 30.6 & 38.3 \\
\hline A. Central government & 163.5 & 24.8 & 31.2 \\
\hline Restructured Bonds & 68.1 & 10.3 & 13.0 \\
\hline Unrestructured bonds & 11.0 & 1.7 & 2.1 \\
\hline Treasury bills & 26.5 & 4.0 & 5.0 \\
\hline Commercial bank loans & 24.2 & 3.7 & 4.6 \\
\hline Overdraft & 18.4 & 2.8 & 3.5 \\
\hline Domestic arrears & 14.8 & 2.3 & 2.8 \\
\hline Compensation claims & 0.6 & 0.1 & 0.1 \\
\hline B. Central government guaranteed & 37.7 & 5.7 & 7.2 \\
\hline Memorandum item: & & & \\
\hline Nominal GDP & 524.9 & & \\
\hline
\end{tabular}

Sources: Grenada authorities; and Fund staff estimates.

$1 /$ Includes central government liabilities to the National Insurance Scheme. 
Table 6. Grenada: Indicators of Financial and External Vulnerability, 2001-06

\begin{tabular}{|c|c|c|c|c|}
\hline & 2003 & 2004 & 2005 & $\begin{array}{r}\text { Est. } \\
2006 \\
\end{array}$ \\
\hline \multicolumn{5}{|l|}{ Real sector indicators } \\
\hline Real GDP growth (percent) & 6.4 & -6.5 & 12.7 & 0.7 \\
\hline $\mathrm{CPI}$ inflation (period average, in percent) & 2.2 & 2.3 & 3.5 & 4.2 \\
\hline \multicolumn{5}{|l|}{ Financial sector indicators } \\
\hline Capital adequacy ratio (locally incorporated banks) & 17.7 & 14.9 & 15.3 & 17.5 \\
\hline Liquid assets/total assets & 32.5 & 44.3 & 37.3 & 31.5 \\
\hline Liquid assets/current liabilities & 35.6 & 48.2 & 40.0 & 34.6 \\
\hline Total loans/total deposits & 68.1 & 57.6 & 66.0 & 73.2 \\
\hline Net liquid assets/total deposits & 33.4 & 44.2 & 35.4 & 28.6 \\
\hline Nonperforming loans/total loans & 4.5 & 6.0 & 5.5 & 3.7 \\
\hline Locally incorporated banks & 7.2 & 7.1 & 6.8 & 4.7 \\
\hline Foreign banks & 0.6 & 4.4 & 3.5 & 2.4 \\
\hline Loan loss provision/NPLs & 61.7 & 81.9 & 79.4 & 67.4 \\
\hline Locally incorporated banks & 49.5 & 63.0 & 60.7 & 51.5 \\
\hline Foreign banks $1 /$ & 301.3 & 127.8 & 134.6 & 114.6 \\
\hline Gross government claims/total assets & 13.9 & 11.3 & 11.2 & 11.6 \\
\hline FX deposits/total deposits & 7.3 & 5.6 & 7.8 & 5.8 \\
\hline Net foreign currency exposure/capital (locally incorporated banks) & 116.4 & 221.4 & 138.4 & 101.4 \\
\hline (Pre-tax) return on average assets & 2.8 & 0.5 & 0.7 & 2.5 \\
\hline Broad money (percent change, 12-month basis) & 8.0 & 17.7 & -1.0 & 0.9 \\
\hline Private sector credit (percent change, 12-month basis) & 4.1 & 6.8 & 9.2 & 12.5 \\
\hline U.S. treasury bill rate (percent per annum) & 1.0 & 1.4 & 3.2 & 4.9 \\
\hline Treasury bill rate (percent per annum) $1 /$ & 6.0 & 6.0 & 6.0 & 6.5 \\
\hline \multicolumn{5}{|l|}{ External sector indicators } \\
\hline Exchange rate (per US\$, end of period) & 2.7 & 2.7 & 2.7 & 2.7 \\
\hline REER appreciation (percent change on 12-month basis, end of period) & -5.2 & -3.5 & 5.6 & -4.6 \\
\hline Exports of goods (percent change, 12-month basis) & 10.0 & -18.9 & -5.5 & -15.6 \\
\hline Imports of goods (percent change, 12-month basis) & 25.1 & 3.9 & 20.0 & -8.0 \\
\hline Travel receipts (gross, percent change, 12-month basis) & 16.5 & -19.0 & -5.3 & 29.9 \\
\hline Current account balance (percent of GDP) & -32.2 & -12.4 & -24.9 & -23.9 \\
\hline Capital and financial account balance (percent of GDP) & 29.1 & 19.8 & 22.8 & 33.9 \\
\hline FDI inflows (percent of GDP) & 20.3 & 12.8 & 9.8 & 10.0 \\
\hline Gross international reserves of the ECCB (in US\$ millions) & 539.9 & 632.4 & 600.8 & 696.0 \\
\hline Gross international reserves in months of current year imports in ECCU countries & 4.4 & 4.7 & 4.0 & 4.4 \\
\hline Gross international reserves to broad money in ECCU countries (percent) & 19.8 & 20.5 & 17.9 & 19.7 \\
\hline \multicolumn{5}{|l|}{ Private external debt (percent of GDP) } \\
\hline Public gross external debt (in US\$ million) & 355.8 & 415.6 & 437.0 & 457.2 \\
\hline Public gross external debt to exports of goods and services (percent) & 198.2 & 213.5 & 255.8 & 269.8 \\
\hline Public gross external interest payments to exports of goods and services (percent) & 12.7 & 13.9 & 5.6 & 7.2 \\
\hline Public gross external amortization payments to exports of goods and services (percent) & 5.9 & 9.5 & 5.3 & 6.3 \\
\hline Public gross external interest payments to fiscal revenue (percent) & 18.7 & 26.7 & 9.3 & 10.7 \\
\hline Public gross external amortization payments to fiscal revenue (percent) & 8.6 & 16.6 & 6.7 & 7.6 \\
\hline Gross external financing requirement (in percent of GDP) 2/ & 35.2 & 18.5 & 26.7 & 26.0 \\
\hline \multicolumn{5}{|l|}{ (In percent of GDP) } \\
\hline \multicolumn{5}{|l|}{ Public sector indicators } \\
\hline Central government overall balance (after grants) & -4.8 & -2.8 & 0.5 & -6.8 \\
\hline Public and publicly-guaranteed gross external debt & 79.9 & 96.0 & 86.0 & 87.1 \\
\hline
\end{tabular}

Sources: Ministry of Finance; Eastern Caribbean Central Bank; and Fund staff estimates and projections.

$1 /$ Rate on one-year treasury bills.

2/ Defined as external current account deficit plus external amortization. 
Table 7. Grenada: Millennium Development Goals, 1990-2005

$1990 \quad 1994 \quad 1997 \quad 2000 \quad 2005$

\section{Goal 1. Eradicate extreme poverty and hunger}

Population below $\$ 1$ a day (percent)

Poverty gap at $\$ 1$ a day (percent)

Percentage share of income or consumption held by poorest 20 percent

Prevalence of child malnutrition (percent of children under 5)

Population below minimum level of dietary energy consumption (percent)

Goal 2. Achieve universal primary education

Net primary enrollment ratio (percent of relevant age group)

Primary completion rate, total (percent of relevant age group)

Percentage of cohort reaching grade 5 (percent)

Youth literacy rate (percent ages 15-24)

\section{Goal 3. Promote gender equality}

Ratio of girls to boys in primary and secondary education (percent) Ratio of young literate females to males (percent ages 15-24)

Share of women employed in the nonagricultural sector (percent)

Proportion of seats held by women in national parliament (percent)

\section{Goal 4. Reduce child mortality}

Immunization, measles (percent of children under 12 months)

Infant mortality rate (per 1,000 live births)

Under 5 mortality rate (per 1,000$)$

$\begin{array}{rrrrrr}\ldots & \ldots & \ldots & 85.8 & 83.9 & 1 / \\ \ldots & \ldots & \ldots & 73.7 & 90.2 & 2 / \\ \ldots & \ldots & \ldots & 79.0 & \ldots & 3 / \\ \ldots & \ldots & \ldots & \ldots & \ldots & \end{array}$

\section{Goal 5. Improve maternal health}

Maternal mortality ratio (modeled estimate, per 100,000 live births) Births attended by skilled health staff (percent of total)

\section{Goal 6. Combat HIVIAIDS, malaria and other diseases}

Prevalence of HIV, total (percent ages 15-49)

Contraceptive prevalence rate (percent of women ages 15-49)

Number of children orphaned by HIVIAIDS

\section{Goal 7. Ensure environmental sustainability}

Forest area (percent of total land area)

Nationally protected areas (percent of total land area)

GDP per unit of energy use (PPP \$ per kg oil equivalent)

$\mathrm{CO} 2$ emissions (metric tons per capita)

Access to an improved water source (percent of population)

Access to improved sanitation (percent of population)

Access to secure tenure (percent of population)

\section{Goal 8. Develop a global partnership for development}

Youth unemployment rate (percent of total labor force ages 15-24)

Fixed line and mobile telephones (per 1,000 people) 3/

Internet users (per 1,000 people)

Personal computers (per 1,000 people)

$\begin{array}{rrrrrr}12.0 & \ldots & \ldots & 12.0 & 12.0 & \\ \ldots & \ldots & \ldots & \ldots & \ldots & \\ \ldots & \ldots & \ldots & \ldots & \ldots & \\ 1.2 & 1.7 & 2.1 & 2.0 & 2.2 & 3 / \\ 97.0 & \ldots & \ldots & \ldots & 95.0 & 1 / \\ 97.0 & \ldots & \ldots & \ldots & 96.0 & 1 / \\ \ldots & \ldots & \ldots & \ldots & \ldots & \end{array}$

Source: World Development Indicators database.

1/ Data as of 2004. 


\section{ANNEX-SUMMARY OF APPENDICES}

The full appendices to this report are issued as a supplement and can be viewed in CyberDocs on the Fund's intranet and on the secure extranet for Executive Directors and member officials.

\section{Fund Relations}

Grenada's outstanding purchases amount to SDR 5.2 million, 44.59 percent of quota. Grenada is a member of the ECCB, which manages monetary policy and the exchange system for its eight members. The common currency, the Eastern Caribbean dollar, has been pegged to the U.S. dollar at the rate of EC $\$ 2.70$ per U.S. dollar since July 1976. Grenada has accepted the obligations of Article VIII, Sections 2, 3, and 4, and maintains an exchange system free of restrictions on the making of payments and transfers for current international transactions. The last Article IV consultation was concluded by the Executive Board on July 13, 2005 (IMF Country Report No. 05/290). CARTAC, MCM, and FAD have provided extensive technical assistance.

\section{Relations with the World Bank Group ${ }^{17}$}

In September 2005, the Eastern Caribbean Sub-Region Country Assistance Strategy (CAS) for FY 2006-09 was presented to the Board of the World Bank. The strategy supports the sub-region's development agenda through two main pillars: (1) stimulating growth and improving competitiveness; and (2) reducing vulnerability, by promoting greater social inclusion and strengthening disaster risk management. There are six active World Bank projects in Grenada for a net commitment of approximately US\$42.35 million: Telecommunications and ICT Development, Public Sector Modernization, Education Reform Project, HIV/AIDS Prevention and Control, the Hurricane Ivan Emergency Project, and the Caribbean Catastrophe Risk Insurance Facility.

\section{Relations with the Caribbean Development Bank ${ }^{18}$}

Grenada continued to receive special financing from the Caribbean Development Bank (CDB) for projects intended to facilitate the recovery and reconstruction process; to build capacity; and to assist with poverty reduction. The financing apportioned to Grenada incorporates a blend of the Bank's Special Development Funds (SDF) and ordinary capital resources, designed to yield a concessionary grant element of 35 percent. The main activities include the Grenville Market Square Development Project, Project Management Training, a Country Poverty Assessment, and physical infrastructure and housing.

\section{Statistical Issues}

Grenada participates in the Fund's General Data Dissemination System (GDDS). Although data provision is sufficient for program monitoring, significant improvement is needed to facilitate effective surveillance by addressing weakness in coverage, timeliness and frequency of data.

17 Adapted from text prepared by the World Bank staff in May 2007.

${ }^{18}$ Adapted from text prepared by the Caribbean Development Bank staff in May 2007. 


\title{
INTERNATIONAL MONETARY FUND
}

\author{
GRENADA
}

\section{Debt Sustainability Analysis}

Prepared by the Staff of the International Monetary Fund

In consultation with the World Bank Staff

September 10, 2007

Grenada's debt sustainability outlook has deteriorated since the last debt sustainability analysis (DSA), ${ }^{1}$ with fiscal slippages in 2006-07 a major contributor. Based on Grenada's 2004-06 average Country Policy and Institutional Assessment (CPIA) ${ }^{2}$ rating of "medium," Grenada exceeds the thresholds for the ratio of the net present value (NPV) of external debt to GDP and to exports (but not other thresholds). Even under an active fiscal adjustment scenario (as outlined in the accompanying staff report), the ratio of the NPV of external debt to GDP will remain above the threshold until 2018, and the authorities' target of 60 percent for the ratio of nominal public debt to GDP could only be achieved by 2017. Thus, Grenada is at high risk of debt distress.

\section{Context}

\section{Grenada's economy has rebounded strongly following Hurricanes Ivan and}

Emily. Reconstruction is now largely completed, and the economic outlook is favorable, as several major tourism investment projects get underway. Real GDP growth averaged 7 percent a year during 2005-06 and is projected at 3 percent in 2007 and 4 percent thereafter, reflecting a further strengthening of tourism and the recent initiation of several major tourism projects. Twelve-month CPI inflation, after peaking at almost 6 percent at end2005 following a large adjustment to domestic fuel prices, fell to 2.5 percent in May 2007.

\section{In the aftermath of the hurricanes, the Grenadian authorities recognized that their public sector debt was unsustainable and undertook a collaborative debt restructuring.}

\footnotetext{
$>\quad$ A highly successful exchange for commercial debt was concluded in November 2005. Overall participation reached 91 percent of eligible debt, or about US\$237 million (about 40 percent of total public debt). The restructuring involved a

${ }^{1}$ See Grenada-Request for Three-Year Arrangement Under the Poverty Reduction and Growth Facility (IMF Country Report No. 06/277), Annex I, Medium-Term Outlook and Debt Sustainability.

2 The World Bank's CPIA rates countries against a set of 16 criteria grouped in four clusters: (i) economic management; (ii) structural policies; (iii) policies for social inclusion and equity; and (iv) public sector management and institutions.
} 
reduction of 40-45 percent in net present value terms, for exit yields in the 9-10 percent range, and reduced debt servicing costs by 83 percent during 2005-08.

For official debt, a Paris Club agreement was reached in May 2006. ${ }^{3}$ This reduces debt service to Paris Club creditors by more than 90 percent through 2008. For nonParis Club creditors, agreement has not yet been reached with the Taiwan Province of China, Grenada's largest bilateral creditor (with a quarter of all official bilateral debt).

\section{UNDERLYING DSA ASSUMPTIONS}

3. The baseline scenario is based upon the government's current fiscal policies. The main assumptions of the DSA are described in Box 1.

\section{Box 1. Baseline Macroeconomic Assumptions (2007-27)}

- Real GDP growth after 2007 is projected at 4 percent per year, slightly above the historical average of 3.6 percent and consistent with the previous DSA. In the near term, this growth projection appears realistic given the recent sharp increase in investor interest; the strong growth in Grenada's largest private employer, St. George's University; and the gradual recovery of the agricultural sector. In the longer run, the projection assumes that the authorities undertake the structural reforms needed to sustain growth.

- Inflation is projected to remain low, at 2 percent per year, consistent with historical averages.

- The primary balance of the central government improves from the historical deficit of 2.2 percent to a surplus of about 2 percent, reflecting the authorities' commitment to limit capital expenditure to 8 percent of GDP.

- Grants decline from high post-hurricane levels to 1 percent of GDP, and the interest rate on new borrowing increases from 2 percent through 2010 to 7 percent by 2020, as concessional financing tapers off; with a discount rate of 5 percent this implies a negative grant element for new borrowing in later years. The projection assumes that Grenada receives concessional financing under the PetroCaribe initiative during 2007-11 (see below), and that the grant element is used to finance budgeted programs, replacing more expensive forms of budget financing. The interest rate on debt restructured in 2005 increases from 1 percent through 2008 to 9 percent by 2019 .

- The current account deficit is assumed to narrow over time due to strong growth in tourism and a falloff in imports from high post-hurricane levels; the deficit is increasingly financed by foreign investment.

\footnotetext{
${ }^{3}$ Under Paris Club rules, the rescheduling could be suspended if the first review under the PRGF is not completed.
} 


\section{Evaluation of Public Sector Debt Sustainability}

\section{Grenada's public debt as of end-2006}

\section{As of end-2006, Grenada's public sector debt stood at 125 percent of GDP.}

External debt accounted for 69 percent of total debt (Table 1), almost all owed by the central government. Commercial debt accounted for about one-half of external debt, and multilateral debt, mostly from the Caribbean Development Bank, accounted for another one-third, with the remainder owed to bilateral and non-Paris Club creditors. In NPV terms, public sector debt stood at 114 percent of GDP, reflecting the concessional element of multilateral and restructured debt. As noted above, the restructuring of Grenada's commercial debt implied a reduction of 40-45 percent on the NPV of future debt servicing flows. As with the previous DSA, this calculation assumes that the bilateral debt to non-Paris Club creditors is restructured on terms comparable to those of the commercial debt exchange.

\section{The baseline (current policies) scenario}

5. Grenada's debt sustainability outlook has deteriorated since the last DSA, in large part due to fiscal slippages in 2006-07. ${ }^{4}$ Public sector debt increased by 5 percentage points of GDP during 2006 to 125 percent of GDP (Table A1a), rather than falling as anticipated in the previous DSA. The authorities' nominal debt target of 60 percent of GDP will now be achieved by 2025 under the baseline (current policies) projection rather than in 2015 in the previous DSA. The NPV of debt falls to 57 percent of GDP by 2027 (Figure 1), slightly higher than the nominal debt ratio, reflecting commercial debt at interest rates above the discount rate of 5 percent. The public sector debt-to-revenue ratio falls from 301 percent in 2006 to 139 percent in 2027. By contrast, the debt service-to-revenue ratio would increase from 9.9 percent in 2006 to 11.5 percent in 2027, reflecting declining concessionality, with a ratio of 21-24 percent during 2021-25 as restructured debt amortizes. ${ }^{5}$

\section{The baseline projection incorporates debt accumulated under the PetroCaribe} Agreement during 2007-11. Based on current oil prices, this agreement would provide concessional financing of about 0.3 percent of GDP in 2007, increasing to an annual average of about 1.4 percent of GDP. ${ }^{6}$ The financing terms are highly concessional, with an interest

\footnotetext{
${ }^{4}$ Some key underlying assumptions have also changed, contributing to the deterioration in the debt sustainability outlook. The previous DSA included only half of guaranteed debt and assumed a discount rate of 9 percent. Consistent with the Debt Sustainability Framework for Low-Income Countries, the current DSA includes all guaranteed debt and assumes a discount rate of 5 percent.

5 The high level of debt service in 2007 incorporates the clearance of domestic expenditure arrears, which were 2.8 percent of GDP at end-2006.

${ }^{6}$ The PetroCaribe Agreement finances 40 percent of oil imports (up to a ceiling) when the international price of oil is between US\$50 and US\$90 per barrel. The share financed would be lower than 40 percent if the oil price falls below US $\$ 50$ per barrel and would be higher if it rises to US\$100 or more per barrel.
} 
rate of 1 percent and a maturity of 25 years (including a two-year grace period), implying a grant element of 48 percent if the liability is in U.S. dollars.

7. Recently missed payments on domestic debt signal financial distress. In April 2007, Standard and Poor's downgraded Grenada's credit rating from B- to CCC+, citing rising fiscal pressures and lack of payments discipline, including arrears (since cleared) to domestic commercial banks. The downgrade was reversed in August 2007 owing to "measures taken in June 2007 to streamline the government's debt-payment mechanism." In addition, Grenada could not meet its payment obligations on EC $\$ 20.3$ million of unrestructured domestic debt to the nonbank public due on June $30{ }^{7}$

\section{Alternative scenarios and stress tests}

\section{Active fiscal policy scenario}

\section{Under an active fiscal adjustment scenario, the authorities' nominal debt target of 60 percent of GDP would be achieved by 2017 (Table A1b). This} represents a delay of three years relative to the previous target date. Under the active scenario, the NPV of debt falls to 37 percent of GDP by 2027. This scenario assumes that all divestment proceeds would be used to pay down more expensive debt, rather than to finance additional budgetary expenditures. Capital expenditure would be limited to just under 9 percent of GDP in 2007 and to 8 percent per year thereafter. Other

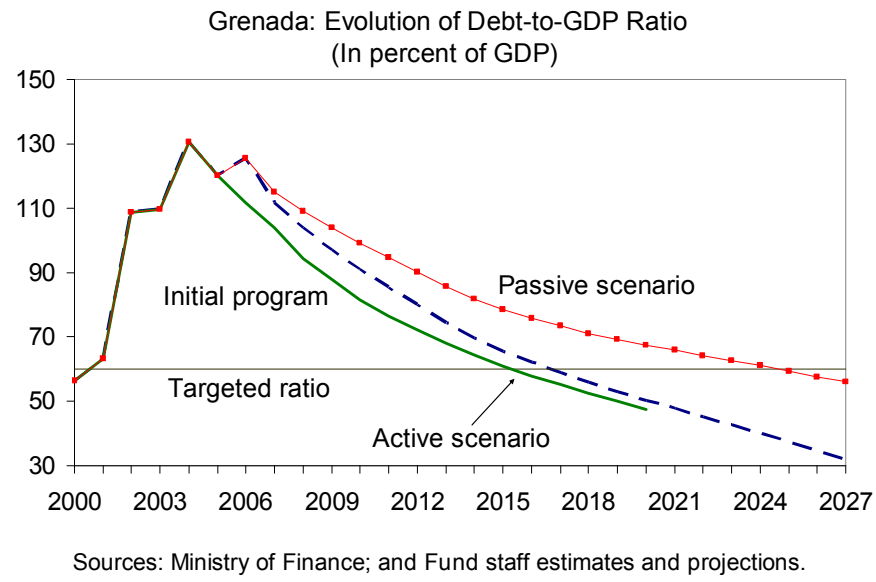
assumptions include: implementing some additional revenue-enhancing measures over the medium term (e.g., an inflation adjustment to the fuel surcharge), and keeping real wages and spending on transfers, goods, and services constant over the medium term. This scenario also assumes that the first review under the PRGF is completed by year-end and the positive assessment by the Fund unlocks some additional grants conditioned on such an assessment.

\footnotetext{
${ }^{7}$ The authorities informed the bond holders that full payment would be made by the fourth quarter of 2007.
} 
Grenada: Key Assumptions and Indicators in the DSA

(In percent of GDP, unless otherwise indicated)

\begin{tabular}{lrrrrrrr}
\hline Baseline Scenario & $\mathbf{2 0 0 7}$ & $\mathbf{2 0 0 8}$ & $\mathbf{2 0 0 9}$ & $\mathbf{2 0 1 0}$ & $\mathbf{2 0 1 5}$ & $\mathbf{2 0 2 0}$ & $\mathbf{2 0 2 5}$ \\
\hline Total revenues and grants & 43.1 & 43.7 & 43.1 & 42.9 & 41.5 & 41.3 & 41.2 \\
Total expenditure & 46.3 & 44.4 & 43.8 & 43.3 & 43.1 & 43.8 & 43.1 \\
Primary balance & -0.7 & 1.9 & 2.0 & 2.1 & 1.7 & 1.8 & 1.7 \\
Overall balance & -3.2 & -0.6 & -0.7 & -0.4 & -1.6 & -2.4 & -1.9 \\
Public debt & 115.1 & 109.0 & 104.0 & 99.3 & 78.3 & 67.4 & 59.3 \\
GDP growth rate 1/ & 3.0 & 4.0 & 4.0 & 4.0 & 4.0 & 4.0 & 4.0 \\
Inflation rate (average) & 2.4 & 2.0 & 2.0 & 2.0 & 2.0 & 2.0 & 2.0 \\
\hline
\end{tabular}

\begin{tabular}{lrrrrrrr}
\hline Active Scenario & $\mathbf{2 0 0 7}$ & $\mathbf{2 0 0 8}$ & $\mathbf{2 0 0 9}$ & $\mathbf{2 0 1 0}$ & $\mathbf{2 0 1 5}$ & $\mathbf{2 0 2 0}$ & $\mathbf{2 0 2 5}$ \\
\hline Total revenues and grants & 44.3 & 44.4 & 43.8 & 43.0 & 41.8 & 41.6 & 41.4 \\
Total expenditure & 43.0 & 43.2 & 42.4 & 41.9 & 41.8 & 42.1 & 41.1 \\
Primary balance & 3.8 & 3.7 & 4.0 & 3.5 & 2.8 & 2.6 & 2.5 \\
Overall balance & 1.3 & 1.2 & 1.4 & 1.2 & 0.1 & -0.5 & 0.3 \\
Public debt & 111.6 & 103.9 & 97.1 & 91.0 & 65.4 & 50.2 & 37.2 \\
GDP growth rate 1/ & 3.0 & 4.0 & 4.0 & 4.0 & 4.0 & 4.0 & 4.0 \\
Inflation rate (average) & 2.4 & 2.0 & 2.0 & 2.0 & 2.0 & 2.0 & 2.0 \\
\hline
\end{tabular}

Sources: Ministry of Finance; and Fund staff estimates and projections.

$1 /$ Both scenarios assume an active structural reform program.

\section{Other scenarios}

\section{Economic growth and the primary balance are key factors underpinning}

Grenada's debt trajectory. In a scenario under which historical levels of the primary deficit (2.5 percent of GDP) and GDP growth (3.7 percent) remain unchanged, the NPV of debt would rise to 130 percent by 2027 (Table A1b). The NPV of debt to revenue increases over time, and the debt service-to-revenue ratio increases to 33 percent (Scenario A2).

10. The need to contain expenditure if growth does not materialize is underscored by the sensitivity analysis. In Bound Test B1, growth falls to -2.2 percent in 2008 and 2009, fiscal revenue is assumed to remain constant as a share of GDP, while expenditure is held constant in nominal terms. In this scenario, the ratio of the NPV of debt to GDP rises sharply to 157 percent.

\section{Further exogenous shocks would also have a significant impact on Grenada's}

debt dynamics. Both growth and the primary balance are adversely impacted by shocks, including natural disasters, foreign growth, and the volatility of grants. For example, with a natural disaster in 2008 that reduced GDP growth to zero for three years and increased the primary deficit by 3 percentage points of GDP for each of those years, the NPV of debt would rise to 71 percent of GDP (Scenario A5). Grenada's participation in the World Bank's Caribbean Catastrophe Insurance Facility, which is not incorporated in this analysis, would help cushion the financial impact of further disasters. 


\section{Evaluation of EXternal Debt Sustainability}

12. Grenada exceeds its thresholds — based on the Debt Sustainability Framework for Low-Income Countries - for the ratio of the NPV of external debt to GDP and to exports. Based on Grenada's 2004-06 average CPIA rating of "medium," the thresholds are 40 percent and 150 percent for the ratios to GDP and exports respectively, while for 2006, Grenada's ratios were 75 percent and 234 percent respectively. ${ }^{9}$ It falls below thresholds on the NPV of debt to revenue and for the ratio of debt service to exports and to revenue.

13. Although Grenada's external public debt would fall significantly in the baseline scenario, it would remain above the NPV of debt-to-GDP threshold for an extended period (Table A2a). The ratio of the NPV of external public debt to GDP would not fall below the 40 percent threshold before 2022, while the NPV of debt to exports would only fall below the 150 percent threshold by 2011 (Figure 2).

14. Bound tests show significant sensitivity in the short term, with much weaker effects by 2027 (Table A2b). Under an alternative scenario with key variables - GDP growth, the current account deficit, and FDI) at historical averages - the NPV of debt would rise to 156 percent of GDP by 2027 (Scenario A2). Under this scenario, the debt-to-exports ratio would rise to 347 percent in the same year, while the debt service-to-exports ratio would rise sharply as restructured debt matures.

\section{Conclusions}

15. Owing in large part to fiscal slippages in 2006-07, Grenada's debt sustainability has deteriorated since the previous DSA. The analysis indicates that Grenada's debt is unsustainable under current fiscal policies, even though they incorporate some adjustment. While the authorities' efforts to limit expenditure in 2007 below the budgeted level is a first step toward a sustainable debt trajectory, much greater fiscal adjustment will be needed to ensure that debt is placed firmly on a declining trajectory. The recently missed payment on domestic debt and Standard and Poor's downgrade (albeit subsequently reversed) underscore the financial strains and the need for urgent corrective action.

16. On the external front, Grenada is at high risk of debt distress, with several debt indicators above their indicative thresholds under a variety of scenarios. Even under an active fiscal adjustment scenario, it will require a determined and prolonged effort to bring debt down to sustainable levels. Furthermore, this favorable outcome would be severely affected by another external shock, such as a hurricane or a shock to tourism, leading to an unsustainable trajectory for debt.

\footnotetext{
${ }^{8}$ The previous three-year average (2003-05) CPIA rating for Grenada's performance was "strong." Even with this higher rating, Grenada would still exceed the indicative thresholds for the debt ratios to GDP and exports.

${ }^{9}$ See Public Information Notice (PIN) No. 05/59 (May 4, 2005).
} 
Table 1. Grenada: Public Sector Debt, 2006

(Year end, in millions of U.S. dollars)

\begin{tabular}{|c|c|c|c|}
\hline & \multirow[b]{2}{*}{ Stock } & \multicolumn{2}{|c|}{ Percent of } \\
\hline & & Total Debt & GDP \\
\hline Public sector debt $1 /$ & 658.4 & 100.0 & 125.4 \\
\hline Central government debt & 576.8 & 87.6 & 109.9 \\
\hline Central government guaranteed debt & 61.1 & 9.3 & 11.7 \\
\hline Other public sector debt & 20.5 & 3.1 & 3.9 \\
\hline External debt & 457.2 & 69.4 & 87.1 \\
\hline A. Central government & 413.3 & 62.8 & 78.7 \\
\hline 1. Multilateral & 136.0 & 20.7 & 25.9 \\
\hline CDB & 84.2 & 12.8 & 16.0 \\
\hline IDA & 27.9 & 4.2 & 5.3 \\
\hline IBRD & 9.0 & 1.4 & 1.7 \\
\hline IMF & 9.5 & 1.4 & 1.8 \\
\hline Other multilateral & 5.4 & 0.8 & 1.0 \\
\hline 2. Official bilateral & 77.9 & 11.8 & 14.8 \\
\hline Paris Club 2/ & 16.4 & 2.5 & 3.1 \\
\hline Belgium & 6.7 & 1.0 & 1.3 \\
\hline France & 4.2 & 0.6 & 0.8 \\
\hline Russian Federation & 0.2 & 0.0 & 0.0 \\
\hline United Kingdom & 2.5 & 0.4 & 0.5 \\
\hline United States & 2.8 & 0.4 & 0.5 \\
\hline Non-Paris Club & 61.5 & 9.3 & 11.7 \\
\hline Taiwan Province of China & 20.3 & 3.1 & 3.9 \\
\hline Kuwait & 18.5 & 2.8 & 3.5 \\
\hline Trinidad and Tobago & 17.0 & 2.6 & 3.2 \\
\hline Other bilateral & 5.8 & 0.9 & 1.1 \\
\hline 3. Commercial, total & 199.4 & 30.3 & 38.0 \\
\hline Restructured bonds & 193.5 & 29.4 & 36.9 \\
\hline Unrestructured bonds & 5.8 & 0.9 & 1.1 \\
\hline $\begin{array}{l}\text { B. Central government guaranteed } \\
\text { Of which }\end{array}$ & 23.5 & 3.6 & 4.5 \\
\hline Paris Club & 7.8 & 1.2 & 1.5 \\
\hline C. Other public sector & 20.5 & 3.1 & 3.9 \\
\hline Domestic debt & 201.2 & 30.6 & 38.3 \\
\hline A. Central government & 163.5 & 24.8 & 31.2 \\
\hline Restructured Bonds & 68.1 & 10.3 & 13.0 \\
\hline Unrestructured bonds & 11.0 & 1.7 & 2.1 \\
\hline Treasury bills & 26.5 & 4.0 & 5.0 \\
\hline Commercial bank loans & 24.2 & 3.7 & 4.6 \\
\hline Overdraft & 18.4 & 2.8 & 3.5 \\
\hline Domestic arrears & 14.8 & 2.3 & 2.8 \\
\hline Compensation claims & 0.6 & 0.1 & 0.1 \\
\hline B. Central government guaranteed & 37.7 & 5.7 & 7.2 \\
\hline \multicolumn{4}{|l|}{ Memorandum item: } \\
\hline Nominal GDP & 524.9 & & \\
\hline
\end{tabular}

Sources: Grenada authorities; and Fund staff estimates.

$1 /$ Includes central government liabilities to the National Insurance Scheme. 
Table A1a. Grenada: Public Sector Debt Sustainability Framework, 2004-07

(In percent of GDP, unless otherwise indicated)

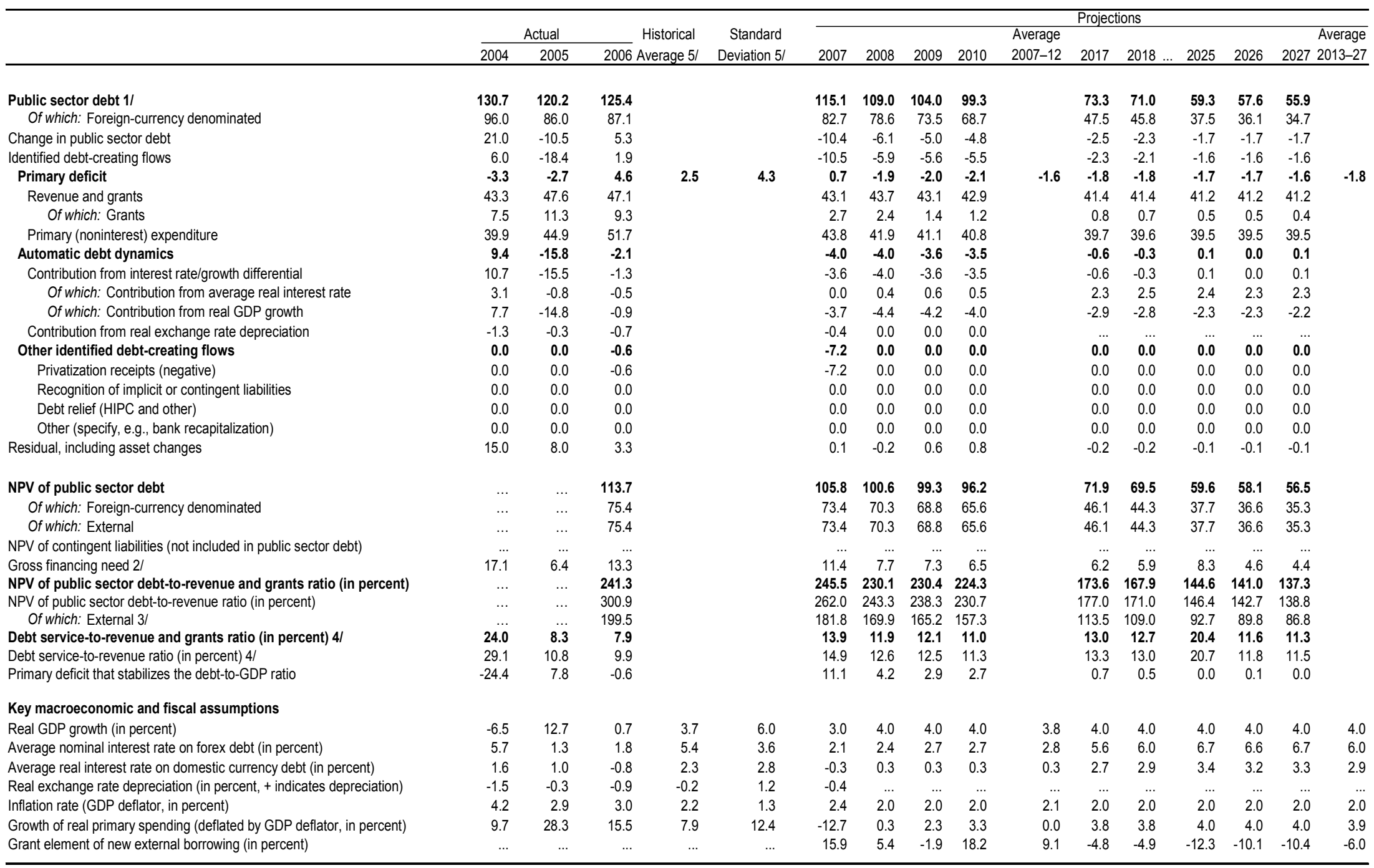

Sources: Country authorities; and Fund staff estimates and projections.

$1 /$ The coverage of public sector debt is public and publicly guaranteed debt, including debt of public enterprises and the debt of the central government to the NIS.

2/ Gross financing need is defined as the primary deficit plus debt service plus the stock of short-term debt at the end of the last period.

$3 /$ Revenues excluding grants.

4/ Debt service is defined as the sum of interest and amortization of medium and long-term debt

5/ Historical averages and standard deviations are generally derived over the past 10 years, subject to data availability. 
Table A1b. Grenada: Sensitivity Analysis for Key Indicators of Public Sector Debt 2007-27

NPV of Debt-to-GDP Ratio
Baseline
A. Alternative Scenarios
A1. Active policy scenario
A2. Real GDP growth and primary balance are at historical averages
A3. Primary balance is unchanged from 2007
A4. Permanently lower GDP growth $1 /$
A5. Natural disasters in 2008
B. Bound Tests
B1. Real GDP growth is at historical average minus one standard deviations in 2008-09
B2. Primary balance is at historical average minus one standard deviations in 2008-09
B3. Combination of B1-B2 using one half standard deviation shocks
B4. One-time 30 percent real depreciation in 2008
B5. 10 percent of GDP increase in other debt-creating flows in 2008

NPV of Debt-to-Revenue Ratio 2/

Baseline

\section{A. Alternative scenarios}

A1. Active policy scenario

A2. Real GDP growth and primary balance are at historical averages

A3. Primary balance is unchanged from 2007

A4. Permanently lower GDP growth $1 /$

A5. Natural disasters in 2008

\section{B. Bound Tests}

B1. Real GDP growth is at historical average minus one standard deviations in 2008-09

B2. Primary balance is at historical average minus one standard deviations in 2008-09

B3. Combination of B1-B2 using one half standard deviation shocks

B4. One-time 30 percent real depreciation in 2008

B5. 10 percent of GDP increase in other debt-creating flows in 2008
Projections

\begin{tabular}{llllllll}
\hline 2007 & 2008 & 2009 & 2010 & 2011 & 2012 & 2017 & 2027 \\
\hline
\end{tabular}

$\begin{array}{rrrrrrrr}106 & 101 & 99 & 96 & 93 & 89 & 72 & 57 \\ & & & & & & & \\ 104 & 99 & 95 & 92 & 88 & 83 & 64 & 37 \\ 106 & 105 & 108 & 109 & 110 & 110 & 113 & 130 \\ 106 & 103 & 104 & 104 & 103 & 101 & 95 & 97 \\ 106 & 103 & 104 & 104 & 104 & 104 & 114 & 192 \\ 106 & 108 & 113 & 117 & 112 & 107 & 88 & 71\end{array}$

\section{Debt Service-to-Revenue Ratio 2/}

\section{Baseline}

$\begin{array}{rrrrrrrr}106 & 110 & 121 & 123 & 124 & 125 & 131 & 157 \\ 106 & 108 & 115 & 112 & 109 & 105 & 89 & 74 \\ 106 & 110 & 118 & 115 & 111 & 107 & 91 & 76 \\ 106 & 132 & 131 & 128 & 124 & 120 & 103 & 91 \\ 106 & 110 & 108 & 105 & 101 & 97 & 80 & 64\end{array}$

$\begin{array}{llllllll}245 & 230 & 230 & 224 & 217 & 209 & 174 & 137\end{array}$

$\begin{array}{lllllllr}235 & 223 & 218 & 213 & 205 & 196 & 154 & 91 \\ 246 & 240 & 251 & 255 & 257 & 260 & 272 & 316 \\ 246 & 236 & 242 & 242 & 241 & 239 & 230 & 237 \\ 245 & 234 & 241 & 242 & 243 & 244 & 274 & 464 \\ 246 & 245 & 262 & 271 & 262 & 252 & 211 & 171\end{array}$

\section{A. Alternative Scenarios}

A1. Active policy scenario

A2. Real GDP growth and primary balance are at historical averages

A3. Primary balance is unchanged from 2007

A4. Permanently lower GDP growth $1 /$

A5. Natural disasters in 2008

$\begin{array}{llllllll}245 & 250 & 279 & 286 & 290 & 294 & 316 & 382 \\ 245 & 248 & 267 & 261 & 254 & 247 & 214 & 180 \\ 245 & 250 & 273 & 267 & 260 & 253 & 219 & 185 \\ 245 & 301 & 304 & 298 & 291 & 283 & 248 & 220 \\ 246 & 251 & 251 & 245 & 237 & 229 & 193 & 154\end{array}$

\section{B. Bound Tests}

B1. Real GDP growth is at historical average minus one standard deviations in 2008-09 B2. Primary balance is at historical average minus one standard deviations in 2008-09

B3. Combination of B1-B2 using one half standard deviation shocks

B4. One-time 30 percent real depreciation in 2008

B5. 10 percent of GDP increase in other debt-creating flows in 2008

Sources: Country authorities; and Fund staff estimates and projections.

$1 /$ Assumes that real GDP growth is at baseline minus one standard deviation divided by the square root of 20 (i.e., the length of the projection period).

2/ Revenues are defined inclusive of grants. 
Table A2a. Grenada: External Debt Sustainability Framework, 2004-27 1/

(In percent of GDP, unless otherwise indicated)

\begin{tabular}{|c|c|c|c|c|c|c|c|c|c|c|c|c|c|c|c|c|}
\hline & \multirow{2}{*}{\multicolumn{3}{|c|}{ Actual }} & \multirow{3}{*}{$\begin{array}{r}\text { Historical } \\
\text { Average 6/ } \\
\end{array}$} & \multirow{3}{*}{$\begin{array}{c}\text { Standard } \\
\text { Deviation 6/ }\end{array}$} & \multicolumn{11}{|c|}{ Projections } \\
\hline & & & & & & \multirow[b]{2}{*}{2007} & \multirow[b]{2}{*}{2008} & \multirow[b]{2}{*}{2009} & \multirow[b]{2}{*}{2010} & \multirow{2}{*}{$\begin{array}{l}\text { Average } \\
2007-12 \\
\end{array}$} & \multirow[b]{2}{*}{2017} & \multirow[b]{2}{*}{$2018 \ldots$} & \multirow[b]{2}{*}{2025} & \multirow[b]{2}{*}{2026} & \multirow[b]{2}{*}{2027} & \multirow{2}{*}{$\begin{array}{l}\text { Average } \\
2013-27 \\
\end{array}$} \\
\hline & 2004 & 2005 & 2006 & & & & & & & & & & & & & \\
\hline External debt (nominal) $1 /$ & 96.0 & 86.0 & 87.1 & & & 82.7 & 78.6 & 73.5 & 68.7 & & 47.5 & 45.8 & 37.5 & 36.1 & 34.7 & \\
\hline Change in external debt & 16.1 & -10.0 & 1.1 & & & -4.4 & -4.0 & -5.1 & -4.9 & & -1.8 & -1.6 & -1.3 & -1.4 & -1.4 & \\
\hline Identified net debt-creating flows & 2.2 & 1.1 & 11.5 & & & 7.2 & 6.7 & 4.1 & 1.9 & & 3.2 & 3.3 & 3.1 & 3.0 & 2.9 & \\
\hline Noninterest current account deficit & 6.1 & 23.0 & 21.6 & 20.2 & 7.0 & 22.4 & 22.4 & 19.2 & 16.9 & & 16.6 & 16.5 & 16.2 & 16.1 & 16.2 & 16.4 \\
\hline Deficit in balance of goods and services & 30.3 & 43.0 & 36.5 & & & 30.9 & 30.3 & 26.7 & 23.9 & & 22.9 & 22.8 & 22.6 & 22.6 & 22.6 & \\
\hline Exports & 45.0 & 33.6 & 32.3 & & & 37.7 & 37.3 & 39.6 & 41.5 & & 43.0 & 43.0 & 43.2 & 43.1 & 43.1 & \\
\hline Imports & 75.3 & 76.6 & 68.8 & & & 68.6 & 67.5 & 66.3 & 65.4 & & 65.9 & 65.8 & 65.8 & 65.7 & 65.7 & \\
\hline Net current transfers (negative = inflow) & -27.9 & -22.4 & -17.4 & -11.9 & 8.5 & -15.5 & -14.7 & -14.3 & -13.7 & & -12.5 & -12.5 & -12.3 & -12.3 & -12.3 & -12.4 \\
\hline Other current account flows (negative $=$ net inflow) & 3.7 & 2.5 & 2.5 & & & 7.0 & 6.9 & 6.7 & 6.6 & & 6.2 & 6.2 & 5.9 & 5.9 & 5.8 & \\
\hline Net FDI (negative $=$ inflow) & -12.5 & -9.6 & -9.7 & -12.9 & 3.3 & -15.2 & -15.1 & -14.9 & -14.7 & & -14.1 & -14.1 & -14.1 & -14.1 & -14.1 & -14.1 \\
\hline Endogenous debt dynamics $2 /$ & 8.5 & -12.3 & -0.4 & & & 0.0 & -0.6 & -0.3 & -0.3 & & 0.7 & 0.9 & 1.0 & 0.9 & 0.9 & \\
\hline Contribution from nominal interest rate & 6.3 & 1.9 & 2.3 & & & 2.5 & 2.5 & 2.7 & 2.5 & & 2.6 & 2.7 & 2.5 & 2.3 & 2.3 & \\
\hline Contribution from real GDP growth & 5.4 & -10.4 & -0.6 & & & -2.5 & -3.1 & -3.0 & -2.8 & & -1.9 & -1.8 & -1.5 & -1.4 & -1.4 & \\
\hline Contribution from price and exchange rate changes & -3.1 & -3.8 & -2.1 & & & -2.2 & -2.4 & -1.8 & -1.5 & & -1.0 & -0.9 & -0.8 & -0.7 & -0.7 & \\
\hline Residual $3 /$ & 13.9 & -11.1 & -10.4 & & & -9.5 & -8.4 & -7.4 & -5.2 & & -4.1 & -4.0 & -3.7 & -3.6 & -3.6 & \\
\hline \multicolumn{17}{|l|}{ Of which } \\
\hline Exceptional financing & 0.0 & 0.0 & -2.5 & & & -0.2 & -0.2 & -0.1 & -0.1 & & 0.0 & 0.0 & 0.0 & 0.0 & 0.0 & \\
\hline NPV of external debt 4/ & $\ldots$ & $\ldots$ & 75.4 & & & 73.4 & 70.3 & 68.8 & 65.6 & & 46.1 & 44.3 & 37.7 & 36.6 & 35.3 & \\
\hline In percent of exports & $\ldots$ & $\ldots$ & 233.5 & & & 194.6 & 188.6 & 174.0 & 158.2 & & 107.3 & 103.0 & 87.4 & 84.8 & 82.0 & \\
\hline NPV of PPG external debt & ... & ... & 75.4 & & & 73.4 & 70.3 & 68.8 & 65.6 & & 46.1 & 44.3 & 37.7 & 36.6 & 35.3 & \\
\hline In percent of exports & $\ldots$ & $\ldots$ & 233.5 & & & 194.6 & 188.6 & 174.0 & 158.2 & & 107.3 & 103.0 & 87.4 & 84.8 & 82.0 & \\
\hline Debt service-to-exports ratio (in percent) & 22.6 & 8.7 & 11.3 & & & 12.2 & 13.5 & 12.5 & 10.6 & & 9.1 & 9.1 & 14.4 & 8.4 & 8.1 & \\
\hline PPG debt service-to-exports ratio (in percent) & 22.6 & 8.7 & 11.3 & & & 12.2 & 13.5 & 12.5 & 10.6 & & 9.1 & 9.1 & 14.4 & 8.4 & 8.1 & \\
\hline Total gross financing need (millions of U.S. dollars) & 16.5 & 83.3 & 81.6 & & & 65.4 & 73.1 & 58.6 & 43.9 & & 65.0 & 68.0 & 135.5 & 97.4 & 100.7 & \\
\hline Noninterest current account deficit that stabilizes debt ratio & -10.0 & 33.0 & 20.5 & & & 26.8 & 26.4 & 24.3 & 21.7 & & 18.4 & 18.1 & 17.5 & 17.5 & 17.5 & \\
\hline \multicolumn{17}{|l|}{ Key macroeconomic assumptions } \\
\hline Real GDP growth (in percent) & -6.5 & 12.7 & 0.7 & 3.3 & 5.7 & 3.0 & 4.0 & 4.0 & 4.0 & 3.8 & 4.0 & 4.0 & 4.0 & 4.0 & 4.0 & 4.0 \\
\hline GDP deflator in U.S. dollar terms (change in percent) & 4.0 & 4.1 & 2.5 & 2.2 & 1.4 & 2.5 & 2.9 & 2.3 & 2.1 & 2.3 & 2.0 & 2.0 & 2.0 & 2.0 & 2.0 & 2.0 \\
\hline Effective interest rate (percent) 5/ & 7.6 & 2.3 & 2.8 & 6.9 & 3.2 & 3.0 & 3.3 & 3.6 & 3.6 & 3.4 & 5.6 & 6.0 & 6.7 & 6.6 & 6.7 & 6.0 \\
\hline Growth of exports of G\&S (U.S. dollar terms, in percent) & 8.5 & -12.3 & -0.8 & 2.6 & 17.0 & 23.4 & 5.8 & 12.9 & 11.2 & 11.4 & 6.2 & 6.2 & 6.1 & 6.0 & 6.0 & 6.2 \\
\hline Growth of imports of G\&S (U.S. dollar terms, in percent) & 5.3 & 19.4 & -7.3 & 5.4 & 11.2 & 5.4 & 5.4 & 4.4 & 4.7 & 5.5 & 5.9 & 6.0 & 6.1 & 6.0 & 6.1 & 6.1 \\
\hline Grant element of new public sector borrowing (in percent) & $\ldots$ & $\ldots$ & $\ldots$ & $\ldots$ & $\ldots$ & 15.9 & 5.4 & -1.9 & 18.2 & 9.1 & -4.8 & -4.9 & -12.3 & -10.1 & -10.4 & -6.0 \\
\hline \multicolumn{17}{|l|}{ Memorandum item: } \\
\hline Nominal GDP (millions of U.S. dollars) & 433.0 & 508.3 & 524.9 & & & 554.3 & 593.5 & 631.4 & 670.1 & & $1,013.0$ & $1,074.6$ & $1,624.31$ & $1,723.1$ & $1,827.8$ & \\
\hline
\end{tabular}

Sources: Grenada authorities; and Fund staff estimates and projections.

$1 /$ Includes public sector gross debt and publicly guaranteed external debt.

2/ Derived as $[r-g-r(1+g)] /(1+g+r+g r)$ times previous period debt ratio, with $r=$ nominal interest rate; $g=$ real GDP growth rate, and $r=$ growth rate of GDP deflator in U.S. dollar terms.

$3 /$ Includes capital grants, migrants transfers, change in commercial bank net foreign assets, exceptional financing (i.e., changes in arrears and debt relief); changes in gross foreign assets; and valuation adjustments.

4/ Assumes that NPV of private sector debt is equivalent to its face value.

6/ Historical averages and standard deviations are generally derived over the past ten years, subject to data availability. 
Table A2b. Grenada: Sensitivity Analyses for Key Indicators of External Public Debt, 2007-27

(In percent)

\begin{tabular}{|c|c|c|c|c|c|c|c|c|}
\hline & \multicolumn{8}{|c|}{ Projections } \\
\hline & 2007 & 2008 & 2009 & 2010 & 2011 & 2012 & 2017 & 2027 \\
\hline \multicolumn{9}{|c|}{ NPV of debt-to-GDP ratio } \\
\hline $\begin{array}{l}\text { Baseline } \\
\text { A. Alternative Scenarios }\end{array}$ & 73 & 70 & 69 & 66 & 62 & 59 & 46 & 35 \\
\hline A1. Active policy scenario & 72 & 69 & 66 & 63 & 60 & 57 & 42 & 20 \\
\hline A2. Key variables at their historical averages in 2007-27 1/ & 73 & 71 & 74 & 76 & 77 & 78 & 84 & 96 \\
\hline A3. New public sector loans on less favorable terms in 2007-27 2/ & 73 & 71 & 70 & 67 & 63 & 60 & 49 & 46 \\
\hline \multicolumn{9}{|l|}{ B. Bound Tests } \\
\hline B1. Real GDP growth at historical average minus one standard deviation in 2007-08 & 73 & 75 & 78 & 74 & 71 & 67 & 52 & 40 \\
\hline B2. Export value growth at historical average minus one standard deviation in 2007-08 3/ & 73 & 78 & 92 & 88 & 83 & 78 & 60 & 39 \\
\hline B3. U.S. dollar GDP deflator at historical average minus one standard deviation in 2007-08 & 73 & 72 & 71 & 68 & 64 & 61 & 48 & 37 \\
\hline B4. Net nondebt creating flows at historical average minus one standard deviation in $2007-08$ & 73 & 88 & 102 & 98 & 93 & 87 & 66 & 41 \\
\hline B5. Combination of B1-B4 using one-half standard deviation shocks & 73 & 86 & 108 & 103 & 98 & 92 & 70 & 44 \\
\hline B6. One-time 30 percent nominal depreciation relative to the baseline in $20075 /$ & 73 & 99 & 97 & 93 & 88 & 83 & 65 & 50 \\
\hline
\end{tabular}

\section{NPV of debt-to-exports ratio}

Baseline

A. Alternative Scenarios

A1. Active policy scenario

A2. Key variables at their historical averages in 2007-27 1/

A3. New public sector loans on less favorable terms in 2007-27 2/

\section{B. Bound Tests}

B1. Real GDP growth at historical average minus one standard deviation in 2007-08

B2. Export value growth at historical average minus one standard deviation in 2007-08 3/

B3. U.S. dollar GDP deflator at historical average minus one standard deviation in 2007-08

B4. Net nondebt creating flows at historical average minus one standard deviation in 2007-08

B5. Combination of B1-B4 using one-half standard deviation shocks

B6. One-time 30 percent nominal depreciation relative to the baseline in 2007 5/

$\begin{array}{rrrrrrrr}195 & 189 & 174 & 158 & 147 & 138 & 107 & 82 \\ & & & & & & & \\ 192 & 186 & 168 & 153 & 142 & 133 & 99 & 47 \\ 195 & 191 & 186 & 183 & 182 & 183 & 195 & 222 \\ 195 & 190 & 176 & 161 & 149 & 142 & 114 & 106\end{array}$

$\begin{array}{rrrrrrrr}195 & 189 & 174 & 158 & 147 & 138 & 107 & 82 \\ 195 & 257 & 377 & 345 & 319 & 300 & \mathbf{2 2 6} & 148 \\ 195 & 189 & 174 & 158 & 147 & 138 & 107 & 82 \\ 195 & 235 & 259 & 237 & 219 & 206 & 153 & 95 \\ 195 & 248 & 335 & 306 & 283 & 266 & 199 & 126 \\ 195 & 189 & 174 & 158 & 147 & 138 & 107 & 82\end{array}$

Debt service ratio

Baseline

A1. Active policy scenario

A2. Key variables at their historical averages in $2007-261 /$

A3. New public sector loans on less favorable terms in 2007-26 $2 /$

\section{B. Bound Tests}

B1. Real GDP growth at historical average minus one standard deviation in 2007-08

B2. Export value growth at historical average minus one standard deviation in 2007-08 3/

B3. U.S. dollar GDP deflator at historical average minus one standard deviation in 2007-08

B4. Net nondebt creating flows at historical average minus one standard deviation in 2007-08

B5. Combination of B1-B4 using one-half standard deviation shocks

B6. One-time 30 percent nominal depreciation relative to the baseline in $20075 /$

Memorandum item:

Grant element assumed on residual financing (i.e., financing required above baseline) $6 /$

$\begin{array}{rrrrrrrr}12 & 13 & 12 & 11 & 10 & 11 & 9 & 8 \\ 22 & 15 & 15 & 13 & 12 & 11 & 9 & 9 \\ 12 & 14 & 13 & 11 & 10 & 13 & 16 & 22 \\ 12 & 13 & 12 & 11 & 10 & 11 & 9 & 10\end{array}$

Source: Fund staff projections and simulations.

1/ Variables include real GDP growth, growth of GDP deflator (in U.S. dollar terms), noninterest current account in percent of GDP, and nondebt creating flows.

2/ Assumes that the interest rate on new borrowing is by 2 percentage points higher than in the baseline, while grace and maturity periods are the same as in the baseline.

3 / Exports values are assumed to remain permanently at the lower level, but the current account as a share of GDP is assumed to return to its baseline level after the shock (implicitly assuming an offsetting adjustment in import levels).

4/ Includes official and private transfers and FDI.

$5 /$ Depreciation is defined as percentage decline in dollar/local currency rate, such that it never exceeds 100 percent.

6/ Applies to all stress scenarios except for A3 (less favorable financing) in which the terms on all new financing are as specified in footnote 2. 
Figure 1. Grenada: Indicators of Public Sector Debt Under Alternative Scenarios, 2007-27 1/

(In percent)
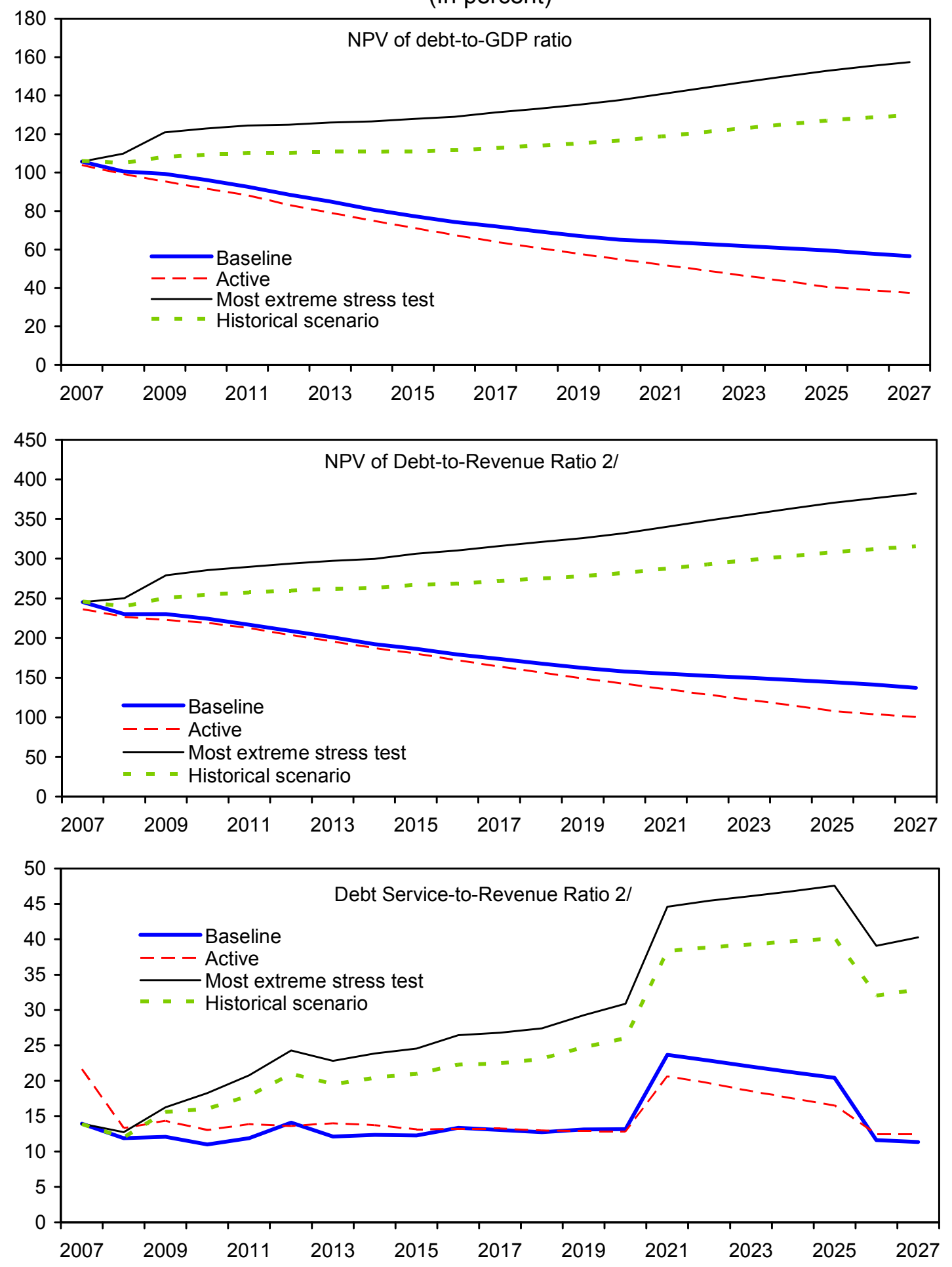

Source: Fund staff projections and simulations.

$1 /$ Most extreme stress test is test that yields highest ratio in 2017.

2/ Revenue including grants. 
Figure 2. Grenada: Indicators of External Debt Under Alternative Scenarios, 2007-27

(In percent)
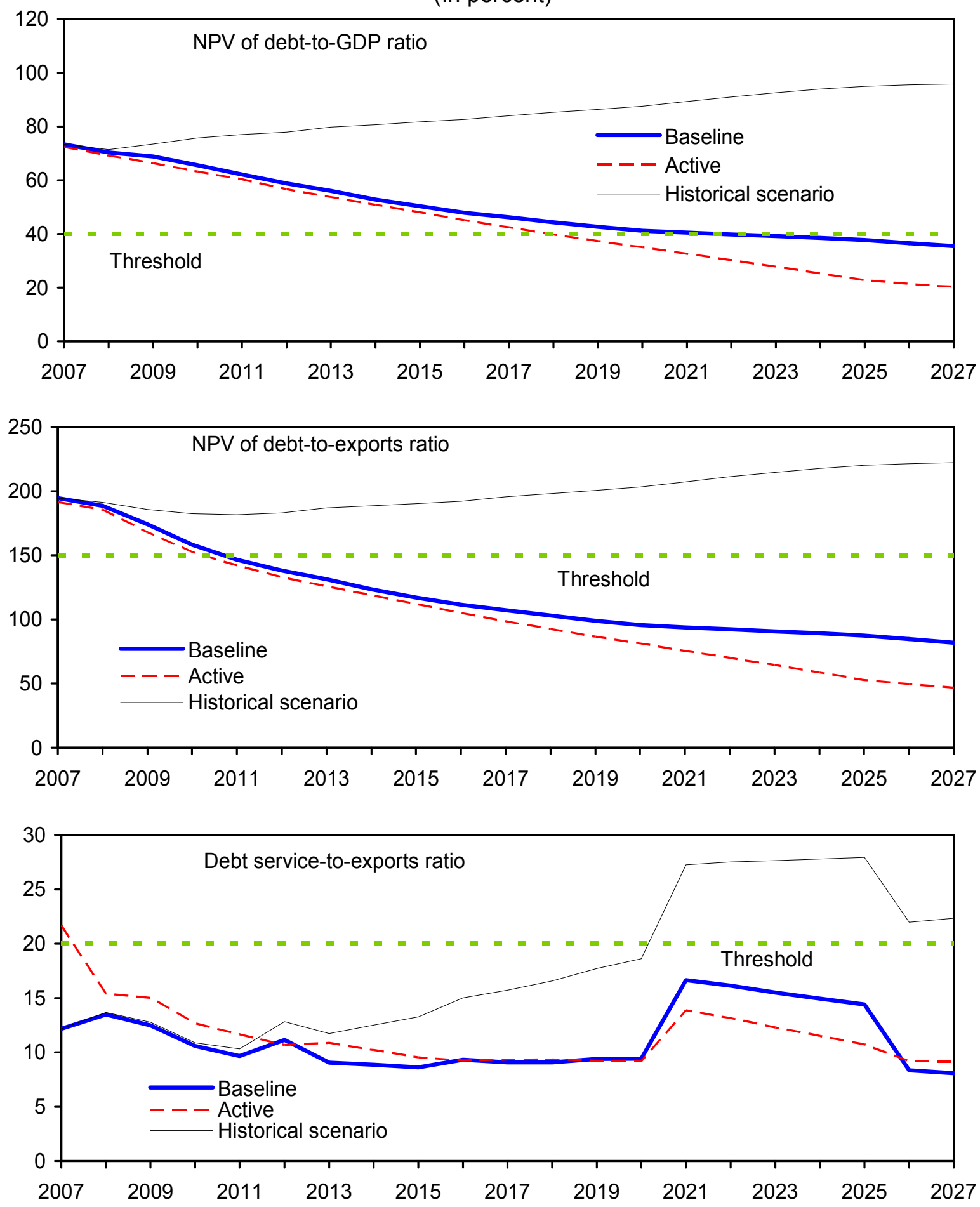

Source: Fund staff projections and simulations. 


\section{INTERNATIONAL MONETARY FUND}

GRENADA

\section{Staff Report for the 2007 Article IV Consultation-Informational Annex}

Prepared by Nancy Wagner, Hunter Monroe, and Pablo Druck

(all Western Hemisphere Department)

September 10, 2007

Contents

Appendices

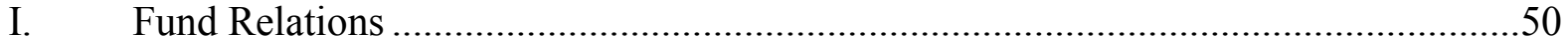

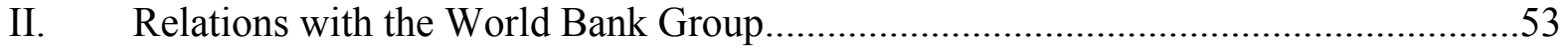

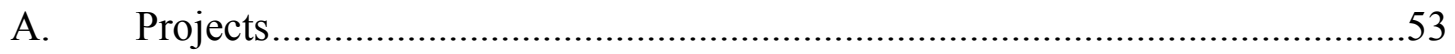

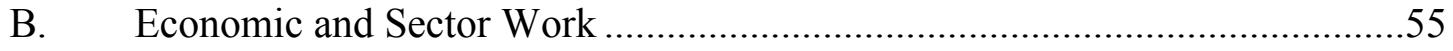

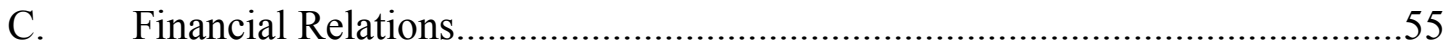

III. Relations with the Caribbean Development Bank ...............................................56

A. New Projects and Technical Assistance ........................................................56

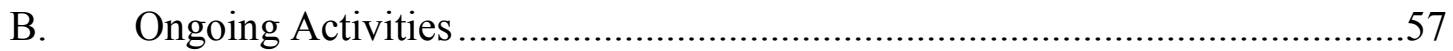

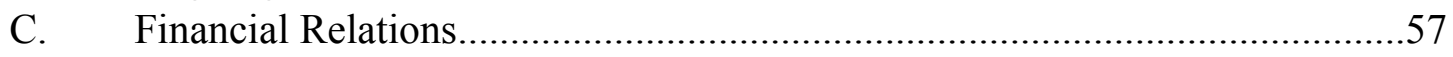

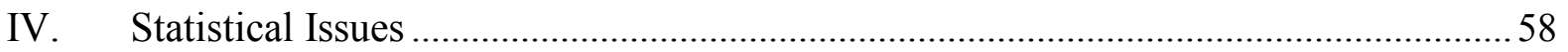

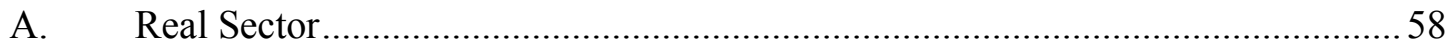

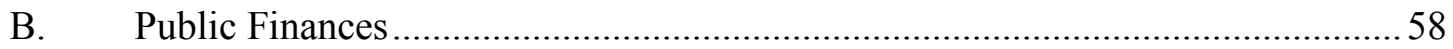

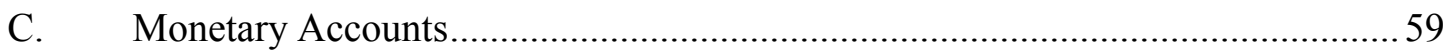

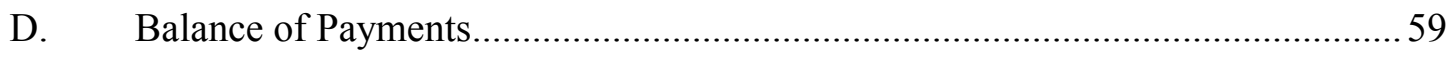

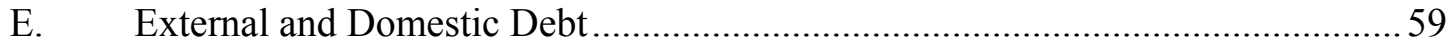


Appendix I. Grenada: Fund Relations

(As of July 31, 2007)

I. Membership Status: Joined: August 27, 1975;

II. General Resources Account:

SDR Million

Quota

11.70

Fund Holdings of Currency

15.36

131.27

Reserve Position

0.00

0.00

III. SDR Department:

SDR Million

Percent of

Net cumulative allocation

0.93

Holdings

0.08

100.00

8.45

Percent of

Quota

Emergency Assistance

3.66

31.26

PRGF Arrangements

1.56

13.33

V. Financial Arrangements:

\begin{tabular}{|c|c|c|c|c|}
\hline Type & $\begin{array}{c}\text { Date of } \\
\text { Arrangement }\end{array}$ & $\begin{array}{l}\text { Expiration } \\
\text { Date }\end{array}$ & $\begin{array}{l}\text { Amount Approved } \\
\text { (SDR Million) }\end{array}$ & $\begin{array}{l}\text { Amount Drawn } \\
\text { (SDR Million) }\end{array}$ \\
\hline$\overline{\text { PRGF }}$ & $\overline{\text { Apr 17, } 2006}$ & Apr $\overline{16,2009}$ & 10.53 & 1.56 \\
\hline
\end{tabular}

VI. Projected Obligations to Fund

(SDR Million; based on existing use of resources and present holdings of SDRs)

\begin{tabular}{lrrrrr} 
& \multicolumn{5}{c}{ Forthcoming } \\
\cline { 3 - 6 } & $\mathbf{2 0 0 7}$ & $\mathbf{2 0 0 8}$ & $\mathbf{2 0 0 9}$ & $\mathbf{2 0 1 0}$ & $\mathbf{2 0 1 1}$ \\
Principal & 0.37 & 1.83 & 1.46 & 0.00 & 0.16 \\
Charges/Interest & 0.13 & 0.19 & 0.10 & 0.05 & 0.04 \\
Total & 0.50 & 2.01 & 1.56 & 0.05 & 0.20
\end{tabular}

\section{Implementation of HIPC and MDRI Initiatives: $\quad$ Not Applicable}

VIII. Safeguards Assessment: Under the Fund's safeguards assessment policy, the Eastern Caribbean Central Bank (ECCB) is subject to a full safeguards assessment under a four-year cycle. The most recent assessment was completed in July 2007, and concluded that the ECCB continues to have appropriate control mechanisms in place, which have strengthened since the first safeguards assessment completed in 2003. ECCB management places emphasis 
on good governance and sound controls, and has enhanced the bank's transparency and accountability since the last assessment, including the publications of financial statements that comply with International Financial Reporting Standards. The assessment made some recommendations to sustain the ECCB's safeguards framework going forward.

IX. Exchange Arrangement: Grenada is a member for the ECCB, which manages monetary policy and the exchange system for its eight members. The common currency, the Eastern Caribbean dollar, has been pegged to the U.S. dollar at the rate of EC $\$ 2.70$ per U.S. dollar since July 1976. In practice, the ECCB has operated like a quasi-currency board, maintaining foreign exchange backing of its currency and demand liabilities of close to 100 percent. Grenada accepted the obligations of Article VIII, Sections 2, 3, and 4 in January 1994. It maintains an exchange system free of restrictions on the making of payments and transfers for current international transactions.

X. Article IV Consultation: Grenada is on the standard 12-month consultation cycle. The last Article IV consultation was concluded by the Executive Board on July 13, 2005 (IMF Country Report No. 05/290).

XI. FSAP Participation: Grenada participated in the regional Eastern Caribbean Currency Union FSAP conducted in September and October 2003. The Financial System Stability Assessment is IMF Country Report No. 04/293.

\section{Technical Assistance:}

\section{Caribbean Regional Technical Assistance Centre (CARTAC)}

CARTAC has provided wide-ranging assistance in developing a Medium-Term Macroeconomic Framework (as part of the Structural Adjustment Technical Assistance Program); preparing to implement a VAT, building upon previous work, including draft VAT/excise laws (prepared by LEG) and a VAT sensitivity study and training/publicity tasks (undertaken with CARTAC/FAD assistance); assisting customs with ASYCUDA/ASYCUDA++ and with the exchange of information with inland revenue; drafting legislation to establish the single supervisory agency, Grenada Authority for the Regulation of the Financial Institutions (GARFIN) and supporting the newly established agency; and training for nonbank supervisors. CARTAC has also provided substantial assistance in improving the production and dissemination of macroeconomic statistics, including national accounts compilation; rebasing of the consumer price index; initiating work to prepare export-import price indices; training in the processing of trade data; and improving external sector statistics as part of a major CARTAC/ECCB project. 


\section{Other Technical Assistance (2006-07):}

FAD and LEG have provided extensive assistance in tax policy and administration. In particular, FAD and LEG have assisted in the design and drafting of a VAT and related changes to excise taxes. LEG has also assisted with training for tax officials and with the finalization of the VAT and excise laws. A series of FAD missions have provided further assistance on implementing a VAT and on tax and customs administration more broadly. 


\title{
Appendix II. Grenada: Relations with the World Bank Group
}

\author{
(As of April 30, 2007)
}

In September 2005, the Eastern Caribbean Sub-Region Country Assistance Strategy (CAS) for FY 2006-09 was presented to the Board of the World Bank. The strategy supports the sub-region's development agenda through two main pillars: (1) stimulating growth and improving competitiveness; and (2) reducing vulnerability, by promoting greater social inclusion and strengthening disaster risk management. Recognizing the Organization of Eastern Caribbean States (OECS) countries' weakened creditworthiness due to high debt ratios, Bank activities will focus on leveraging available donor grant financing. Following the recommendations of the recently completed growth and competitiveness study for the OECS, IBRD and IDA support would focus on providing technical and financial assistance for interventions to support the two main pillars. An indicative Base Case lending scenario consists of about US\$51.3 million in IDA resources for the four OECS blend countries (Dominica, Grenada, St. Lucia, and St. Vincent and the Grenadines). This amount includes the estimated IDA country allocations for each of the four countries during FY 2006-09, and an IDA Regional allocation of US\$15.2 million for two regional projects: US\$12 million for Catastrophe Risk Insurance and US\$3.2 million for Infrastructure and Utilities Reform.

\section{A. Projects}

There are six active World Bank projects in Grenada for a net commitment of approximately US\$42.35 million.

The Telecommunications and ICT Development Project, approved in May 2005 for US\$540,000, aims at improving the access, quality, and use of telecommunications and ICT services to achieve socio-economic development in the OECS. The project has the following four components: Component (1) will strengthen the national and regional regulatory frameworks and promote additional competition in the telecommunications sector. Component (2) will review current universal access policy, create related guidelines, and provide financial support to establish a Universal Service Fund (USF). Component (3) will improve growth and competitiveness in ICT-enabled services through utilization of broadband infrastructure. Component (4) will ensure management and administration of the overall project.

The Public Sector Modernization Technical Assistance Project, approved in December 2005 for US\$3.5 million, supports the Government of Grenada in the process of modernizing its public sector. The project has the following components: Component(1) will finance: (i) the strategic review of the proposed organizations and functions for conversion to Executive Agencies status; (ii) the preparation of detailed, modernization and financing plans for each conversion; (iii) the preparation of a Policy Framework for Executive Agencies; and 
(iv) the preparation of enabling legislation - including the preparation of a draft Executive Agencies bill to be presented to Cabinet and Parliament under Grenada's legal framework. Component (2) will support the strengthening of the Small Business Development Centre (SBDC) of the Grenada Industrial Development Corporation (GIDC) that will provide technical assistance and training to the micro/small segment of the business community. Component (3) will support Grenada in taking the lead to jointly procure select goods and services with other OECS countries. Component (4) will strengthen the Public Sector Reform Unit by providing financial and technical resources and training in key policy areas.

The Grenada Education Reform Project, approved in June 2003 for US $\$ 8.0$ million, is a follow-up to an earlier education project. Its goal is to build human capital, with a view to contributing to economic diversification and more sustainable growth. Key objectives are to: (i) increase equitable access to secondary education; (ii) improve the quality of the teaching and learning processes, with more direct interventions at the school level and an increased focus on student-centered learning, and (iii) strengthen management of the education sector and to improve governance of schools.

The HIV/AIDS Prevention and Control Program, approved in July 2002 for US\$6.04 million, is funded under the Multi-Country APL for the Caribbean Region. Its objectives are to: (i) curb the spread of the HIV/AIDS pandemic; (ii) reduce the morbidity and mortality attributed to HIV/AIDS; (iii) improve the quality of life for persons living with HIV/AIDS; and (iv) develop a sustainable organizational and institutional framework for managing the HIV/AIDS epidemic. The Bank's support to Grenada under this project amounts to US\$6.0 million.

The Hurricane Ivan Emergency Project was approved in November 2004 for US\$10 million, with an additional US\$9.8 million added in September 2005. This emergency assistance for Grenada was implemented to respond to the effects of a devastating hurricane that hit the island in September 2004. The project supports the recovery efforts of the Government of Grenada through the financing of critical imports and rehabilitation activities in key social sectors.

The Caribbean Catastrophe Risk Insurance Facility (CCRIF) was approved in January 2007. This is the world's first ever multi-country catastrophe insurance pool. The bank has approved a US\$4.5 million IDA credit for Grenada to finance their contribution to the fund over three years. The Facility will enable governments to purchase catastrophe insurance coverage against adverse natural events, such as a major earthquake or hurricane. The CCRIF allows participating countries to pool their country-specific risks into one, betterdiversified portfolio, resulting in a substantial reduction in the premium cost. 


\section{B. Economic and Sector Work}

The Bank has completed a series of analytical work relating to: public sector capacity in the OECS including the Institutional and Organizational Capacity Review, the OECS Procurement Assessment Review, and the OECS Financial Accountability Assessment. In conjunction with the IMF, a Financial Sector Assessment Program (FSAP) was completed in early 2004. The Bank also recently completed an OECS study on Growth and Competitiveness, a Caribbean Air Transport Rationalization Report and a report on Crime, Violence and Development: Trends, Cost and Policy Options in the Caribbean. Work is ongoing on an OECS Private Sector Financing Study, and a Caribbean Skills and Curriculum Study.

\section{Financial Relations}

(In millions of U.S. dollars)

\begin{tabular}{|l|c|c|c|}
\hline Operation & $\begin{array}{c}\text { Original } \\
\text { Principal }\end{array}$ & Available $^{\mathbf{1}}$ & Disbursed $^{\mathbf{1}}$ \\
\hline Telecommunications \& ICT Development Project & 0.54 & 0.46 & 0.11 \\
\hline $\begin{array}{l}\text { Public Sector Modernization Technical Assistance } \\
\text { Credit }\end{array}$ & 3.50 & 3.45 & 0.36 \\
\hline Grenada Education Reform Project & 8.00 & 5.39 & 3.02 \\
\hline HIV/AIDS Prevention And Control Program & 6.04 & 5.80 & 0.85 \\
\hline Hurricane Ivan Emergency Recovery Project & 19.77 & 12.41 & 7.69 \\
\hline The Caribbean Catastrophe Risk Insurance & 4.50 & 4.50 & 0.00 \\
\hline Total & $\mathbf{4 2 . 3 5}$ & $\mathbf{3 2 . 0 1}$ & $\mathbf{1 2 . 0 3}$ \\
\hline
\end{tabular}

${ }^{1}$ Amounts may not add up to Original Principal due to changes in the SDR/US exchange rate since signing.

Disbursements and Debt Service (Calendar Year)

\begin{tabular}{|l|c|c|c|c|c|c|c|c|c|c|}
\hline & $\mathbf{1 9 9 8}$ & $\mathbf{1 9 9 9}$ & $\mathbf{2 0 0 0}$ & $\mathbf{2 0 0 1}$ & $\mathbf{2 0 0 2}$ & $\mathbf{2 0 0 3}$ & $\mathbf{2 0 0 4}$ & $\mathbf{2 0 0 5}$ & $\mathbf{2 0 0 6}$ & $\mathbf{2 0 0 7 *}$ \\
\hline Total disbursements & & & & & & & & & & \\
& 0.92 & 1.74 & 2.64 & 1.25 & 6.87 & 3.79 & 2.91 & 6.38 & 3.99 & 1.11 \\
\hline Repayments & 0.07 & 0.06 & 0.07 & 0.06 & 0.07 & 0.10 & 0.39 & 0.77 & 1.45 & 0.72 \\
\hline Net disbursements & 0.85 & 1.67 & 2.58 & 1.19 & 6.80 & 3.69 & 2.52 & 5.61 & 2.54 & 0.39 \\
\hline Interest and fees & 0.06 & 0.05 & 0.13 & 0.30 & 0.33 & 0.42 & 0.53 & 0.60 & 0.73 & 0.34 \\
\hline
\end{tabular}

* Figures as of April 30, 2007 


\section{Appendix III. Grenada: Relations with the Caribbean Development Bank}

(As of May 2, 2007)

\section{A. New Projects and Technical Assistance}

Grenada continued to receive special financing from the Caribbean Development Bank (CDB) for projects intended to facilitate the recovery and reconstruction process; to build capacity; and to assist with poverty reduction. The financing apportioned to Grenada incorporates a blend of the Bank's Special Development Funds (SDF) and ordinary capital resources, designed to yield a concessionary grant element of 35 percent. The SDF, administered exclusively for high-priority development loans, offer loans with longer maturities and grace periods, as well as lower interest rates than those applied in the Bank's ordinary operations.

\section{Grenville Market Square Development Project}

In 2006, an investment loan of US\$11 million was approved to assist in the development of Grenville Town as the main urban centre serving the island's northern and eastern coasts. The market square will be renovated and a new abattoir and bus terminus will be provided.

\section{Project Management Training}

Grenada benefited from two training programmes to improve project administration capacity. Country participants took part, along with other Caribbean countries, in an extensive, regional training programme, which emphasizes quality project design and efficient project execution.

The Government of Grenada also benefited from a one week in-country training workshop on Cost-Benefit Analysis. The training provided participants with the tools and techniques required for the identification, preparation and initial screening and prioritization of project proposals for inclusion in the Public Sector Investment Programme (PSIP). It enabled participants to establish the link between individual project proposals and macroeconomic objectives; prepare initial project proposals; and understand and apply the tools and techniques of Financial, Economic, and Uncertainty and Risk Analysis, and interpret results.

\section{Country Poverty Assessment}

The Government of Grenada launched its CDB-supported Country Poverty Assessment (CPA) in February 2007. Financed by a technical assistance grant of US\$355,000, this assessment will provide quantitative poverty data garnered from the conduct of a National Survey of Living Conditions to be used to update the critical or indigent poverty line, and the absolute poverty line. CPAs also assess the current conditions affecting the welfare of the poor, identifies policies, strategies and programmes that would sustainably reduce the extent 
and severity of poverty. Through a highly participatory process, the CPA incorporates the use of qualitative participatory techniques (such as focus groups, stakeholder, community and national consultations) to provide insights on living conditions and coping strategies of marginalized communities and vulnerable groups. These are critical inputs for the preparation of Grenada's Poverty Reduction Strategy. Grenada's last CPA was conducted in 1998.

\section{B. Ongoing Activities}

Loan disbursements continued for projects under implementation. These included capital works to upgrade and rehabilitate physical infrastructure including the road and bridge network, and to reduce the risk of rock fall and landslip events in the aftermath of natural hazards. Disbursements were also directed for debt support to assist the government in meeting its financial obligations, as well as to improve the shelter conditions of low-income households through the provision of 116 serviced lots at two sites-Soubise and Mount Gay. These form part of government's long-term programme of housing and human settlement recovery and reconstruction in Grenada.

\section{Financial Relations}

(As of December 31, 2006; in millions of U.S. dollars)

\begin{tabular}{|c|c|c|c|c|c|}
\hline Item & 2002 & 2003 & 2004 & 2005 & 2006 \\
\hline Cumulative total credit approved ${ }^{1}$ & 112.8 & 120.7 & 143.8 & 169.0 & 180.1 \\
\hline Cumulative disbursements $^{2}$ & 88.6 & 97.0 & 99.7 & 112.8 & 130.0 \\
\hline \multicolumn{6}{|c|}{ Disbursements } \\
\hline Ordinary Capital Resources & 1.0 & 4.7 & 5.8 & 5.6 & 3.3 \\
\hline Special Development Fund & 2.5 & 4.3 & 3.9 & 8.4 & 9.8 \\
\hline Other Special Fund Resources & 1.4 & 0.1 & 0.1 & 0.6 & 3.9 \\
\hline \multicolumn{6}{|c|}{ Amortization $^{3}$} \\
\hline Ordinary Capital Resources & 0.7 & 0.8 & 0.3 & 1.2 & 1.5 \\
\hline Special Development Fund & 1.7 & 1.7 & 1.7 & 1.6 & 1.6 \\
\hline Other Special Fund Resources & 0.2 & 0.2 & 0.2 & 0.2 & 0.3 \\
\hline Outstanding debt (end of period) & 55.7 & 61.2 & 67.1 & 77.6 & 91.6 \\
\hline \multicolumn{6}{|c|}{ Interest and Commitment Fees } \\
\hline Ordinary Capital Resources & 1.1 & 1.1 & 1.3 & 1.6 & 1.9 \\
\hline Special Development Fund & 0.7 & 0.6 & 0.6 & 0.7 & 0.9 \\
\hline Other Special Fund Resources & 0.2 & 0.2 & 0.2 & 0.2 & 0.2 \\
\hline
\end{tabular}

Source: Caribbean Development Bank.

\footnotetext{
1 Loans and grants.

${ }^{2}$ Including valuation adjustments.

${ }^{3}$ Ordinary capital resources (OCR) are loans on nonconcessional terms. Special development funds (SDF) and other special fund (OSF) resources are soft loans. Commitment fees apply only to OCR.
} 


\section{Appendix IV. Grenada: Statistical Issues}

Since March 2001, Grenada has participated in the Fund's General Data Dissemination System (GDDS). Its metadata are posted on the Dissemination Standards Bulletin Board, although these have not been certified and updated recently. The metadata include short- and medium-term plans for statistical development. Improvement in several key areas are needed to facilitate effective surveillance. Some of the outstanding issues are detailed below.

\section{A. Real Sector}

There are a number of deficiencies in the real sector statistics. National accounts are provided annually. However, GDP by expenditure is available only with long lags, and real GDP by sector is not available. The estimation of gross capital formation needs to be improved and sectoral price deflators computed. There are discrepancies in the foreign trade estimates prepared by the customs department and the Central Statistical Office (CSO), and coverage, consistency, and timeliness of tourism data are limited.

Consumer prices are the only real sector data provided between missions. The basket used to compute the consumer price index was last updated in 2000. A producer price index is not available.

Labor statistics are limited and outdated, with 1998 being the most recent year for which data are available. There are no regular wage and unemployment data. Data collected during the 2001 population census are still being processed. The CSO is working with the International Labor Organization (ILO) to improve the coverage of labor market statistics.

\section{B. Public Finances}

The reporting of central government data has improved in recent years, with quarterly data being provided to the ECCB, WHD, and other users in Fund economic classification format with lags of about two months. However, there appear to be inaccuracies in the composition of public expenditure. Moreover, capital expenditures could include current expenditure items, and the nature of expenditures in the Public Sector Improvement Program needs to be scrutinized carefully. In addition, spending on outsourced activities is not broken down into the appropriate categories, but rather grouped into a single category.

The coverage of the rest of the public sector is very limited, and there are no consolidated public sector accounts. There is no systematic reporting of information to the ministry of finance. Annual statements for some public enterprises are provided during Fund missions. It would be useful to institute a mechanism for the regular reporting of financial data pertaining to the rest of the public sector.

The authorities do not report fiscal data for publication in IFS. Grenada has not provided any fiscal data, either on a GFSM 2001 basis, or a cash basis, for presentation in the 
GFS Yearbook. The ECCB disseminates Grenada's quarterly GFS data in its Economic and Financial Review.

\section{Monetary Accounts}

The ECCB compiles monthly data on depository corporations (central bank and other depository corporations) and reports the accounts attributable to Grenada to STA using the standardized report forms with a lag of about two months for publication in the IFS and the IFS Supplement. The ministry of finance does not collect data regularly on finance companies, building societies, and credit unions, which also accept deposits, and on other financial corporations; this may improve with the formation of the Grenada Authority for the Regulation of Financial Institutions.

Expanding institutional coverage to include all depository corporations and the other financial corporations, such as credit unions and insurance companies, would enhance understanding of savings and credit as well as improve compilation of monetary aggregates. In addition, improved classification of financial instruments and loan categorization would enhance identification of credit flows to different sectors of the economy.

\section{Balance of Payments}

The ECCB compiles and reports balance of payments statistics on an annual basis, using information collected by the CSO. The latest data published in the IFS and Balance of Payments Yearbook are for 2005. Incomplete, provisional data have been produced for 2006 by the ECCB. These will be completed and finalized later this year or early in 2008 .

Many of these statistics are based on information collected from surveys, and are not comprehensive. Trade statistics have traditionally been more reliable and available by SITC classification on a quarterly basis. However, reliability and detail of trade statistics have suffered considerably in the aftermath of Hurricane Ivan (September 2004) and reporting is not yet fully back on track.

Enhanced data sources and better compilation procedures are needed to improve the accuracy of balance of payments statistics. Moreover, quarterly balance of payments statistics and international investment position data are not compiled.

\section{E. External and Domestic Debt}

The database for government external debt is quite comprehensive, and can be used to provide detailed and reasonably up-to-date breakdowns of disbursements and debt service. However, data availability on domestic debt, government-guaranteed debt, and debt of public enterprises is limited, and there is no data on private external debt. 


\section{GRENADA: TABLE OF COMMON INDICATORS REQUIRED FOR SURVEILLANCE}

AS OF SEPTEMBER 7, 2007

\begin{tabular}{|c|c|c|c|c|c|}
\hline & $\begin{array}{c}\text { Date of } \\
\text { latest } \\
\text { observation }\end{array}$ & $\begin{array}{l}\text { Date } \\
\text { received }\end{array}$ & $\begin{array}{c}\text { Frequency } \\
\text { of } \\
\text { Data }^{1}\end{array}$ & $\begin{array}{l}\text { Frequency of } \\
\text { Reporting }\end{array}$ & $\begin{array}{l}\text { Frequency of } \\
\text { publication }\end{array}$ \\
\hline Exchange Rates ${ }^{2}$ & NA & NA & NA & NA & NA \\
\hline International Reserve Assets and Reserve Liabilities of the Monetary Authorities ${ }^{3}$ & Jul 2007 & $9 / 7 / 07$ & M & M, with 2- to 3-month lag & $\mathrm{A} / \mathrm{Q}$ \\
\hline Reserve/Base Money & Jul 2007 & $9 / 7 / 07$ & M & M, with 2- to 3-month lag & $\mathrm{A} / \mathrm{Q}$ \\
\hline Broad Money & Jul 2007 & $9 / 7 / 07$ & M & M, with 1- to 2-month lag & $\mathrm{A} / \mathrm{Q}$ \\
\hline Central Bank Balance Sheet & Jul 2007 & $9 / 7 / 07$ & M & M, with 1- to 2-month lag & $\mathrm{A} / \mathrm{Q}$ \\
\hline Consolidated Balance Sheet of the Banking System & Jul 2007 & $9 / 7 / 07$ & M & M, with 2- to 3-month lag & $\mathrm{A} / \mathrm{Q}$ \\
\hline Interest Rates ${ }^{4}$ & Jul 2007 & $9 / 7 / 07$ & M & M, with 1- to 2-month lag & $\mathrm{A} / \mathrm{Q}$ \\
\hline Consumer Price Index & May 2007 & Aug 2007 & M & M, with 1- to 2-month lag & $\mathrm{A} / \mathrm{M}$ \\
\hline Revenue, Expenditure, Balance and Composition of Financing ${ }^{5}-$ Central Government & Jun 2007 & Jul 2007 & M & Q, with 1- to 2-month lag & A \\
\hline Stocks of Central Government and Central Government-Guaranteed Debt ${ }^{6}$ & Jun 2007 & Jul 2007 & $\mathrm{M} / \mathrm{A}$ & Q, with 1- to 2-month lag & A \\
\hline External Current Account Balance & Dec 2006 & Jul 2006 & A & Article IV Mission & A \\
\hline Exports and Imports of Goods and Services & Dec 2006 & Jul 2006 & A & Article IV Mission & A \\
\hline GDP/GNP & Dec 2006 & Jul 2006 & A & Article IV Mission & A \\
\hline Gross External Debt ${ }^{7}$ & Jul 2007 & Aug 2007 & Q & Q, with 1- to 2-month lag & A/Semi-annual \\
\hline
\end{tabular}

${ }^{1}$ Daily (D), Weekly (W), Monthly (M), Quarterly (Q), Annually (A); Irregular (I); Not Available (NA).

${ }^{2}$ Grenada is a member of the Eastern Caribbean Currency Union, in which the common currency of all member states (EC dollar) has been pegged to the U.S. dollar at US\$1=EC\$2.70 since July 1976.

${ }^{3}$ Includes reserve assets pledged or otherwise encumbered as well as net derivative positions.

${ }^{4}$ Both market-based and officially-determined, including discount rates, money market rates, rates on treasury bills, notes and bonds.

${ }^{5}$ Foreign, domestic bank, and domestic nonbank financing.

${ }^{6}$ Including currency and maturity composition.

${ }^{7}$ Public external debt only. 


\title{
INTERNATIONAL MONETARY FUND
}

Public Information Notice

EXTERNAL

RELATIONS

DEPARTMENT

Public Information Notice (PIN) No. 07/132

FOR IMMEDIATE RELEASE

October 25, 2007

\author{
International Monetary Fund \\ $70019^{\text {th }}$ Street, NW \\ Washington, D. C. 20431 USA
}

\section{IMF Executive Board Concludes 2007 Article IV Consultation with Grenada}

On September 26, 2007, the Executive Board of the International Monetary Fund (IMF) concluded the Article IV consultation with Grenada. ${ }^{1}$

\section{Background}

Grenada's economy has rebounded after the devastating impact of Hurricanes Ivan and Emily, with the recovery centered on reconstruction and 2007 Cricket World Cup (CWC) preparations. Real GDP growth averaged 7 percent a year during 2005-06 and is projected at about 3 percent in 2007 and 4 percent beyond, reflecting a further strengthening of tourism, the recent initiation of several major tourism projects, and a gradual recovery of agriculture. Inflation has remained low, buttressed by the regional currency board arrangement.

The external current account deficit improved slightly in 2006, with rising tourism receipts nearly offsetting the tapering off of large insurance payouts in 2005. The deficit is expected to remain large, at over 20 percent of GDP over the near term, mainly financed by foreign direct investment and capital grants. In particular, there has been a substantial increase in foreign direct investment in the tourism sector. External competitiveness appears to have improved recently, but fiscal adjustment and enhancing the investment climate will be important to sustaining competitiveness over the longer term.

Monetary and financial developments have been favorable. Growth in credit to the private sector, which had declined sharply after Hurricane Ivan, picked up pace in 2006. Grenada's banking

\footnotetext{
${ }^{1}$ Under Article IV of the IMF's Articles of Agreement, the IMF holds bilateral discussions with members, usually every year. A staff team visits the country, collects economic and financial information, and discusses with officials the country's economic developments and policies. On return to headquarters, the staff prepares a report, which forms the basis for discussion by the Executive Board. At the conclusion of the discussion, the Managing Director, as Chairman of the Board, summarizes the views of Executive Directors, and this summary is transmitted to the country's authorities.
} 
system is resilient, having weathered the hurricanes well. While there was a temporary increase in the share of nonperforming loans following Hurricane Ivan, unsatisfactory assets have since been steadily declining, with the share falling below pre-hurricane levels. Grenada also established a single regulatory agency to strengthen supervision of nonbank financial institutions.

Large fiscal slippages in 2006-07 have slowed the pace of restoring fiscal and debt sustainability. Despite revenue-enhancing measures, capital expenditure overruns (owing to higher-thananticipated costs for reconstruction and CWC preparations) led to much higher fiscal deficits than targeted. As a result, public debt rose, reaching 125 percent of GDP at end-2006, leaving little room for maneuver in the event of future shocks. On current policies, the overall deficit (including grants) this year would be about 31/4 percent of GDP, compared with almost 7 percent in 2006. Absent more active and front-loaded fiscal adjustment, the authorities' debt-to-GDP target of 60 percent might not be achieved until well after 2020, the Eastern Caribbean Central Bank's regional target date.

Implementation of the structural reform agenda has been uneven. Solid progress has been made with fiscal measures, including the introduction of the National Reconstruction Levy, the adoption of an automatic fuel pricing mechanism, strengthened collection of tax arrears, and work toward implementing a VAT. Important steps have also been taken to reduce vulnerabilities, such as participating in the Caribbean Catastrophe Risk Insurance Facility and taking steps toward giving the Building Code force of law. Other structural reforms have suffered delays, including legislative action to reform the tax concessions regime, creating a one-stop shop for investors, strengthening the capacity to evaluate and prioritize capital projects, and modernizing the public sector.

The government's highly successful debt restructuring is now largely complete and has resulted in substantial debt service savings. The authorities have continued good-faith efforts to pursue debt restructuring agreements with the few remaining nonparticipating creditors.

\section{Executive Board Assessment}

Directors welcomed Grenada's strong economic rebound in the aftermath of hurricane devastation and the broadly favorable economic prospects, with major tourism investments under way and the gradual recovery of the agricultural sector. At the same time, substantial challenges remain, in particular the weak fiscal position and high debt levels, which erode the room for maneuver in the event of further external shocks. The debt situation would remain unsustainable if current fiscal policies were continued. Against that background, Directors agreed that the authorities' home-grown reform program focuses appropriately on achieving fiscal and debt sustainability, durable high growth, poverty alleviation, and the mitigation of vulnerabilities.

Directors welcomed the steps that have been taken by the authorities to place Grenada's fiscal position on a more solid footing, including the implementation of an automatic mechanism for setting fuel prices and a broadly-based National Reconstruction Levy. They noted, however, that further fiscal consolidation will be key to placing debt on a sustainable trajectory. Spending restraint will be needed, including on capital expenditure and the public sector wage bill. The expected divestment proceeds should be used to pay down expensive debt, rather than to 
finance additional budgetary expenditures. Directors called on the authorities to explore a regional solution to the current counter-productive tax abatement competition among Caribbean countries.

Directors encouraged the authorities to strengthen public financial management and adopt multi-year budgeting. They recommended clearing arrears as soon as possible, avoiding reliance on unsustainable financing, and enhancing capital project evaluation capacity. They welcomed the authorities' intention to introduce a VAT, and encouraged them to move forward expeditiously in line with their implementation schedule. A track record of budgetary discipline would help boost investor confidence, which will be critical to maintain credit market access and foreign direct investment flows. Directors noted that technical assistance from the Fund in the areas of debt management and the budget could be useful.

Directors considered that external competitiveness appears adequate, with Grenada's share of the regional tourism market increasing. Fiscal consolidation will help sustain competitiveness and support the regional currency board arrangement.

Directors commended the authorities for strengthening the financial system's supervisory framework, as evidenced by the establishment of a single regulatory agency for nonbank institutions. They supported plans to address regulatory gaps in the insurance sector and bring all nonbank financial entities under the regulatory agency's oversight. Directors called on the authorities to bring the unregulated commercial bank under proper supervision without delay.

Directors welcomed the efforts being made by the authorities to enhance the business climate and improve competitiveness, including through the recently developed national export strategy, the one-stop shop being established for investors, and other measures to reduce business costs. They encouraged the authorities to accelerate the implementation of these and other aspects of their structural reform agenda, including moving ahead with reforms to arrangements governing tax concession.

Directors welcomed the steps taken to strengthen enforcement of the building code and enact a new Insurance Act, which will help mitigate vulnerabilities.

Directors encouraged the authorities to further strengthen the coverage, quality, and timeliness of the statistical database to support policy analysis, surveillance, and public debate.

Directors encouraged the authorities to work toward completion of the pending first review under the Poverty Reduction and Growth Facility (PRGF) arrangement-by taking corrective action on the fiscal front, addressing the issue of the unregulated bank, and accelerating the pace of structural reform. These steps would unlock additional financial resources and help lay the foundation for strong, sustainable growth in the years ahead.

Public Information Notices (PINs) form part of the IMF's efforts to promote transparency of the IMF's views and analysis of economic developments and policies. With the consent of the country (or countries) concerned, PINs are issued after Executive Board discussions of Article IV consultations with member countries, of its surveillance of developments at the regional level, of post-program monitoring, and of ex post assessments of member countries with longer-term program engagements. PINs are also issued after Executive Board discussions of general policy matters, unless otherwise decided by the Executive Board in a particular case. 
Grenada: Selected Economic Indicators

\begin{tabular}{llllll} 
& & & Prog. 1/ Prel. & Proj. \\
\cline { 1 - 2 } & 2003 & 2004 & 2005 & $2006 \quad 2007$ \\
\hline
\end{tabular}

\section{Output and prices}

(Annual percentage change, unless otherwise specified)

\section{Real GDP}

GDP deflator

Consumer prices (end of period)

Money and credit 2/

Net foreign assets of the banking system

Net domestic assets of the banking system

Of which

Net credit to the nonfinancial public sector

Credit to the private sector

Liabilities to the private sector (M2)

Balance of payments

Merchandise exports, f.o.b.

Merchandise imports, c.i.f.

Real effective exchange rate (end of period, depreciation -)

Current account balance (in percent of GDP)

$\begin{array}{rrrrrr}6.4 & -6.5 & 12.7 & 6.5 & 0.7 & 3.0 \\ 0.9 & 4.2 & 2.9 & 4.6 & 3.0 & 2.4 \\ 1.6 & 2.5 & 5.8 & 2.0 & 1.7 & 2.0 \\ & & & & & \\ 5.8 & 17.9 & -19.3 & -2.2 & -6.4 & 0.0 \\ 2.2 & -0.2 & 18.3 & 10.1 & 7.3 & 3.9 \\ & & & & & \\ 2.3 & -6.5 & -1.1 & 0.0 & 0.2 & -1.5 \\ 3.1 & 5.0 & 6.2 & 8.5 & 9.2 & 4.6 \\ 8.0 & 17.7 & -1.0 & 7.8 & 0.9 & 3.9 \\ & & & & & \\ 10.0 & -18.9 & -5.5 & 0.6 & -15.6 & 14.5 \\ 25.1 & 3.9 & 20.0 & -3.4 & -8.0 & 5.0 \\ -5.2 & -3.5 & 5.6 & \ldots & -4.6 & \ldots \\ -32.2 & -12.4 & -24.9 & -32.8 & -23.9 & -24.9\end{array}$

\section{Central government finances $\mathbf{3 /}$}

Total revenue and grants

Of which

\section{Grants}

Current expenditure

Capital expenditure

Primary balance (excluding grants)

Overall balance (including grants)

Nonfinancial public sector debt (gross)

Total

Of which

External

Memorandum items:

Nominal GDP

Gross international reserves of the ECCB; end-of-period

(In percent of GDP, unless otherwise specified)

Sources: Grenada authorities; ECCB; and Fund staff estimates and projections

1/ IMF Country Report No. 06/277, Request for PRGF (July 2006).

$2 /$ As a percent of broad money at the beginning of the year.

3/ Measured using above-the-line information.

$\begin{array}{rrrrrr}34.4 & 33.4 & 37.6 & 36.1 & 36.1 & 31.1 \\ & & & & & \\ 6.9 & 7.5 & 11.3 & 8.0 & 9.3 & 2.7 \\ 24.3 & 28.2 & 22.1 & 22.7 & 22.8 & 23.7 \\ 14.9 & 8.0 & 15.0 & 15.4 & 20.2 & 10.7 \\ -6.5 & -3.9 & -8.7 & -7.7 & -13.9 & -3.4 \\ -4.8 & -2.8 & 0.5 & -2.0 & -6.8 & -3.2 \\ & & & & & \\ 109.6 & 130.7 & 120.2 & 118.9 & 125.4 & 115.1 \\ & & & & & \\ 79.9 & 96.0 & 86.0 & 88.4 & 87.1 & 82.7 \\ \text { dollars) } & & & & & \\ & & & & & \\ 445.3 & 433.0 & 508.2 & 519.3 & 524.9 & 554.3 \\ 539.9 & 632.4 & 600.8 & \ldots & 696.0 & \ldots\end{array}$

